Molecules 2003, 8, 793-865

molecules

ISSN 1420-3049

http://www.mdpi.org

\title{
Review
}

\section{The Chemistry of $\alpha$-Haloketones and Their Utility in Heterocyclic Synthesis}

\author{
Ayman W. Erian ${ }^{1, *}$, Sherif M. Sherif ${ }^{1}$ and Hatem M. Gaber ${ }^{2}$ \\ ${ }^{1}$ Department of Chemistry, Faculty of Science, Cairo University, Giza, Egypt \\ ${ }^{2}$ National Organization for Drug Control and Research (NODCAR), P.O. Box 29, Cairo, Egypt; \\ E-mail: hatemgaber@yahoo.com
}

*Author to whom correspondence should be addressed; E-mail: erian11@hotmail.com

Received: 21 June 2003; in revised form: 15 August 2003 / Accepted: 18 August 2003 / Published 15 Noember 2003

\begin{abstract}
The molecular structures and spectral properties of $\alpha$-haloketones as well as their syntheses are analyzed and reviewed. Their reactivity towards oxygen, nitrogen, and sulfur nucleophiles, carboxylic acids, carbon nucleophiles, alkenes, and alkynes are discussed.
\end{abstract}

Keywords: $\alpha$-Haloketones; annelated heterocycles; oxygen nucleophiles; nitrogen nucleophiles; sulfur nucleophiles; carbon nucleophiles.

\section{Contents}

I. Introduction

II. Molecular Structures and Spectral Properties

III. Synthesis of $\alpha$-Haloketones
A. General Methods
B. Miscellaneous Halogenating Agents

IV. Chemical Reactivity 
V. Reactions of $\alpha$-Haloketones with Oxygen, Nitrogen and Sulfur Nucleophiles

A. Synthesis of Five-Membered Rings with One Heteroatom

1. Furans and Their Fused Derivatives

2. Pyrroles and Their Fused Derivatives

3. Thiophenes and Their Fused Derivatives

B. Synthesis of Five-Membered Rings with with Two Heteroatoms

1. Imidazoles and Their Fused Derivatives

2. Thiazoles and Their Fused Derivatives

C. Synthesis of Five-Membered Rings with Two or Three Miscellaneous Heteroatoms

D. Synthesis of Six-Membered Rings with One Heteroatom

E. Synthesis of Six-Membered Rings with Two Heteroatoms

F. Synthesis of Six-Membered Rings with Three Heteroatoms

G. Synthesis of Miscellaneous Heterocyclic Rings

VI. Reactions of $\alpha$-Haloketones with Carboxylic Acids and Their Derivatives

VII. Reactions of $\alpha$-Haloketones with Carbon Nucleophiles

VIII. Reactions of $\alpha$-Haloketones with Alkenes and Alkynes

IX. Reactions of $\alpha$-Haloketones with Aldehydes and Ketones

X. Miscellaneous Reactions of $\alpha$-Haloketones

A. Cyanation and Thiocyanation

B. Sulfonation

C. Azidation

D. Carboxylation

E. Phosphorylation

F. Selenation

G. Oximation

H. Reductive Dehalogenation

I. Ketonic Reduction

K. Photochemistry of $\alpha$-Haloketones

L. Electrochemistry of $\alpha$-Haloketones

XI. Conclusion

XII. References

\section{Introduction}

$\alpha$-Haloketones, first obtained and described as early as the end of the eighteenth century [1], have been attracting increasing attention in view of their high reactivity as building blocks for the preparation of compounds of various classes due to their selective transformations with different reagents. Although over a century has been passed since the discovery of $\alpha$-haloketones, no comprehensive review articles on their synthetic potential in heterocyclic synthesis have been published. Much information describing the synthesis and the chemistry of $\alpha$-halogenated carbonyl 
compounds are scattered throughout the literature. There are short chapters dealing with the synthesis and reactivity of halogenated ketones in Patai's series [2] and in Houben-Weyl's series "Methoden der Organischen Chemie" [3,4]. In addition, the Favorskii rearrangement of $\alpha$-haloketones has been reviewed by several articles [5-9], and the reactivity of $\alpha$-haloketones towards nucleophiles was described by Tchoubar in 1955 [10]. It is our hope that by asembling a comprehensive survey of the widely scattered information on the chemistry of $\alpha$-haloketones as versatile synthons in heterocyclic synthesis, this will focus new attention on the broad potential of these compounds in the synthesis and mechanistic studies of heterocyclic compounds. This review will be restricted to halogenated ketones which carry one halogen atom on the carbon atom $\alpha$ - to a carbonyl function. The $\alpha$-halogenated aldehydes and carboxylic acids will not be treated in this article. Phenacyl halides are discussed in particular depth due to their frequent appearance in the literature.

\section{Molecular Structures and Spectral Properties}

A series of papers have investigated the rotation isomerism of $\alpha$-haloketones using Raman [11], IR [11-23] and NMR [24,25] spectroscopy. Although $\alpha$-haloketones can exist as two stereoisomers [11], it has been established, however, that the steric repulsion between the $\mathrm{Cl}$-atom and $\mathrm{O}$-atom, in the liquid state, is much less than that between $\mathrm{Cl}$-atom and an alkyl group. Both of the $\mathrm{Cl}$ and $\mathrm{O}$ atoms tend to adopt the cisoid-form $\left(\theta \simeq 0^{\circ}\right)$ which makes it more stable than the transoid-form (Figure 1).

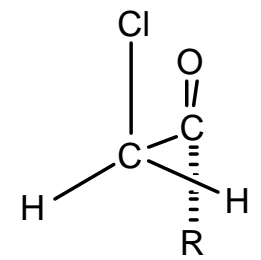

Figure 1. The cis-configuration of $\alpha$-haloketones $\left(\theta \simeq 0^{\circ}\right)$

An intensive conformational and electronic interaction studies of $\alpha$-substituted carbonyl compounds made by Olivato and co-workers [25]. These studies strongly indicate that $\alpha$ haloacetophenones display a cis (I)/gauche (II) rotational isomerism. The values of geminal $\mathrm{H}, \mathrm{H}$ coupling constants of some halomethyl ketones indicate and support that the halogen and oxygen atoms are eclipsed to each other (Figure 2) [24].

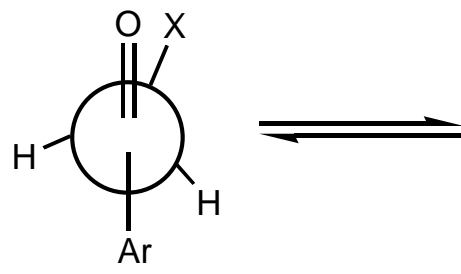

(I)

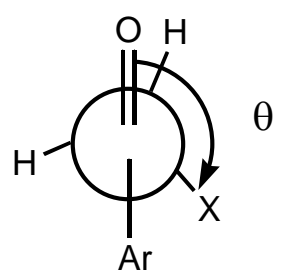

(II)

Figure 2. The cis/gauche rotational isomerism of $\alpha$-haloacetophenones 
Tables 1 and 2 show that the carbon in 4-substituted phenacyl bromides exhibits an upfield shift compared with the corresponding acetophenones. This is due to the inductive effect of the bromine atom [26-28].

Table 1. Physical and Spectral Data for Some 4-Substituted Phenacyl Bromides

\begin{tabular}{|c|c|c|c|c|c|}
\hline Substituent & M.p. $\left({ }^{\circ} \mathrm{C}\right)$ & $\operatorname{VCO}\left(\mathrm{cm}^{-1}\right)^{\mathrm{a}}$ & $\mathrm{CH}^{\mathrm{b}}$ & $\mathrm{H}-2, \mathbf{6}^{\mathrm{b}}$ & H- $3,5^{b}$ \\
\hline $\mathrm{H}$ & 51 & 1710 & 4.46 & 7.7 & 7.7 \\
\hline $\mathrm{Me}$ & $95-7$ & 1709 & 4.47 & 7.4 & 8.0 \\
\hline $\mathrm{Cl}$ & $108-9$ & 1710 & 4.40 & 7.6 & 7.8 \\
\hline $\mathrm{Br}$ & 52 & 1705 & 4.40 & 7.3 & 7.8 \\
\hline $\mathrm{OMe}$ & $74-5$ & 1700 & 4.40 & 6.9 & 7.8 \\
\hline $\mathrm{NO}_{2}$ & $97-8$ & 1716 & 4.50 & 8.2 & 8.3 \\
\hline
\end{tabular}

Table 2. ${ }^{13}$ C-NMR Chemical Shifts ${ }^{\mathrm{a}}$ of 4 -Substituted Phenacyl Bromides

\begin{tabular}{|l|c|c|c|c|c|c|}
\hline Substituent & $\mathbf{C H}_{\mathbf{2}}$ & $\mathbf{C}=\mathbf{O}$ & $\mathbf{C - 1}$ & $\mathbf{C - 2 , 6}$ & $\mathbf{C - 3 , 5}$ & $\mathbf{C - 4}$ \\
\hline $\mathrm{H}$ & 32.0 & 192.1 & 134.9 & 129.8 & 129.8 & 134.9 \\
$\mathrm{Me}$ & 32.1 & 190.6 & 131.2 & 128.8 & 129.4 & 145.5 \\
$\mathrm{Cl}$ & 31.6 & 189.9 & 132.0 & 130.1 & 129.4 & 140.2 \\
$\mathrm{Br}$ & 31.5 & 191.2 & 133.6 & 131.4 & 133.2 & 130.2 \\
$\mathrm{OMe}$ & 31.9 & 190.8 & 127.8 & 132.3 & 115.0 & 165.0 \\
$\mathrm{NO}_{2}$ & 31.4 & 190.8 & 139.4 & 131.0 & 125.0 & 151.6 \\
\hline
\end{tabular}

${ }^{\mathrm{a}}$ In $\delta(\mathrm{ppm})$ relative to $T M S$.

On the scale of carbonyl electrophilicities, measured by ${ }^{17} \mathrm{O}-\mathrm{NMR}$ spectroscopy [29], the presence of halogen atoms $\alpha$ - to the carbonyl group decreases the electron density around the oxygen atom (Table 3) [29,30].

Table 3. ${ }^{17} \mathrm{O}-\mathrm{NMR}$ Chemical Shifts of Phenacyl Compounds

\begin{tabular}{|l|c|}
\hline Compound & $\delta(\mathbf{C O})^{\mathbf{a}}$ \\
\hline $\mathrm{PhCOMe}$ & 549 \\
$\mathrm{PhCOCH}$ & $\mathrm{Cl}$ \\
$\mathrm{PhCOCH}_{2} \mathrm{Br}$ & 542.2 \\
$p-\mathrm{MeOC}_{6} \mathrm{H}_{4} \mathrm{COCH}_{2} \mathrm{Br}$ & 544.5 \\
$p-\mathrm{NO}_{2} \mathrm{C}_{6} \mathrm{H}_{4} \mathrm{COCH}_{2} \mathrm{Br}$ & 528.4 \\
\hline
\end{tabular}

${ }^{\mathrm{a}} \mathrm{In} \mathrm{MeCN}$ solution at $40^{\circ} \mathrm{C}$. 
The strength of the electric fields at the bromine atoms in the series of phenacyl bromides were also measured by ${ }^{79} \mathrm{Br}-\mathrm{NQR}$ spectroscopy which shows that the presence of carbonyl group decreases the electric fields at the bromine atom (Table 4) [31].

Table 4. ${ }^{79} \mathrm{Br}-\mathrm{NQR}$ Spectra of $\mathrm{BrCH}_{2} \mathrm{R}$ Derivatives

\begin{tabular}{|l|c|c|}
\hline Compound & $\gamma(\mathbf{M H z})$ & $\alpha(\mathbf{H z}$ cm $)$ \\
\hline $\mathrm{BrCH}_{2} \mathrm{COPh}$ & 276.09 & 535 \\
$\mathrm{BrCH}_{2} \mathrm{COAdBr} *$ & 275.06 & 495 \\
$\mathrm{BrCH}_{2} \mathrm{COC}_{6} \mathrm{H}_{4} \mathrm{Br}-p$ & 278.00 & 505 \\
$\mathrm{BrCH}_{2} \mathrm{Ph}$ & 259.13 & 660 \\
$\mathrm{BrCH}_{2} \mathrm{COOH}$ & 287.01 & 415 \\
\hline \multicolumn{2}{|c|}{ *Ad is 1-adamantyl }
\end{tabular}

The only crystal and molecular structures of acetophenones found in the literature are reported for anti- $\alpha$-bromoacetophenone oxime (Figure 3) [32,33].

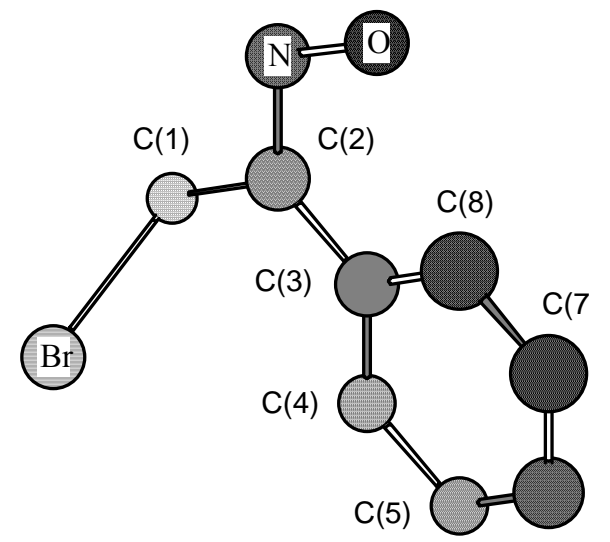

Figure 3. Structure of anti- $\alpha$-bromoacetophenone oxime

\section{Synthesis of $\alpha$-Haloketones}

A well-documented review by De Kimpe and Verhé [2] described in detail the synthesis of $\alpha$ halogenated ketones. We shall mention here references dealing with newer methods in addition to some common synthetic methods.

\section{A. General Methods}

In general, reaction of aliphatic ketones with halogen most commonly affords mono-substituted haloketones with some side products (Eq 1) [2,34].

$$
\mathrm{RCOCH}_{3}+\mathrm{X}_{2} \longrightarrow \mathrm{RCOCH}_{2} \mathrm{X}+\mathrm{HX}
$$


Direct fluorination, by using $\mathrm{F}_{2}$, often gives rise to side reactions leading to polyfluorinated and degradation products and are therefore of limited use. However, a number of reviews have been published by Erian [34] and others [35-37] on the preparation of $\alpha$-fluoroketones.

During the monochlorination of acetone, minor amounts of dichloroacetone are always isolated [38]. However, good results for the monochlorination of acetone and higher ketones are possible when the chlorination was carried out in aqueous solution of calcium carbonate [39-62].

The bromination of ketones with bromine is a reversible process. In order to shift the equilibrium towards the bromoketones, preparations have to be proceeded with removal of hydrogen bromide [6375].

\section{B. Miscellaneous Halogenating Agents}

The nucleophilic fluorination of alkyl iodides, bromides and of $\alpha$-bromo- or $\alpha$-chloroketones is smoothly affected by tetrabutylammonium hydrogen difluoride in the presence of a catalytic amount of pyridine, in dioxane, to give good yield of fluorinated compounds (Eq 2) [76].

$$
2 \mathrm{RX} \quad+\mathrm{HF}_{2}^{-} \stackrel{\mathrm{B}}{\longrightarrow} 2 \mathrm{RF}+2 \mathrm{X}^{-}+\mathrm{BH}^{+}
$$

The reaction of sterically less hindered $\alpha$-bromoalkyl and arylketones with tetrasulfur tetranitrideantimony pentachloride complex $\left(\mathrm{S}_{4} \mathrm{~N}_{4} \mathrm{SbCl}_{5}\right)$ in toluene at reflux gave the corresponding $\alpha$ chloroketones (Eq 3) [77].

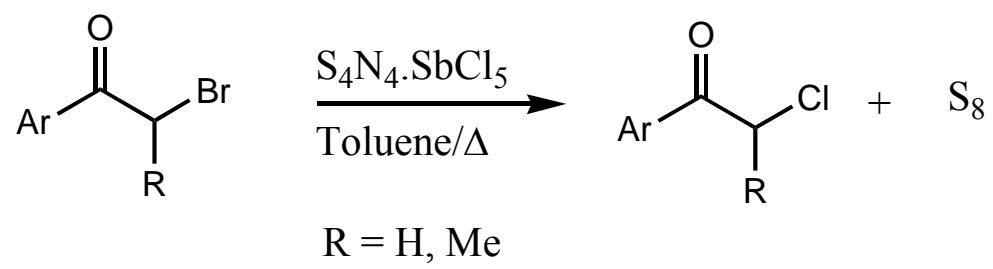

Reaction of 1,3-dicarbonyl compounds 1 with nitryl chloride resulted in the formation of the corresponding $\alpha$-chloro and $\alpha, \alpha$-dichloro derivatives $\mathbf{2}$ and $\mathbf{3}$ through substitution on the activated methylene group (Eq 4) [78].

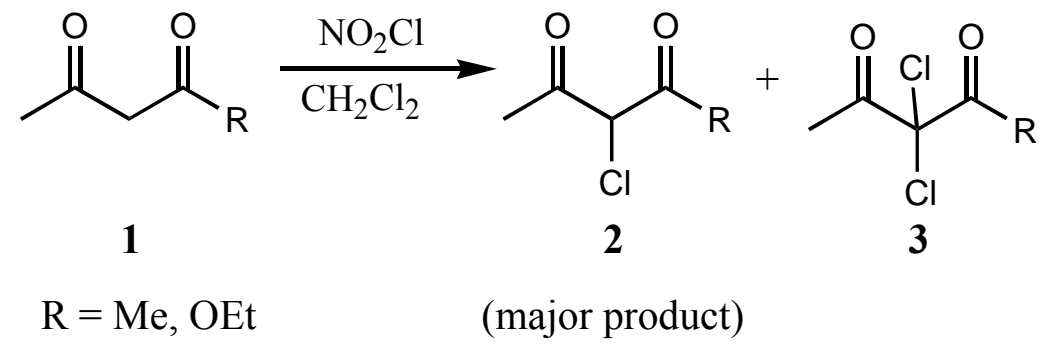

Fischer-type carbene complexes react via intermediate $\mathbf{5}$ and the bromoenolether $\mathbf{6}$ and via acid hydrolysis of the latter to afford bromomethyl ketones 7 (Scheme 1) [79]. 


\section{Scheme 1}
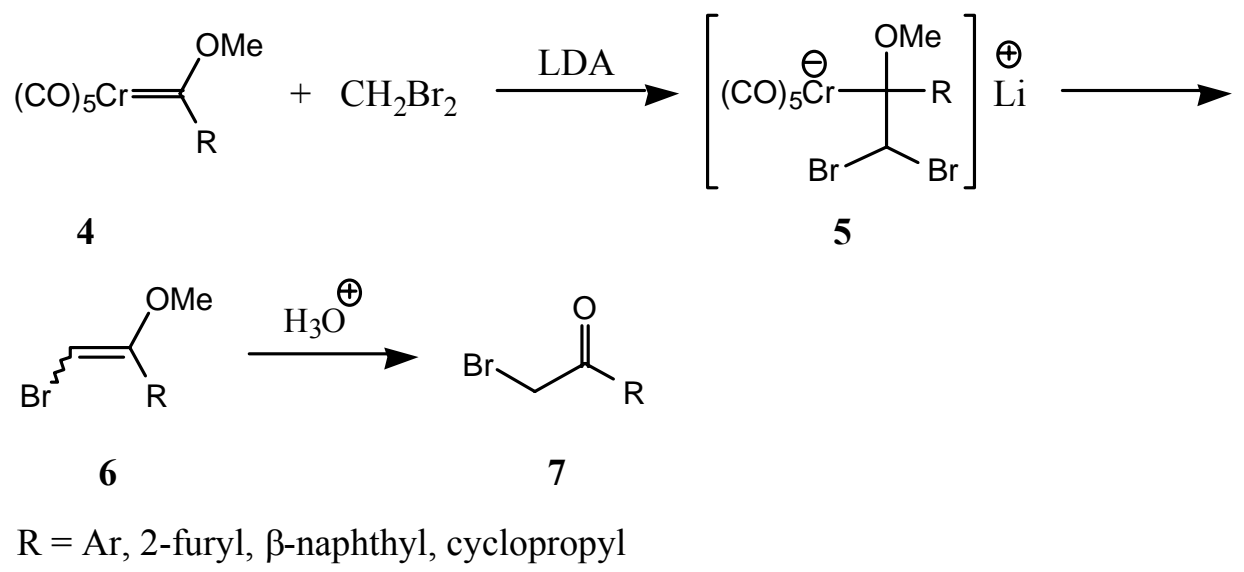

Tetrabutylammonium tribromide (TBATB) (9), an environmentally benign brominating agent, brominates a variety of organic substrates rather easily under mild conditions. It is also useful as a selective brominating agent for $\alpha, \beta$-unsaturated ketones, cf. the preparation of $\mathbf{1 1}$ from $\mathbf{1 0}$ (Scheme 2) [80].

\section{Scheme 2}

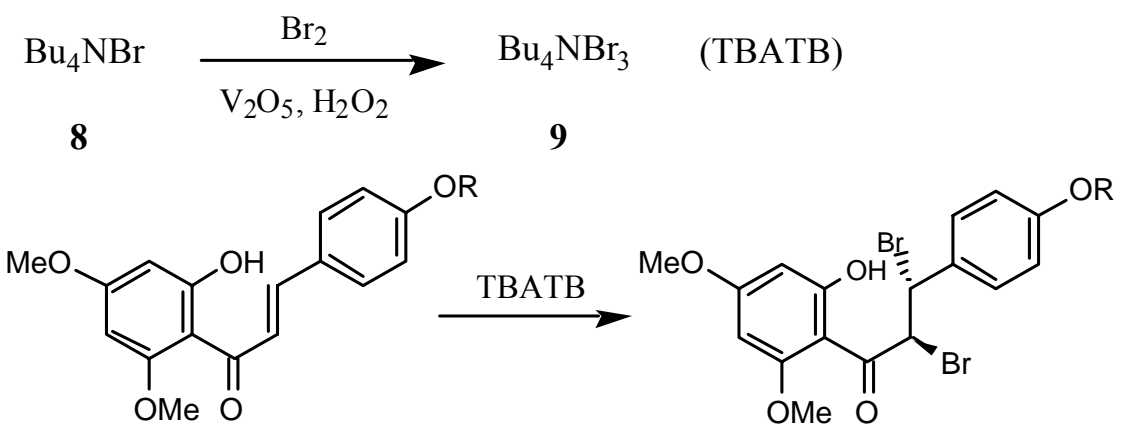

10

11

\section{Chemical Reactivity}

On treatment of an $\alpha$-haloketone with various nucleophiles, the attack can take place at six possible electrophilic sites [2]: the nucleophile is able to attack the carbon of the carbonyl function (position 1), the carbon atom carrying the halogen atom (position 2) and the halogen atom (position 3 ). In addition, due to the presence of two polar electron-withdrawing groups, the hydrogen atoms at the $\alpha$-, $\alpha^{\prime}$ - and $\beta$-positions also become susceptible to attack by nucleophiles or bases (positions 4,5 , and 6).

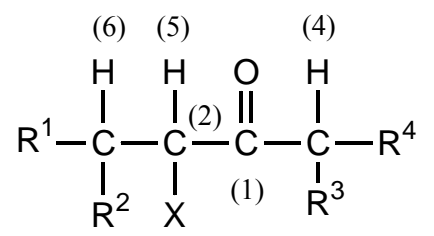


The interaction between the carbonyl group and the nucleophile is mainly electrostatic and the $\mathrm{SN}_{2}$ reactivity is due to polarization interaction caused by smaller steric requirement of RCO as compared to $\mathrm{RCH}_{2}$ (Eq 5) [81-89].

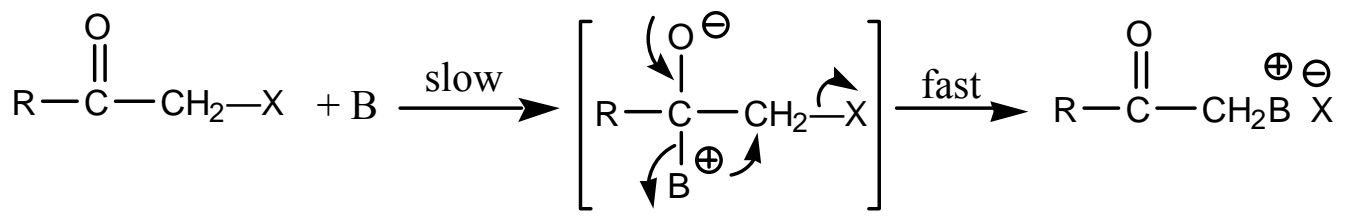

The isolation of stable epoxides in the reaction of an $\alpha$-haloketone with sodium methoxide and the evidence that these epoxides are reactive intermediates leading to other products gives rise to another explanation by Pearson [90] and others (Eq. 6) [6,91-94].

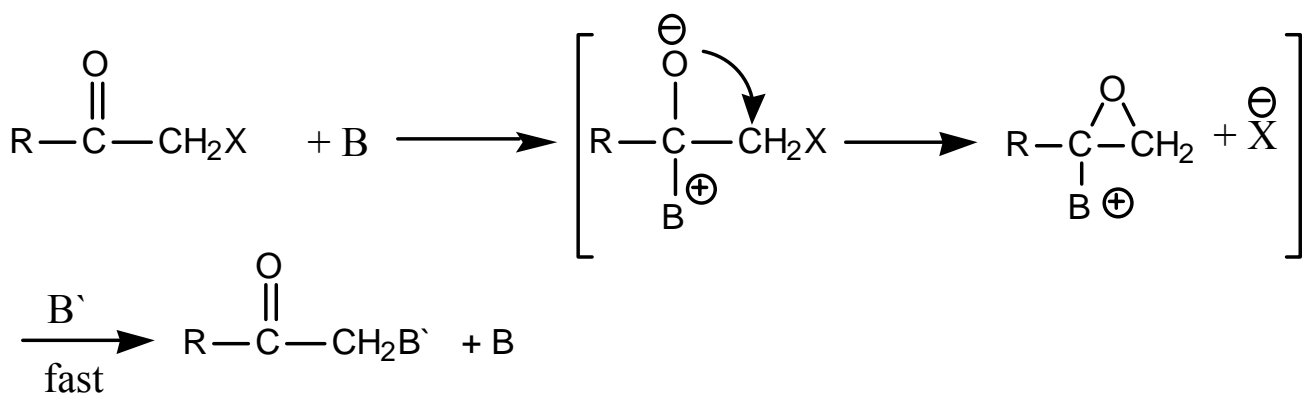

It is noteworthy that the reactivity of $\alpha$-haloketones is due to the inductive effect of the carbonyl group which enhances the polarity of the carbon-halogen bond by increasing the electron deficiency at the $\alpha$-carbon atom. Also, the more polar the $\mathrm{C}-\mathrm{X}$ bond, the faster the reaction with nucleophiles [95]. The data shown in Table 5 summarize the enhanced reactivity of $\alpha$-halogenated ketones relative to the corresponding alkyl halides in bimolecular nucleophilic substitution reactions [96-99].

Table 5. Reactivity Relative to that of $\mathrm{C}_{3} \mathrm{H}_{7} \mathrm{X}$ of $\alpha$-Halocarbonyl Compounds in Nucleophilic Substitutions

\begin{tabular}{|l|c|c|c|c|l|}
\hline Reaction & $\boldsymbol{n}-\mathbf{C}_{\mathbf{3}} \mathbf{H}_{7} \mathbf{X}$ & $\mathbf{P h C H}_{2} \mathbf{X}$ & $\mathbf{C H}_{3} \mathbf{C O C H}_{2} \mathbf{X}$ & PhCOCH $_{2} \mathbf{X}$ & ref. \\
\hline $\mathrm{R}-\mathrm{Cl}+\mathrm{KI} /$ acetone & 1 & 197 & 35700 & 105000 & 96 \\
$\mathrm{R}-\mathrm{Cl}+\mathrm{S}_{2} \mathrm{O}_{3}{ }^{-} / \mathrm{H}_{2} \mathrm{O}$ & 1 & - & 1400 & 1600 & 98 \\
$\mathrm{R}-\mathrm{Cl}+{ }^{-} \mathrm{OAc} / \mathrm{MeOH}$ & 1 & - & 198 & 228 & 98 \\
$\mathrm{R}-\mathrm{Br}+$ pyridine$/ \mathrm{MeOH}$ & 1 & 286 & 208 & 406 & 96 \\
$\mathrm{R}-\mathrm{Br}+$ thiourea/MeOH & 1 & 300 & - & 10700 & 97 \\
$\mathrm{R}-\mathrm{Cl}+{ }^{-} \mathrm{SCN} / \mathrm{MeOH}$ & 1 & - & 401 & 770 & 98 \\
\hline
\end{tabular}




\section{Reactions of $\alpha$-Haloketones with Oxygen, Nitrogen and Sulfur Nucleophiles}

The reactions of $\alpha$-haloketones with oxygen, nitrogen and sulfur nucleophiles are classified separately in one category due to the huge number of references. We have arranged this huge volume of data in terms of the type of the heterocycles formed, starting with five and six membered rings in order of increasing number of heteroatoms. Such systematic treatment provides a clear idea about the synthetic possibilities of the method and may be useful in selecting the direction of further research.

\section{A. Synthesis of Five-Membered Rings with One Heteroatom}

\section{Furans and Their Fused Derivatives}

The condensation of $o$-hydroxyacetophenone derivatives $\mathbf{1 2}$ with phenacyl bromides under PTC (phase transfer catalysis) conditions in a two phase system, using aqueous $\mathrm{K}_{2} \mathrm{CO}_{3}(20 \%)$ as a base, dichloromethane or benzene as solvent and tetrabutylammonium hydrogen sulfate as the phase transfer catalyst, furnished 2-aroylbenzofurans $\mathbf{1 5}$ in a good yield and high purity as well (Scheme 3) [100-102].

\section{Scheme 3}

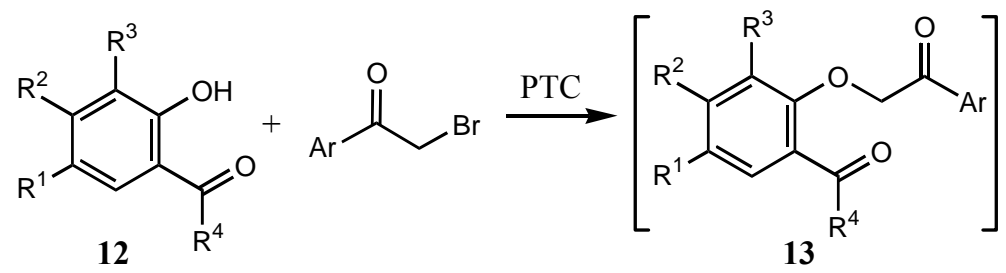

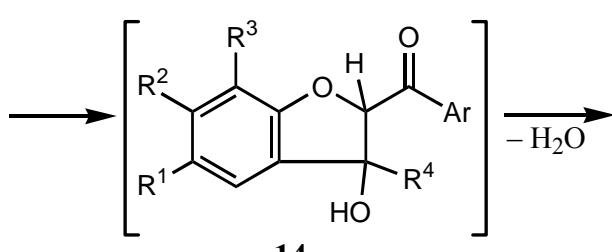

14<smiles>[R]c1cc2c([Z7])c(C(=O)Br)oc2c([R])c1[R]</smiles>

15

The reaction of $\alpha$-haloketones with $o$-hydroxycarbonyl compounds gave a variety of substituted benzofurans. Benzofuran compounds 16 and 18 were produced via cyclocondensation of $\alpha$-haloketones with $o$-hydroxybenzophenone and salicylaldehyde, respectively (Scheme 4) [103-105].

\section{Scheme 4}

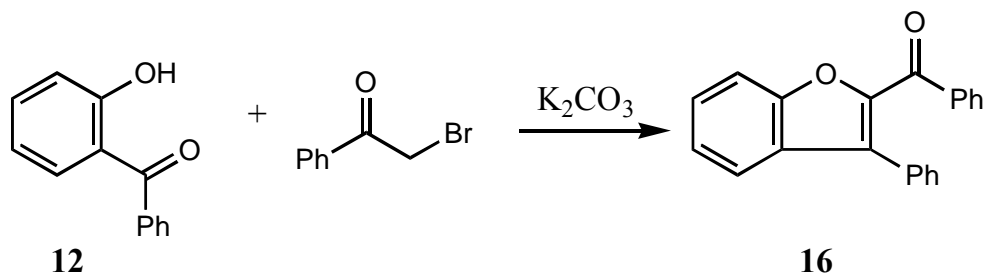




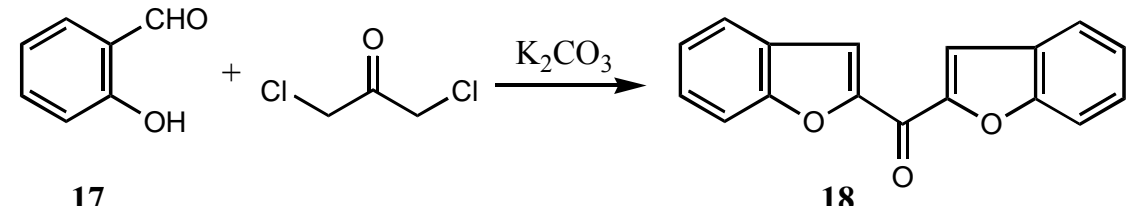

Difurano[2,3-a:2',3'-f]naphthalenes 21 are easily synthesized in two steps starting with 1,5dihydroxynaphthalene (19) (Scheme 5) [106].

\section{Scheme 5}

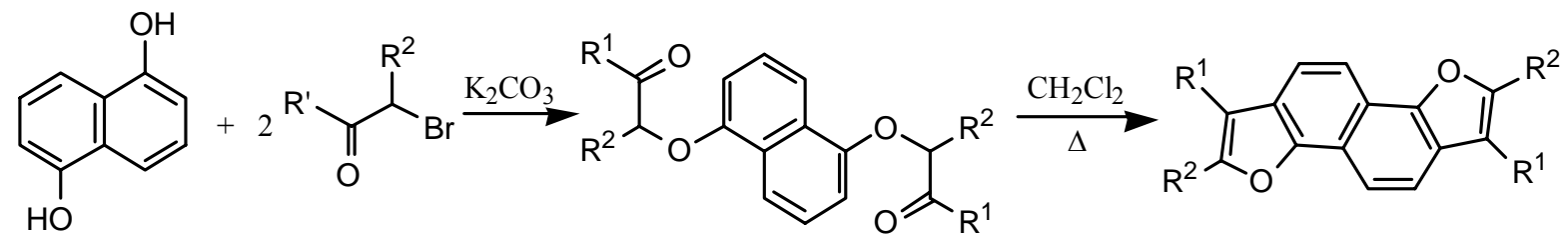

19

20

21

It is claimed that heating peri-(acyloxy)naphthyl- $\alpha$-bromomethyl ketones 22 in pyridine gave naphthofuranone 23 (Scheme 6) [107].

\section{Scheme 6}<smiles>[R]Oc1cccc2c(OC)ccc(C(=O)CBr)c12</smiles>

22<smiles>COc1ccc2c3c(cccc13)OC2=O</smiles>

23

3-Aryl-5,6-methylenedioxy-2-nitrobenzofurans 26, effective bactericides against Staphylococcus aureus at $100 \mathrm{mg} / \mathrm{kg}$ in mice, were prepared by cyclization of acetophenone derivatives 24 with poly phosphoric acid followed by bromination and nitration [108,109]. Similarly, 4-hydroxycoumarin (27) condensed with $\alpha$-chloroketones to give furocoumarins 28 (Scheme 7) [110]. 


\section{Scheme 7}

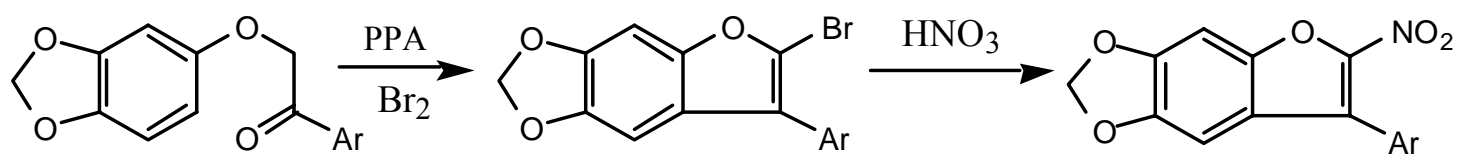

24<smiles>O=c1cc(O)c2ccccc2o1</smiles>

27
25

26

-Hydroxybenzonitriles 29 reacted with $\alpha$-haloketones to give 3-aminobenzofuran derivatives $\mathbf{3 1}$ (Scheme 8) [111,112].

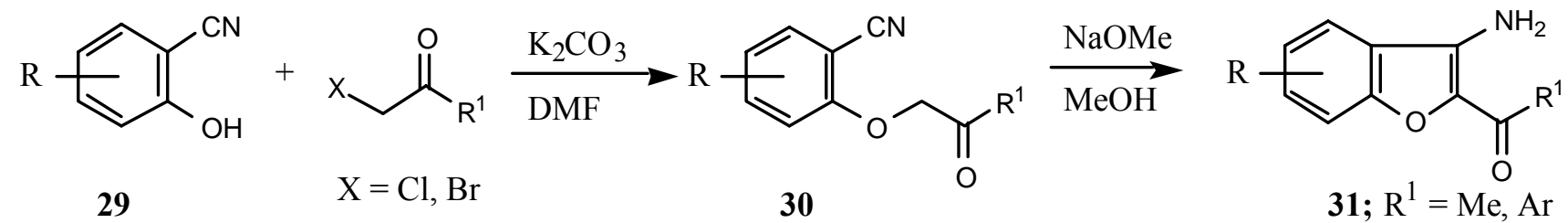

3-Aminofuro[2,3- $b$ ]pyridine derivatives 33 could be synthesized via the condensation of pyridones 32 with phenacyl bromide (Scheme 9) [113].<smiles>[R]c1c(Nc2ccccc2)[nH]c(=O)c(C#N)c1[R]O[N+](=O)[O-]</smiles>

32, $\mathrm{R}^{1}, \mathrm{R}^{2}=$ alkyl groups

\section{Scheme 8}

\section{Scheme 9}

\section{8}




\section{Scheme 10}<smiles>[R]/C(N)=C(/[Y])[W]</smiles>

34 $+x \bigwedge_{\mathrm{O}}^{\mathrm{R}} \frac{\mathrm{K}_{2} \mathrm{CO}_{3}}{\mathrm{DMF}}$

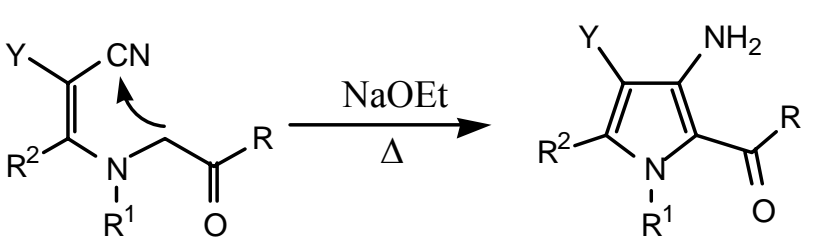

35

36, $\mathrm{Y}=\mathrm{CO}_{2} \mathrm{Et}, \mathrm{CN}, \mathrm{CONH}_{2}$

The Hantzsch pyrrole synthesis using enamine 37, derived from dimethyl acetone dicarboxylate and ethanolamine, was used similarly for the preparation of the pyrrole diesters 38 . The latter were converted into compounds 39 (Scheme 11) [121].

Scheme 11<smiles></smiles>

The pyrrolidine derivative $\mathbf{4 2}$ could be prepared via alkylation of the dialkylamine 40 with phenacyl bromide to give 41, which cyclized upon treatment with sodium methoxide (Scheme 12) $[122,123]$.

\section{Scheme 12}

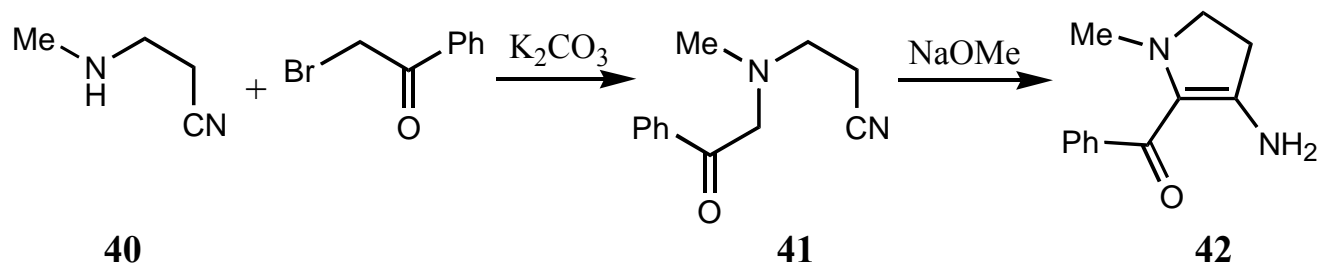

The acid hydrolysis of 3,5-dibromopiperidin-4-one derivative 43 gives the pyrrolidine 46 via the intermediate 45 (Scheme 13) [124,125]. 


\section{Scheme 13}

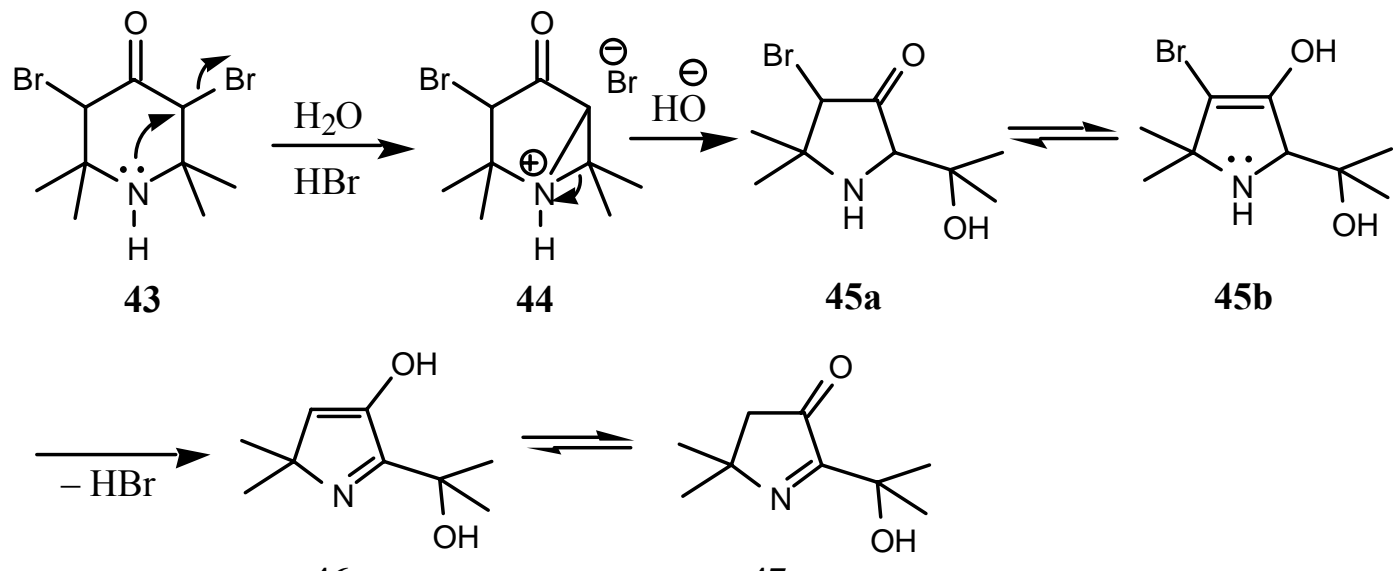

46

47

The reaction of aromatic amines 48 with $\alpha$-bromoketones is an attractive synthetic route to indoles 50 (Scheme 14) [126-132].

Scheme 14

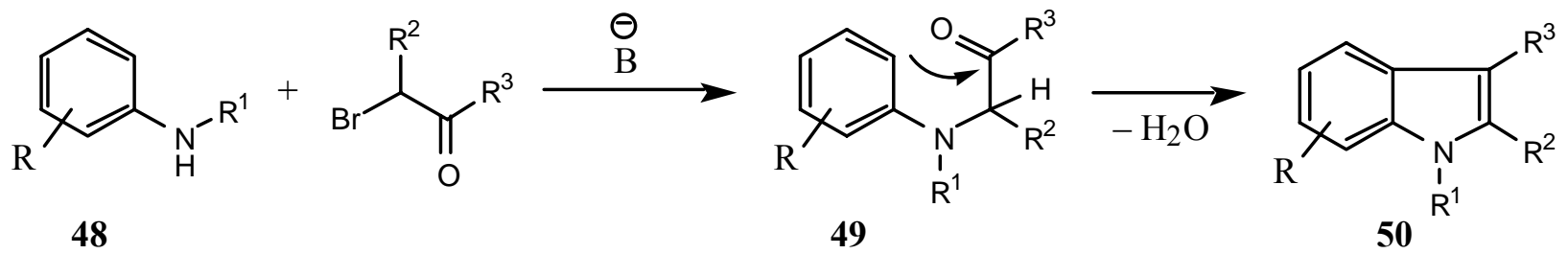

Carbazole derivatives 54 could be obtained via the reaction of primary aromatic amines 51 or 55 with $\alpha$-chlorocyclohexanone (52) (Scheme 15) [133-135].

Scheme 15<smiles>[R]c1cccc(C2(O)CCCCC2Cl)c1N</smiles>

51

52

53<smiles>[R]c1cccc(N)c1</smiles>

55

52

54 
When $N$-carbethoxyanthranilonitrile (56) was treated with sodium hydride and phenacyl bromide in DMF, the corresponding 3-amino-2-benzoylindole derivative $\mathbf{5 8}$ was obtained in good yield (Scheme 16) [136,137].

\section{Scheme 16}<smiles>N#Cc1ccccc1NC(=O)OCCN</smiles>

56

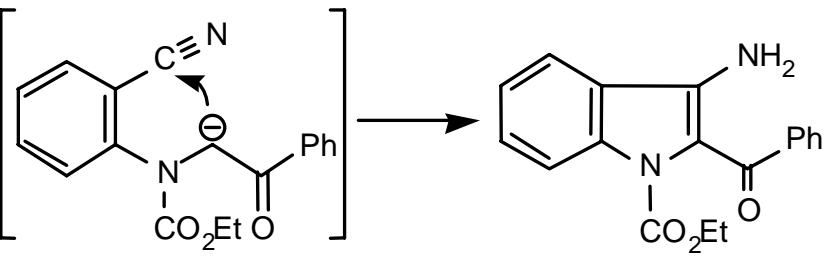

57

58

The pyrrolidino[2,3-c]pyrazol-3-ones 61 were prepared by Cocco et al. [138,139] via reaction of $N^{\prime}$ - acyl-2-ethoxycarbonylacetamidrazones 59 with $\alpha$-bromoketones (Scheme 17).

\section{Scheme 17}<smiles>CCOC(=O)CC(N)=NC=O</smiles>

59<smiles>CCOC(=O)N1N=C(N)CC1=O</smiles>

60<smiles>[R]C1(O)CNC2=NN(C(=O)O)C(=O)C21</smiles>

61

Few reports have dealt with the reactivity of $\alpha$-haloketones with imines to give pyrroles. The synthesis of 4-azahomoadamantano[4,5]pyrroles $\mathbf{6 5}$ was attained via substitution and imine cyclization by reaction of imines 62 with $\alpha$-haloketones (Scheme 18) [140].

\section{Scheme 18}<smiles>PCC1=NC2CC3CC(C2)CC1C3</smiles>

62<smiles>[R7]CC(=NC([R])C(=O)P)C1CC2CC3CC1CC(C3)C2[R]</smiles>

63

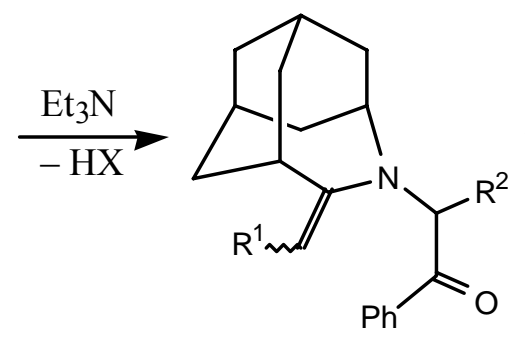

64

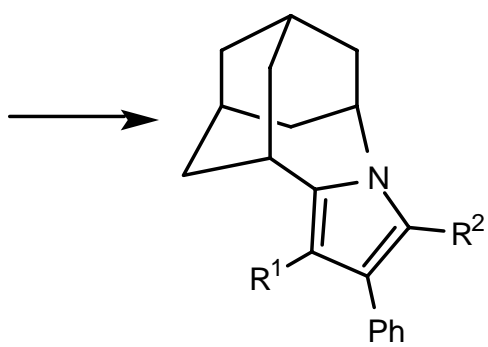

65 
The reaction of $\alpha$-haloketones with $N$-heterocyclic compounds shown in Scheme 19 is completely different and leads to quarternization in most cases [141,142]. This reaction has been used in the Chichibabin quaternization followed by cycloaddition of the obtained ylides with alkenes or alkynes to give the corresponding fused pyrrole derivatives starting from pyridines [143-151], pyridazines [152], pyrimidines [153,154], pyrazines [155-157], imidazoles [158-161], thiazoles [162,163], and triazoles [164-168]. This general synthetic route to pyrroles a-fused to a heterocyclic ring may be represented by the preparation of $\mathbf{6 8}$ starting from $\mathbf{6 6}$ (Scheme 19).

\section{Scheme 19}<smiles>[X]CC(=O)[R]c1ccncc1</smiles>

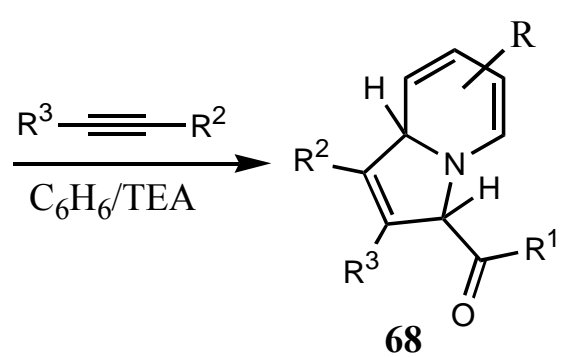

$67 b$

Indolizine derivatives 70 were synthesized by Anitha and Rajan [196] using two methods: by quaternization of $\alpha$-picolone (66) with acylmethylene bromide then cyclization or by King's method (Scheme 20).

Scheme 20

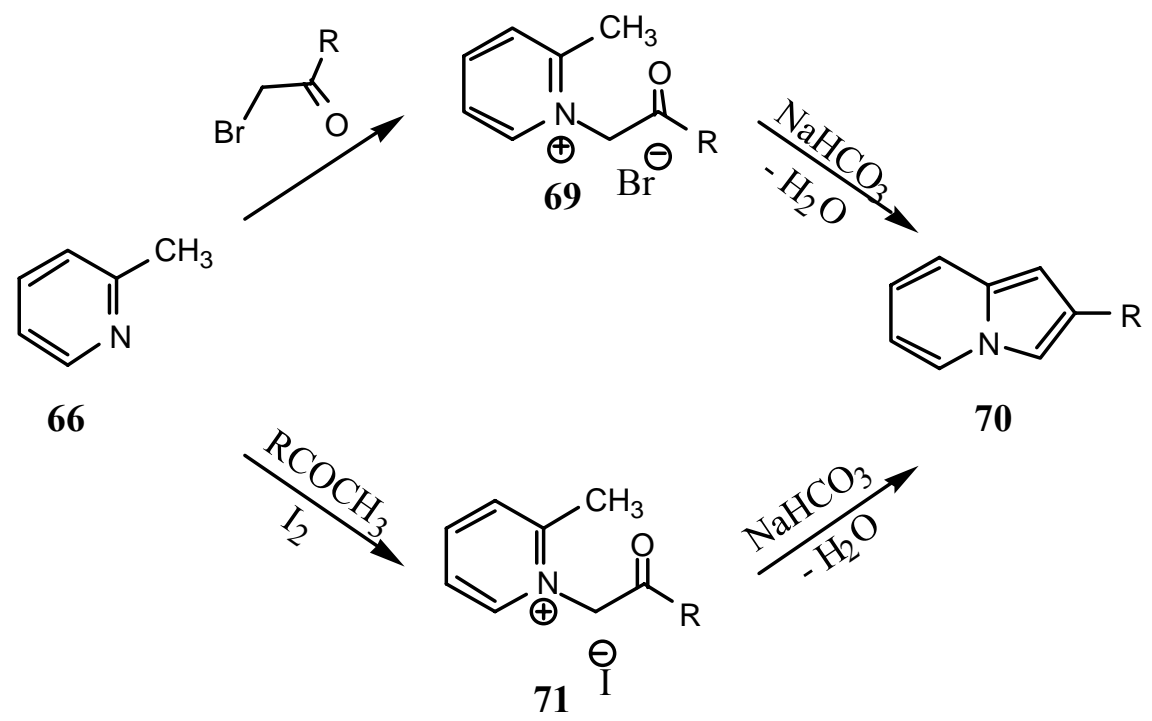


The reaction of 2,3-cycloalkenopyridines 72 with bromoacetone or phenacyl bromide in dry acetone gave the corresponding pyridinium salts 73 , which could be cyclized into indolizine derivatives 74 upon boiling in ethanol containing potassium carbonate [170]. Similarly, 2-substituted3,4-dihydro-pyranoindolizines 75 was obtained (Scheme 21) [171].

Scheme 21

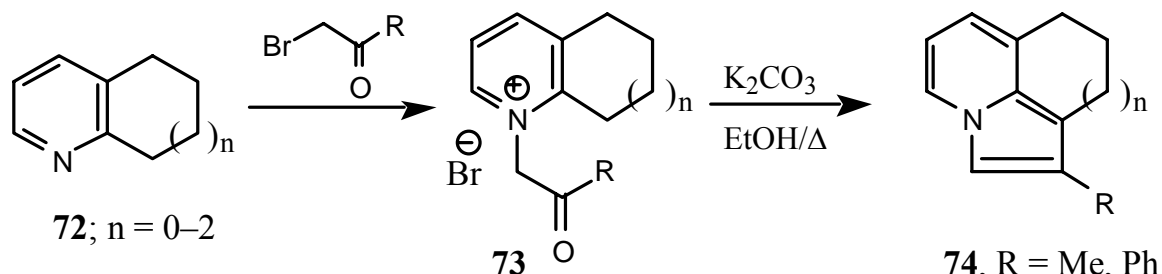<smiles>[R]c1cn2ccccc2c1CCO</smiles>

75

Synthesis of the azaphenanthrene alkaloid eupoulauramine $\mathbf{8 3}$ has been achieved starting from 3bromopyridine (76) (Scheme 22) [172].

\section{Scheme 22}
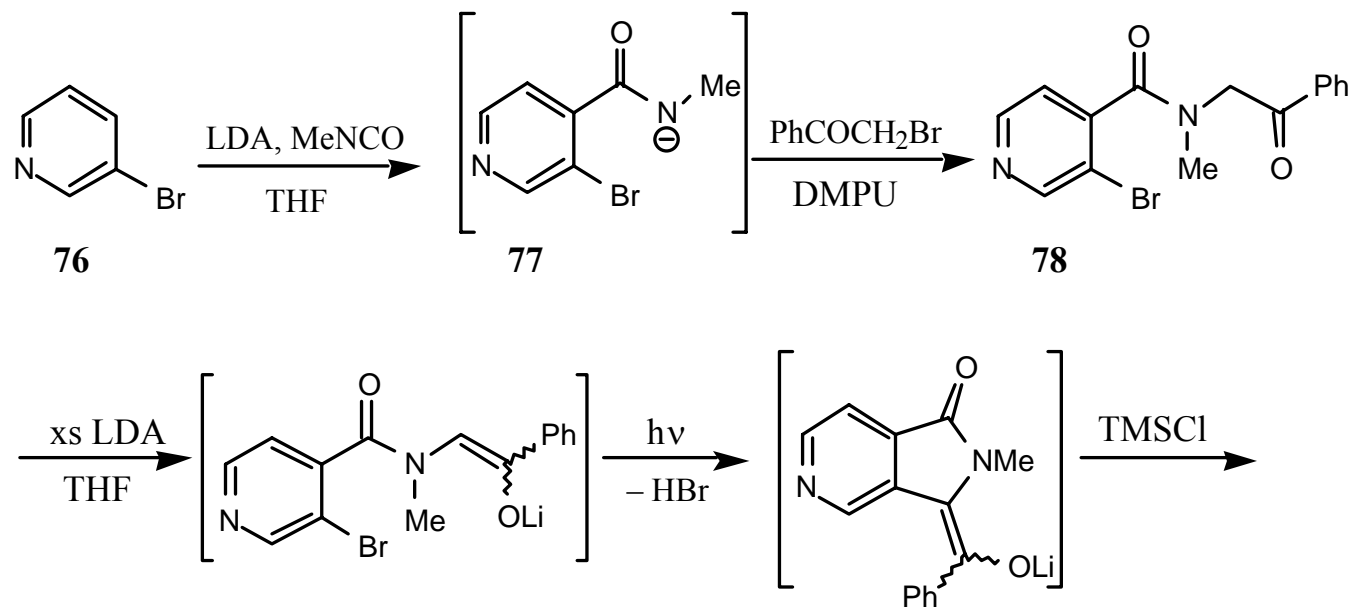<smiles>COC(=O)C1NC(=O)c2ccncc21</smiles>

81

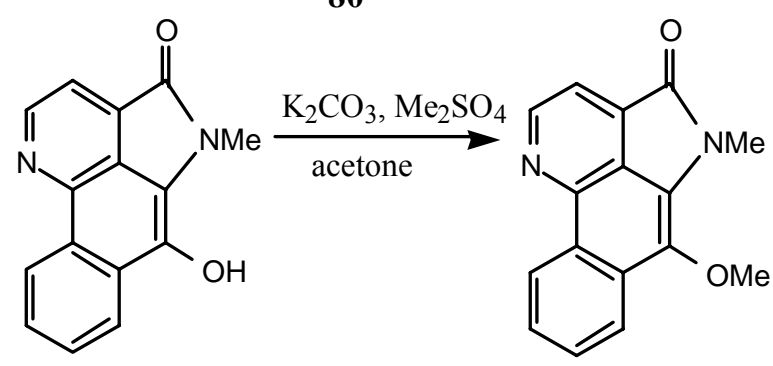

82
83

DMPU = dimethylpropyleneurea

$\mathrm{TMSCl}=$ trimethylsilyl chloride 


\section{Thiophenes and Their Fused Derivatives}

The reaction of carbon disulfide with active methylenes have been studied with many groups [173181], especially with a view of thiophene synthesis. Scheme 23 summarizes the use of carbon disulfide in thiophene synthesis.

Scheme 23

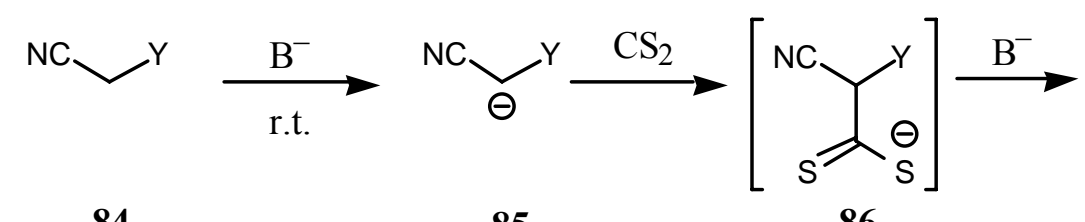

84

85

86

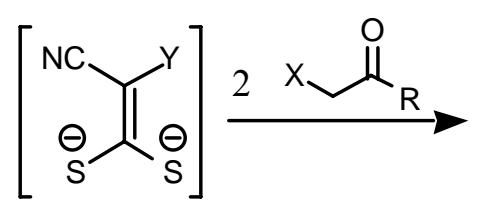

87

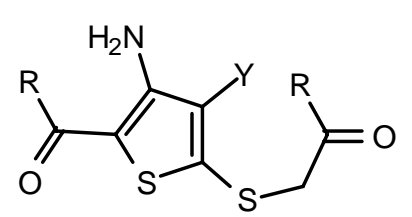

88

Reaction of $\alpha$-haloketones with inorganic sulfide salts give diketosulfides $\mathbf{8 9}$ in $50-80 \%$ yields (Scheme 24). The latter could be reacted with glyoxal to give thiophene derivatives 90 [182-187].

Scheme 24

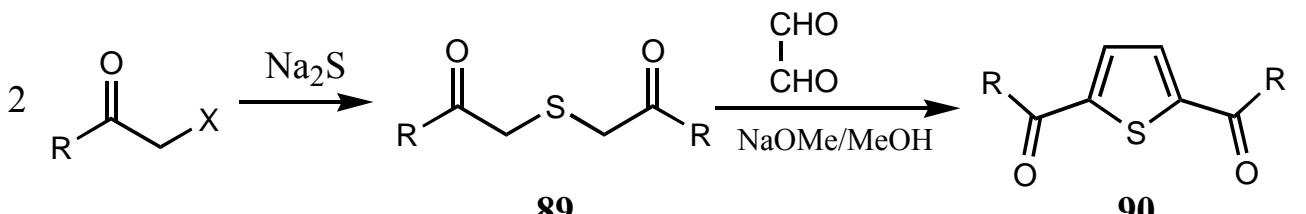

89

90

$\beta$-Chloro- $\alpha$-cyanocinnamonitrile (91) reacted in one step with $\mathrm{Na}_{2} \mathrm{~S}$ and $\alpha$-chlorocarbonyl compounds to form 3-aminothiophenes 93 (Scheme 25) [188].

Scheme 25<smiles>[R]C(=O)c1sc(-c2ccccc2)c(C(=O)CCl)c1N</smiles>

91

92

93

One of the most successful methods for the synthesis of 3-aminothiophenes 95 is the addition of an aryl isothiocyanate to active methylenenitrile compounds 84 in an alkaline medium, followed by heterocyclization of intermediate 94 with $\alpha$-haloketones (Scheme 26) [174,189-198]. 


\section{Scheme 26}

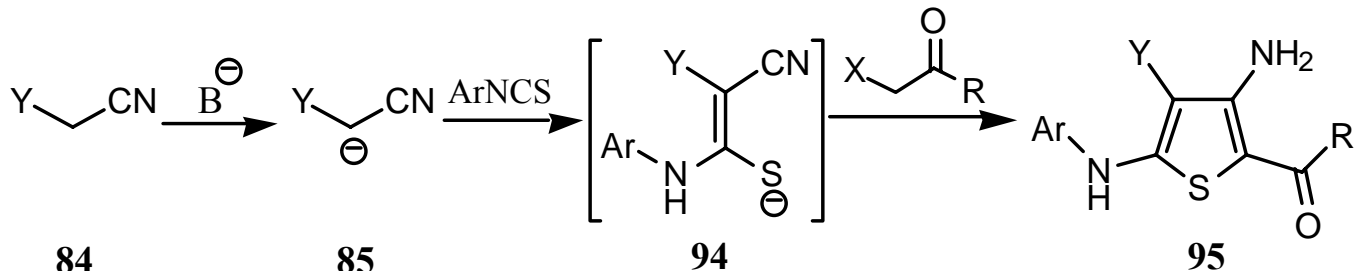

84

85

94

95

$o$-Mercaptonitriles 96 reacted with $\alpha$-haloketones to give 3-aminothiophenes 98 (Scheme 27) [199201].

\section{Scheme 27}

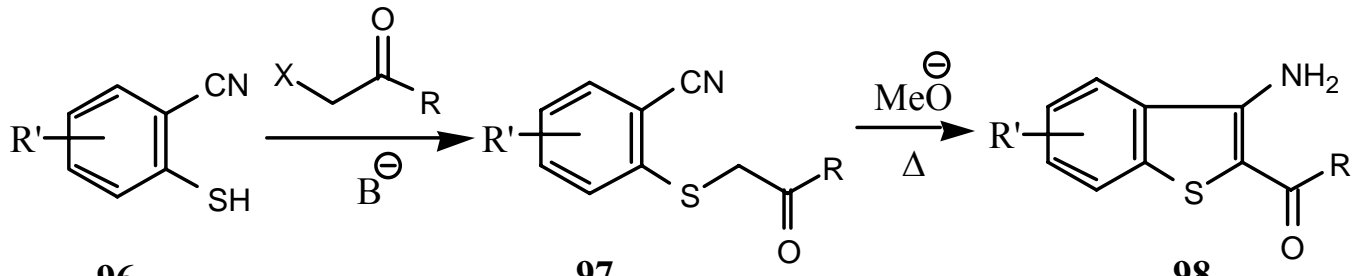

96

97

98

Some of the most interesting derivatives of thiophenes are 3-aminothieno[2,3-b]pyridines, in view of their wide spectrum of high biological activities and valuable properties in many applications [202204]. It is noteworthy that investigators [205-229] have devoted considerable attention in recent years to the synthesis of thieno[2,3-b]pyridines 101 via $S$-alkylation of 3-cyanopyridine-2(1H)-thiones 99 with $\alpha$-haloketones (Scheme 28).

\section{Scheme 28}<smiles>[X]CC(=O)CC(C)C(=O)O[Na]</smiles>

99<smiles>[R]C(=O)CSc1nc([R])c([2H])c([R])c1C#N</smiles>

100<smiles>[R]C(=O)c1sc2nc([R])c([R])c([R])c2c1N</smiles>

101

Anodic monofluorination of 2-pyridinyl sulfides 102 yields the corresponding $\alpha$-fluoromethylpyrindinyl sulfides $\mathbf{1 0 3}$. The latter were cyclized readily in a basic medium to give the thienopyridine3-imines 104. Compounds 104 form, in the presence of ethanol, the intermediates 105 which, in turn, are aromatized to give 3-amino-2-fluorothieno[2,3-b]pyridines 106 (Scheme 29) [230-234]. 


\section{Scheme 29}

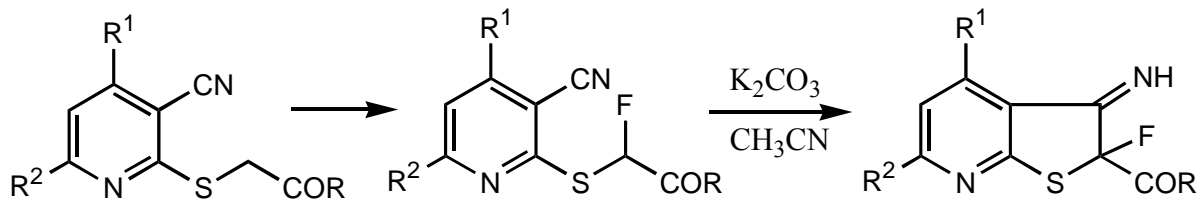

102

103

104<smiles>[R7]c1cc([R])c2c(N)c(F)sc2n1</smiles>

The reaction of 5-mercaptoisothiazole-4-carbonitriles 107 with $\alpha$-haloketones in an alkaline medium gave thieno[2,3-c] isothiazole derivatives 109 (Scheme 30) [235,236].

\section{Scheme 30}

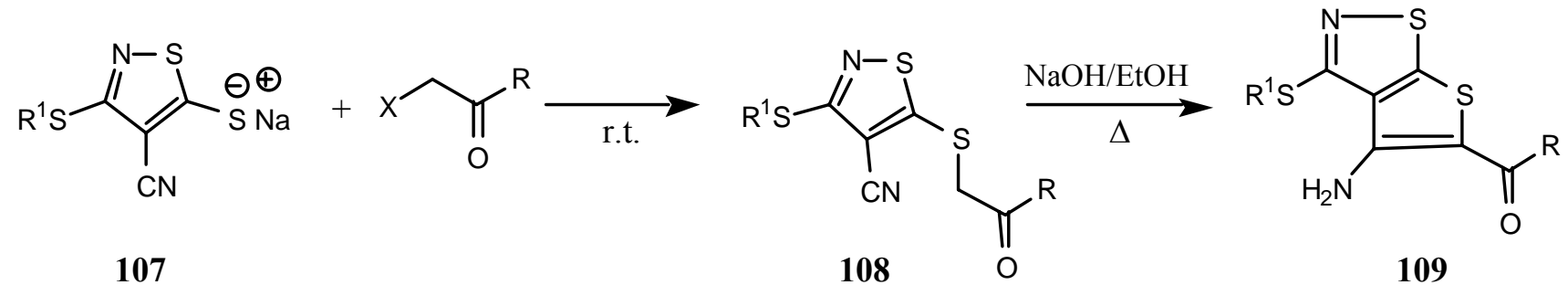

Reaction of 1,8-diketones 111 with Lawesson's reagent resulted in the formation of the corresponding thienodithiolane derivatives 113 in good yields (Scheme 31) [237].

\section{Scheme 31}<smiles>[NH3+][SeH]c1sc(=S)sc1[18OH]</smiles>

110<smiles>[R]C(=O)CSc1sc(=S)sc1SCC([R])=O</smiles>

111

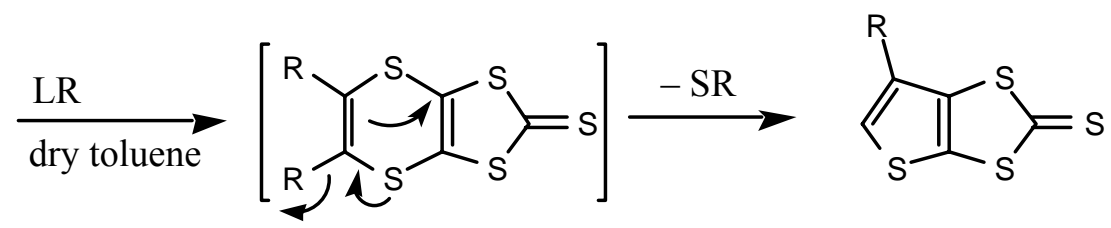

112 
Addition of the pyrrolidine enaminothiones 114, with a semicyclic $\mathrm{C}=\mathrm{C}$ bond, to $\alpha$-bromocarbonyl compounds leads to the corresponding 4,5-dihydro-6H-thieno[2,3-c]azepines 118 (Scheme 32) [238].

\section{Scheme 32}<smiles>[R7]C(=S)C([PH2+])=C1CC([R])([R])CN1</smiles>

114<smiles>[R]C(=O)CS/C([R])=C(\[R])CSCC</smiles>

115

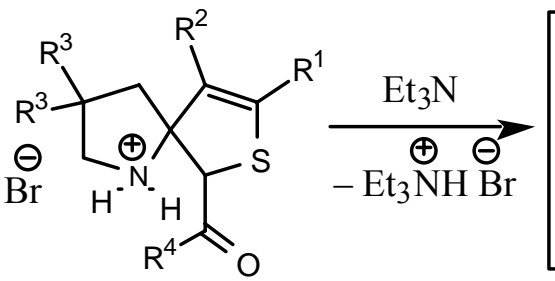

116<smiles>[R]C(=O)c1sc(C)c(CC(C)C)c1CC([R])([R])CN</smiles>

117<smiles>[R]C1=NCC([R])([R])Cc2c1sc([R])c2[R]</smiles>

118

\section{B. Synthesis of Five-Membered Rings with Two Heteroatoms}

\section{Imidazoles and Their Fused Derivatives}

Several attempts were made for the synthesis of 2 -aminoimidazole derivatives by reacting $\alpha$ bromoketones with guanidines [239-249]. Little and Webber [239] have observed a clean reaction when $\alpha$-haloketones were stirred, at room temperature in anhydrous DMF, with excess of $N$-acetylguanidine (119) to yield the corresponding 4,5-disubstituted $N$-( $1 H$-imidazol-2-yl)acetamides $\mathbf{1 2 0}$, which are then hydrolyzed into 121. On the other hand, the reaction of $\alpha$-bromoketones with urea derivatives 122 gives the corresponding imidazolone derivatives 123 (Scheme 33) [250-253].

\section{Scheme 33}

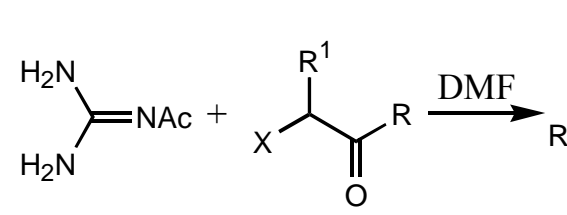

119<smiles>[R]c1nc(NC(O)C(=O)O)[nH]c1[TlH]</smiles>

120<smiles>[R]c1nc(N)[nH]c1[R]</smiles>

121

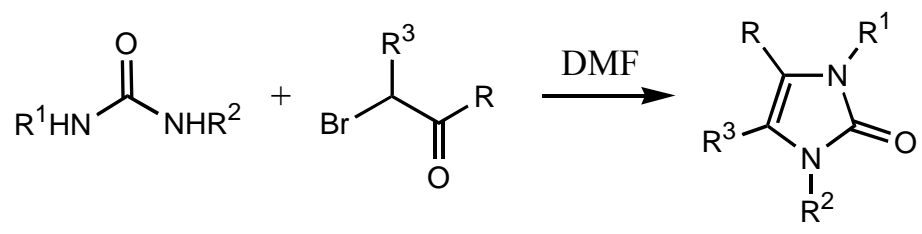


Various ring systems containing the $-\mathrm{C}\left(\mathrm{NH}_{2}\right)=\mathrm{N}-$ moiety as a part of the ring have been found to condense with $\alpha$-bromoketones to yield condensed imidazo-heterocyclic systems; the ring nitrogen attacks the $\mathrm{CH}_{2} \mathrm{Br}$ unit rather than the primary exocyclic amino group and imidazo[1,2- $\left.b\right]$ pyrazoles [254,255], imidazo[1,2-a]benzimidazoles [256-259], imidazo[2,1-b]oxazoles [260], imidazo-[2,1- $b$ ] thiazoles [261-267], imidazo[2,1-b]-1,3,4-thiadiazoles [268-272], imidazo[1,2- $d$ ] tetrazoles [273, 274], are the well-known condensed imidazo-heterocyclic systems thus prepared. A general systematic preparative route for such fused imidazoles 126 can be presented starting from 124 (Scheme 34).

\section{Scheme 34}

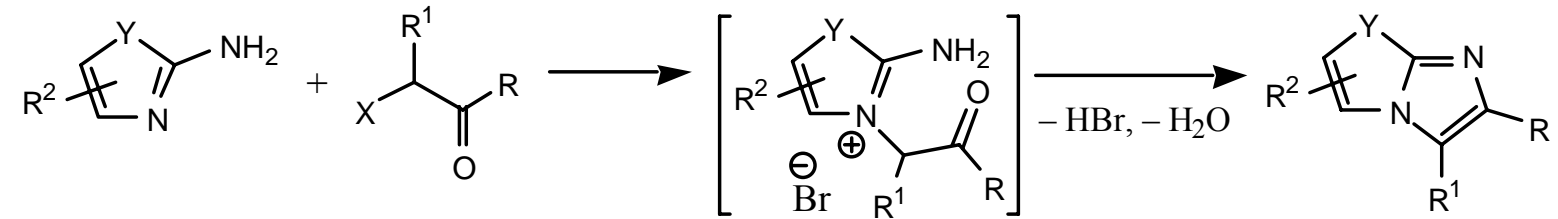

124

125

126

Similarly, imidazo[1,2-a]pyridines [275-282], imidazo[1,2-c]pyrimidines [283-288] and imidazo$[2,1-c][1,4]$ benzoxazines [289] were obtained starting with 2-aminoazines 127 (Scheme 35).

Scheme 35

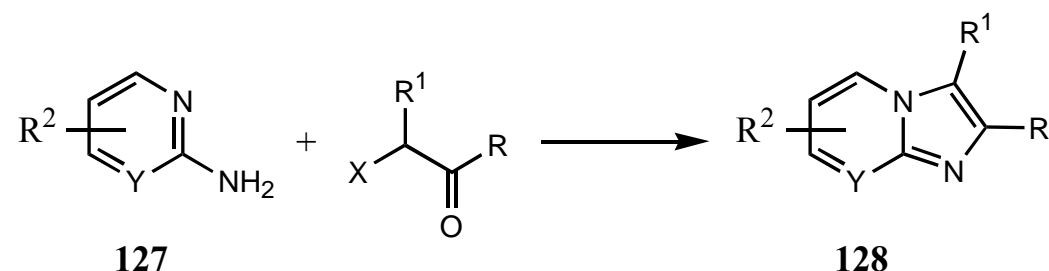

\section{Thiazoles and Their Fused Derivatives}

The Hantzsch thiazole synthesis using the condensation of $\alpha$-haloketones with thioureas [290-305] or thioamides [306-321] 129 was established a century ago [290,291]. It is well-known that during Hantzsch thiazole synthesis an intermediate 130a and/or a cyclic hydroxy isomer 130b is formed (Scheme 36).

\section{Scheme 36}

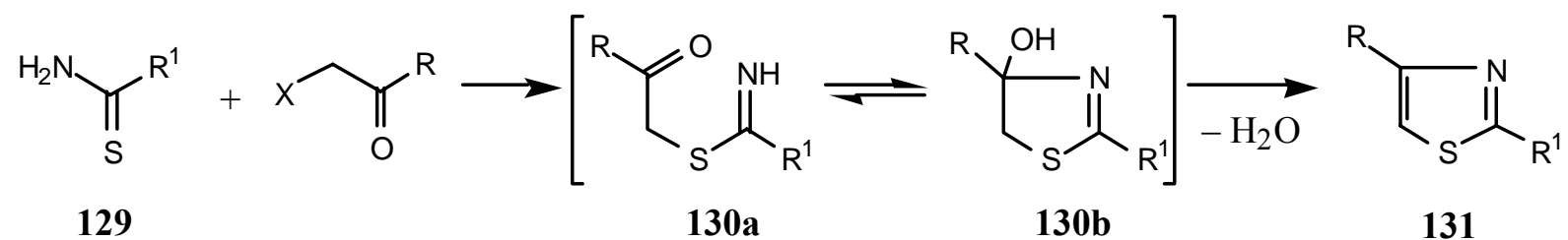

Thiazole-2-thiones 135 could be synthesized according to the method of Sandstrom [322,323]. The reaction of primary alkyl, aryl or heterocyclic amines 132 with carbon disulfide in dry DMF, 
containing potassium hydroxide, afford the potassium thiocarbamate intermediate salt $\mathbf{1 3 3}$. The latter reacted, in situ, with $\alpha$-haloketones to give the corresponding thiazole-2-thione derivatives 135 via the $S$-alkyl intermediate 134 (Scheme 37) [324-329].

\section{Scheme 37}

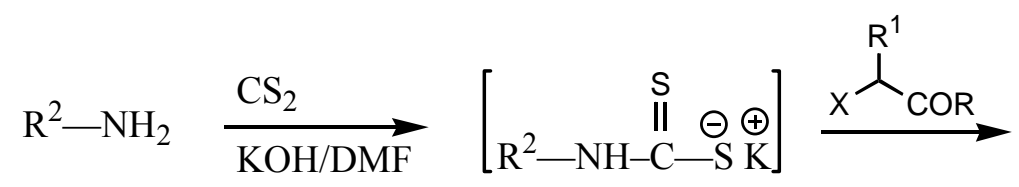<smiles>[R7]NC(=S)SC(CC)C(=O)P</smiles>

134<smiles>[R]c1sc(=S)n([R7])c1[R]</smiles>

135

Various ring systems containing the moiety $-\mathrm{C}(\mathrm{SH})=\mathrm{N}$ - as a part of the ring have been found to condense with $\alpha$-haloketones to yield pyrrolo[2,1-b]thiazoles [330], thiazolo[3,2- $b$ ] isothiazolines [331], thiazolo[3,2-b]-1,2,4-triazoles [332,333], thiazolo[3,2-d]tetrazoles [334], thiazolo[3,2-a]pyridines [335], thiazolo[3,2-a]pyrimidines [336-339], thiazolo[3,2-a]-1,3,5-triazines [340], thiazolo[3,2-b]tetrazines [341-342], and thiazolo[1,2,4]triazepines [343]. Scheme 38 represents an example for preparation of such condensed systems.

\section{Scheme 38}<smiles></smiles>

\section{Synthesis of Five-Membered Rings with Two or Three Miscellaneous Heteroatoms}

4-Aminopyrazoles 140 were prepared in 52-93\% yields via reacting phenylhydrazones 139 with $\alpha$ bromoketones [344]. Also, $N$-phenylpyrazoles 141, could be obtained via the cyclocondensation reaction of phenylhydrazine with $\alpha$-bromoketones (Scheme 39) [345]. 


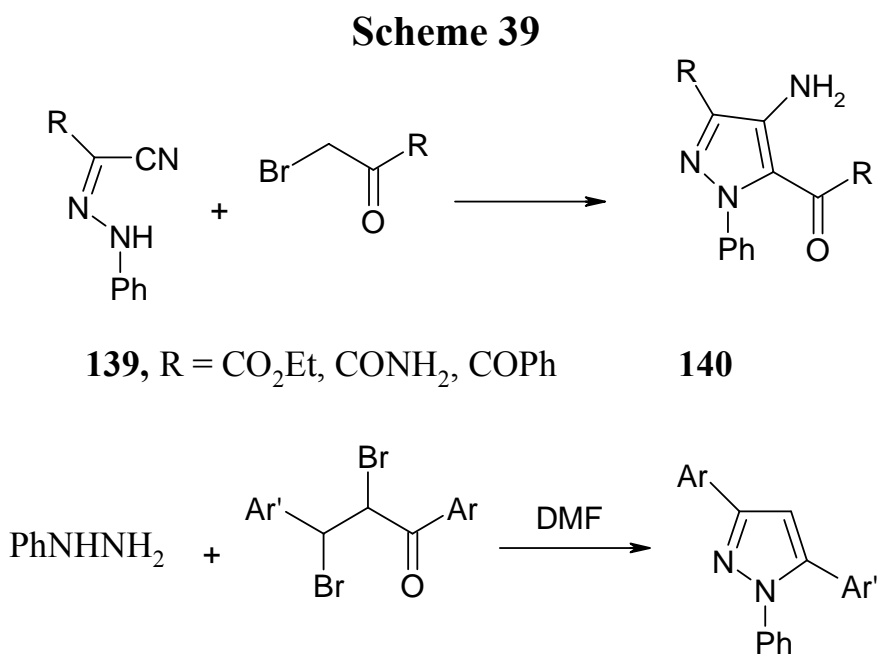

141

2-Aminooxazoles 142 were achieved by a clean, efficient, and economical technology through microwave-induced reaction of phenacyl bromides with urea derivatives on alumina as solid inorganic support [346]. Similar results have been reported by Ulbricht (Scheme 40) [347].

\section{Scheme 40}

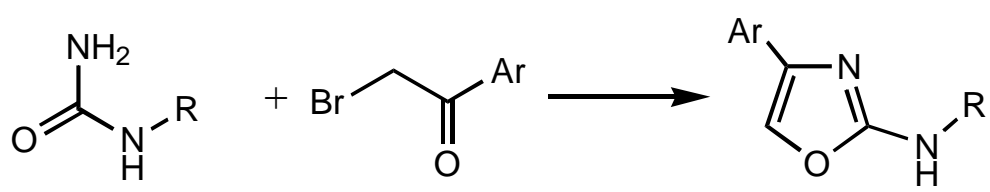

\section{2}

The synthetic methodology of 4,5-diaryloxazoles 145 were improved by Pei et al. [348] using $\alpha$ hydroxyketones 143 as starting materials (Scheme 41) [349-351].

\section{Scheme 41}<smiles>O=C(Br)C(O)Br</smiles>

143<smiles>NC(=O)CC(Cl)C([15N])[Al]</smiles>

144<smiles>[Al]c1ocnc1Br</smiles>

145

Oxazolin-2-ylidenemalononitriles 147 could be obtained from the reaction of thioketeneaminals 146 with $\alpha$-bromoketones (Scheme 42) [352-354]. 


\section{Scheme 42}

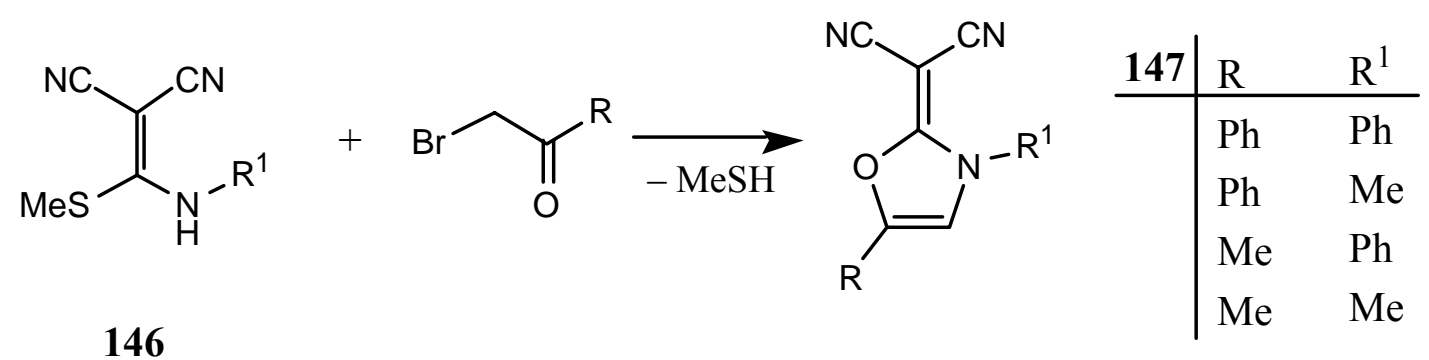

Active chloromethyl ketones e.g. chloroacetone reacted with 2-pyrazoline-4-thiocarboxanilides 148 to give the corresponding 1,3-oxathiol-2-ylidenes 150. It is believed that the reaction proceeds via the sulfide intermediates 149 which spontaneously heterocyclized via loss of ArH (Scheme 43) [355].

\section{Scheme 43}

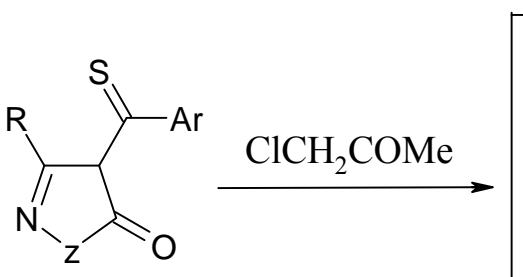

148<smiles>[R]C1=N[Z](=O)C(C)(C2(Br)OC(C)=CS2)C1</smiles>

149

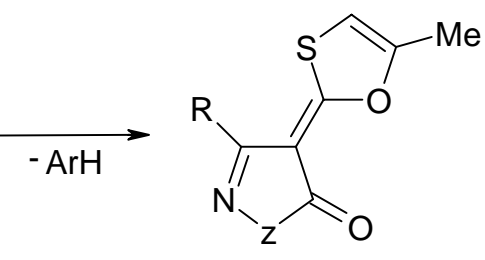

150,Z $=\mathrm{NH}, \mathrm{NPh}$

Reaction of tetrasulfur tetranitride $\left(\mathrm{S}_{4} \mathrm{~N}_{4}\right)$ with aryl and alkyl halomethyl ketones in chlorobenzene gave 3,5-diaroyl and 3,5-diacyl-1,2,4-thiadiazoles 151 in 17-60\% yields (Scheme 44) [356,357].

\section{Scheme 44}

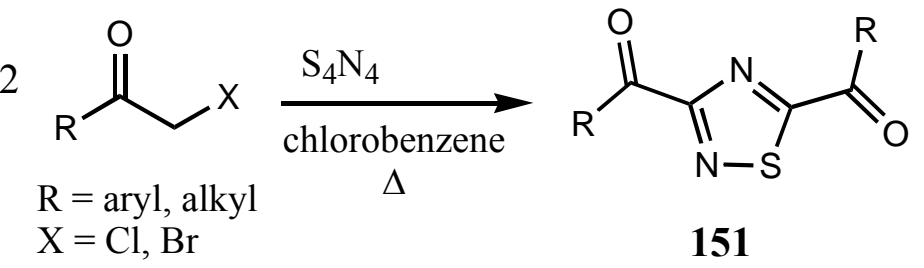

\section{Synthesis of Six-Membered Rings with One Heteroatom}

The literature survey on the reactions of $\alpha$-haloketones with oxygen, nitrogen or sulfur nucleophiles offers a few examples for the synthesis of six-membered heterocycles with one heteroatom. For example, 2-hydroxychalcone dibromides 152 gave 8-bromoflavone 159 on treatment with pyridine. It is assumed that the first stage involved both debromination and dehydrobromination, ring closure and dehydrobromination (Scheme 45) [358]. Similar results have been reported $[359,360]$. 


\section{Scheme 45}

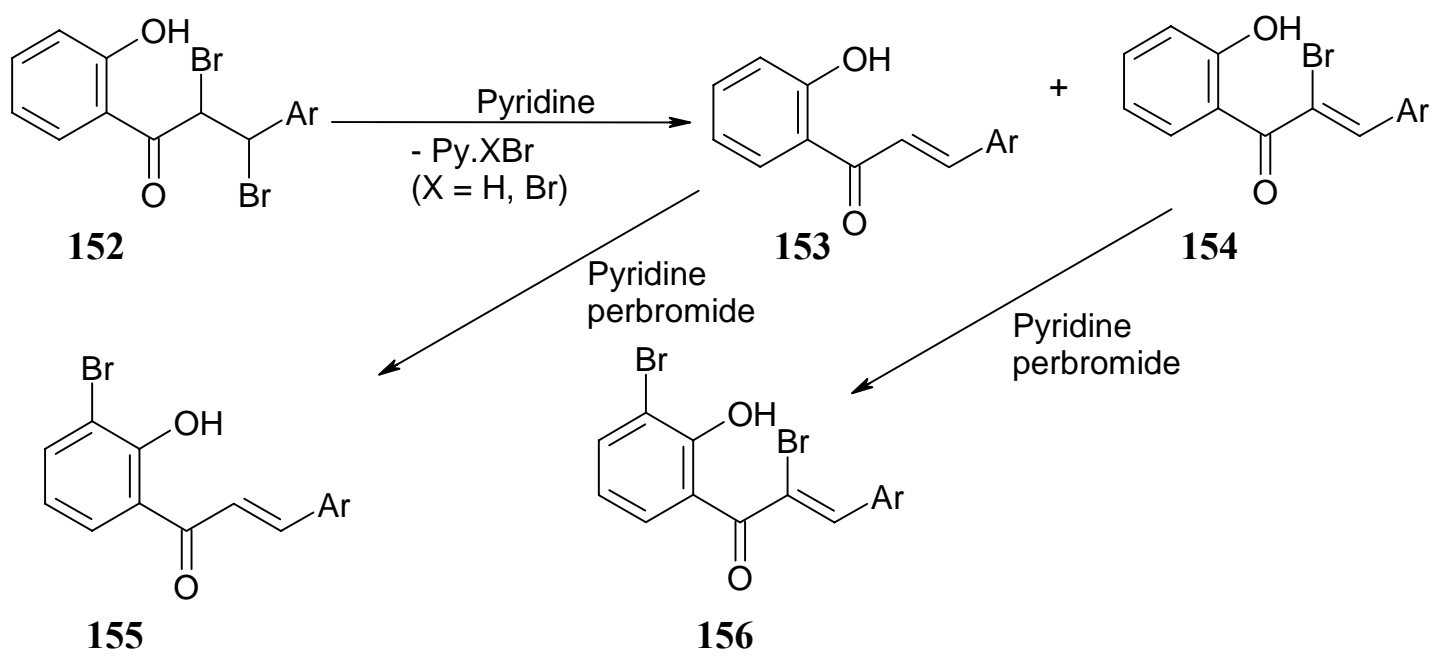<smiles>O=C1CC(Br)Oc2c(Br)cccc21</smiles>

157<smiles>O=C1c2cccc(Br)c2OC(Br)C1Br</smiles>

158<smiles>O=c1cc(Br)oc2c(Br)cccc12</smiles>

159

The synthesis of substituted 1,6-dioxapyrenes 162 from 2,6-dialkyl-1,5-naphthalenediols $\mathbf{1 6 0}$ is described by Christensen and co-workers (Scheme 46) [361].

\section{Scheme 46}

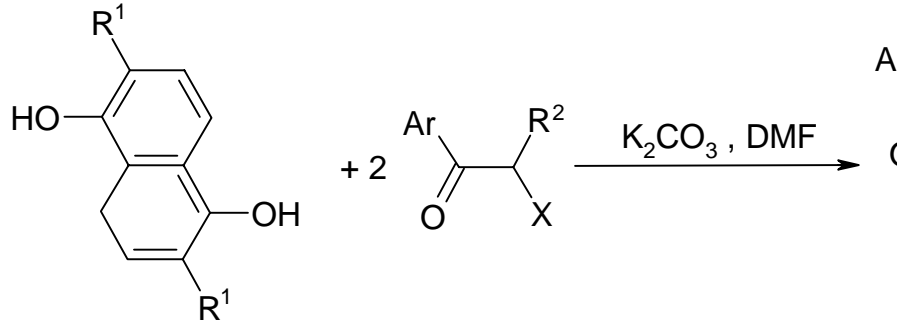

160<smiles>[R]c1ccc2c(OC([R])C(=O)[Al])c([R])ccc2c1OC([R])C(=O)[Al]</smiles>

161

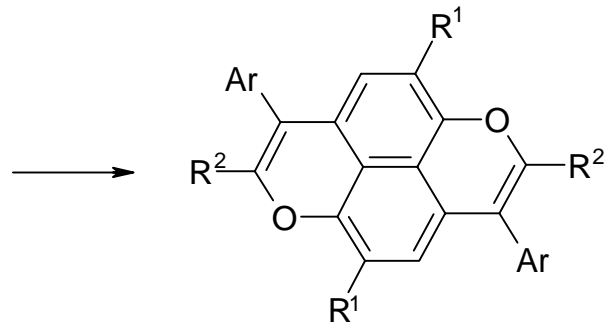


A general synthetic route for 4-aryl-1,2,3,4-tetrahydroisoquinolines 166 was reported from the reaction of aromatic aldehydes $\mathbf{1 6 3}$, methyl amine and $\alpha$-haloacetophenones in the presence of sodium borohydride followed by cyclization with sulfuric acid and zinc in methanol (Scheme 47) [362$365]$.

\section{Scheme 47}

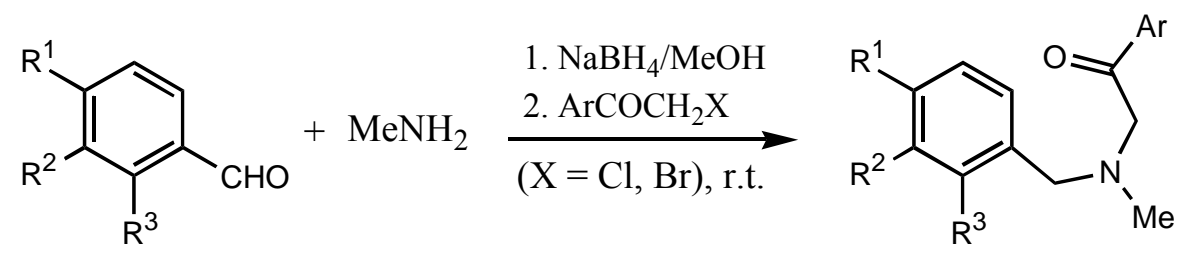

163

164<smiles>[R7]c1c([12F])cc2c(c1[R])CN(C)CC2Br</smiles>

165

166

\section{E. Synthesis of Six-Membered Rings with Two Heteroatoms}

Treatment of 6-hydrazino-1,3-dimethyluracil (167) with phenacyl bromides afforded the corresponding 4-aryl-6,8-dimethylpyrimido[4,5-c]pyridazine derivatives 168 (Scheme 48) [366].

\section{Scheme 48}<smiles>CCCC(=O)CCBr</smiles>

167<smiles>Cn1c(=O)c2c(Br)cnnc2n(C)c1=O</smiles>

168

Reaction of 2-aminoazoles 169 with phenacyl bromides in the presence of dicyclohexylmethylamine gave the corresponding monoalkylated products $\mathbf{1 7 0}$. The latter upon treatment with a strong base afforded fused pyrimidine derivatives 172 (Scheme 49) [367-370]. 


\section{Scheme 49}
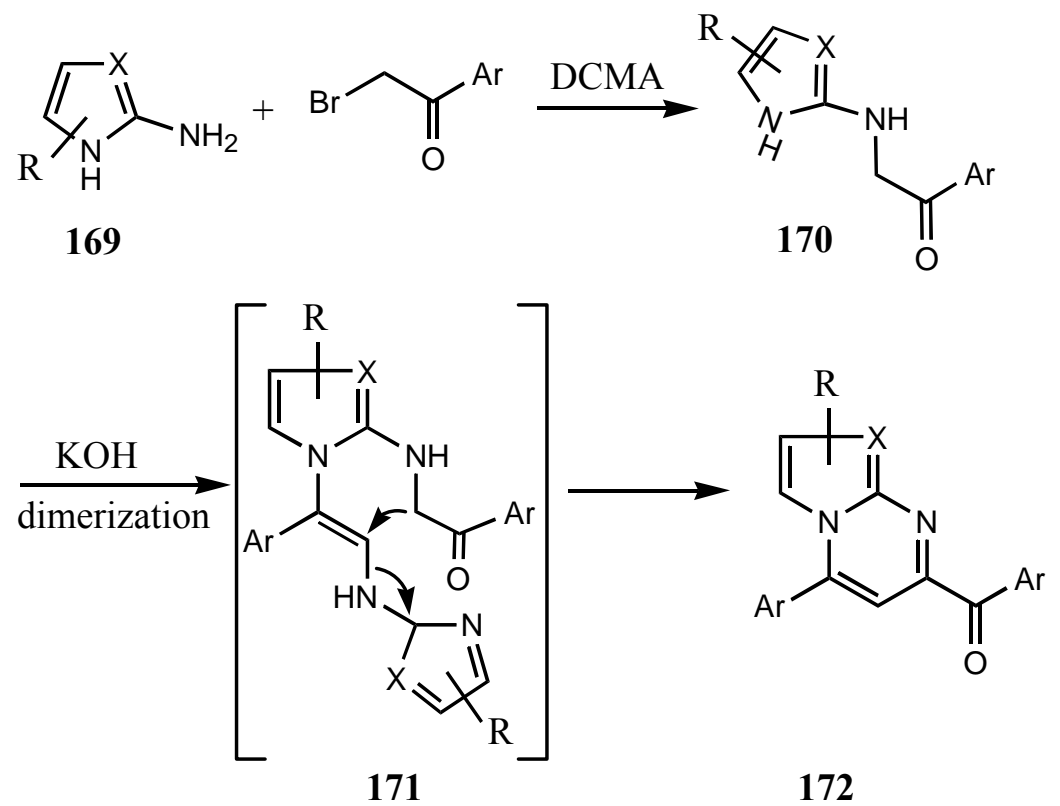

Efficient syntheses of 1,3-thiazines 174 [371] and 1,4-thiazines 176 [372] were achieved via cyclocondensation of $\alpha$-haloketones with the corresponding $N$-substituted thioacyl derivatives $\mathbf{1 7 3}$ and $\mathbf{1 7 5}$, respectively (Scheme 50).

\section{Scheme 50}<smiles>[R]C(=O)CCl</smiles><smiles>[R]C1=Nc2c(c(=O)n(C)c(=O)n2C)SC1</smiles>

Several pyrazines [373-381], oxazines [382-385], and thiazines [386-393] were obtained when 177 were treated with $\alpha$-haloketones (Scheme 51). 


\section{Scheme 51}

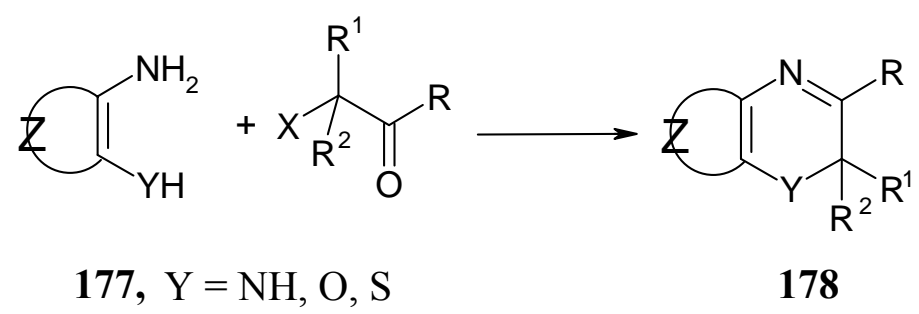

The dimerization of the phenacyl derivatives 179, readily obtainable from $\alpha$-haloketones and amines, $\mathrm{NaOH}$ or Lawesson's reagent, is one of the convenient synthetic route for the preparation of pyrazine [394-398], 1,4-dioxin [399-401] and 1,4-dithiin [402,403] derivatives 180 (Scheme 52).

\section{Scheme 52}<smiles>[Y]CC([R])=O</smiles>

179, $\mathrm{Y}=\mathrm{NH}, \mathrm{O}, \mathrm{S}$<smiles>[R]c1[Y]c[Y]2cc([R])c[Y]:2c1</smiles>

180

\section{F. Synthesis of Six-Membered Rings with Three Heteroatoms}

The reaction of 4-substituted thiosemicarbazides 181 with $\alpha$-bromoacetophenones in $2 M$ hydrochloric acid initially provide the corresponding thiosemicarbazones $\mathbf{1 8 2}$, followed by cyclization to 2-amino-5-aryl-6H-1,3,4-thiazines 183 upon boiling in ethanol (Scheme 53) [404-406].

\section{Scheme 53}<smiles>[R]NC(=S)N[NH3+]</smiles>

181

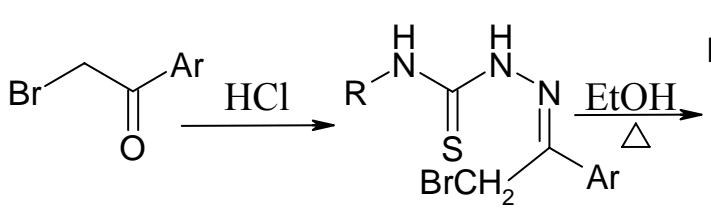

182<smiles>NC1=NN=C(Br)CS1</smiles>

183, $\mathrm{R}=\mathrm{Me}, \mathrm{Ph}$

A number of 4H-1,2,4-triazino[3,4-c]-1,4-benzoxazines $\mathbf{1 8 6}$ could be prepared as antiinflammatory agents via the $N$-alkylation of benzoxazines 184 with $\alpha$-bromoacetophenones to give 185 which cyclized with hydrazine hydrate to give 186 (Scheme 54) [407]. 


\section{Scheme 54}<smiles>[R]c1ccc2c(c1)NC(=O)CO2</smiles>

184<smiles>O=C(Br)CBr</smiles>

185<smiles>[R]c1ccc2c(c1)N1CC([Al])=NN=C1CO2</smiles>

186; $\mathrm{R}=\mathrm{H}, \mathrm{Cl}, \mathrm{Me}$

Several pyridooxadiazines [408], imidazo[2,1-b]thiadiazines [409], thiazolo[2,3- $b]-1,3,4-$ thiadiazines [410,411], triazolothiadiazines [412-421], pyrimido[2,1-b]thiadiazines [422-424], thiazolo[3,4-c]-1,2,4-triazines [425], and pyrimido[2,1-c]-as-triazines [426,427] $\mathbf{1 8 8}$ were obtained via the cyclocondensation of $\alpha$-haloacetophenones with 1-amino-2-pyridones, 1aminobenzimidazoline-2-thiones, 3-amino-thiazoline-2-thiones, 3-mercapto-1,2,4-triazoles, 1-amino2(1H)-pyrimidinethiones, 4-phenylhydrazino-2-thiazolidenethiones and 2-hydrazinopyrimidines, respectively (Scheme 55).

\section{Scheme 55}<smiles>[Y]C1=CCCCN1N</smiles>

187<smiles></smiles>

188, $\mathrm{Y}=\mathrm{O}, \mathrm{S}, \mathrm{NH}$

$\mathrm{Z}=\mathrm{CH}, \mathrm{NH}, \mathrm{S}$

\section{G. Synthesis of Miscellaneous Heterocyclic Rings}

Trans-aziridines 190 were formed from the reaction of $\alpha, \beta$-dibromoketones 189 with ammonia (Scheme 56) [428].

\section{Scheme 56}<smiles>N[13CH2]N</smiles>

189<smiles>O=C(Br)[C@@H]1N[C@@H]1[17Br]</smiles>

190 
Tertiary amides 193 were converted into the dianions 194, when treated with 2 equivalent of $n$-butyl lithium, which were oxidized with $\mathrm{N}$-iodosuccinimide (NIS) to form the corresponding $\beta$-lactams 195 (Scheme 57) [429,430].

\section{Scheme 57}<smiles>CCCCC(C)N(CC(=O)c1ccccc1)c1ccc(OC)cc1</smiles><smiles>[R]CC(=O)N(CC(=O)c1ccccc1)c1ccc(OC)cc1</smiles>

193

194

195; $\mathrm{R}=\mathrm{H}, \mathrm{Et}, \mathrm{MeO}$

Attempted dehydrohalogenation of $\alpha$-bromo- $\alpha$-methylaminoketones 196 using sodium amide in liquid ammonia yielded the corresponding $\beta$-lactams 199 (Scheme 58) [431].

Scheme 58<smiles>[Y]NC1([R])CCCC(Br)C1=O</smiles>

196

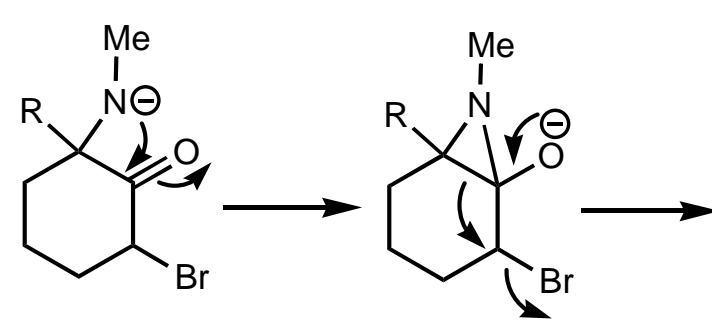

197

198<smiles>[R]C12CCCC1C(=O)N2C</smiles>

199

The heterocyclization of 3-aminopropenethioamides $\mathbf{2 0 0}$ with 2-bromoacetophenone in the presence of a catalytic amount of $p$-toluenesulfonic acid in chloroform at reflux gives a direct route to 1,4-thiazepines 202 (Scheme 59) [432,433]. 


\section{Scheme 59}

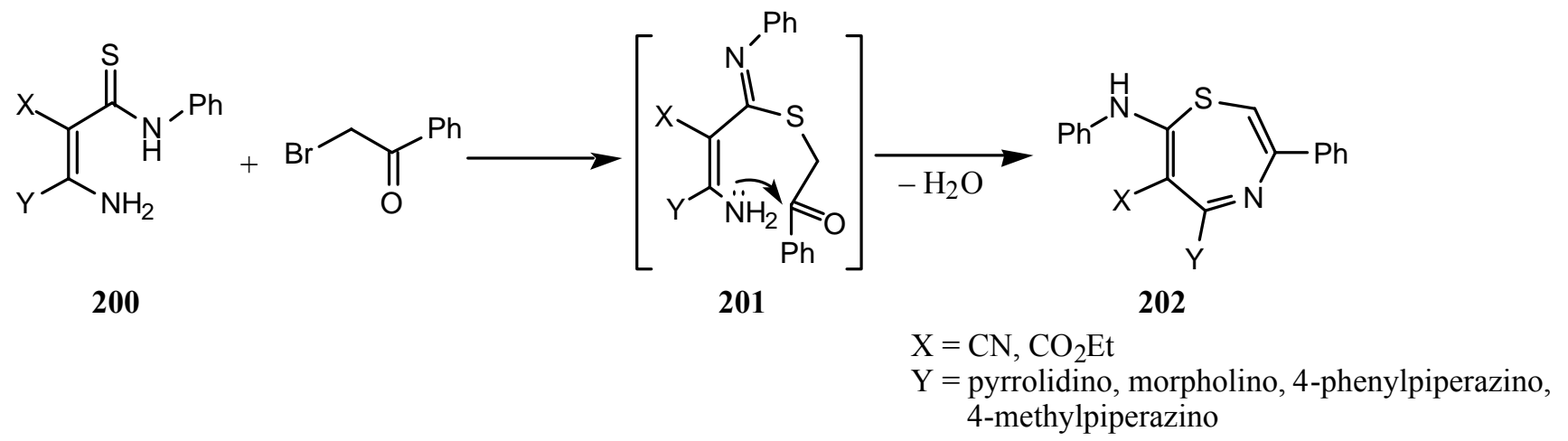

Tetrahydro-1,4-benzothiazepines 206 and 207 were prepared via ring expansion of the 1,3-benzothiazine derivative 203. The suggested mechanism could be as depicted in Scheme 60 [434,435].

\section{Scheme 60}

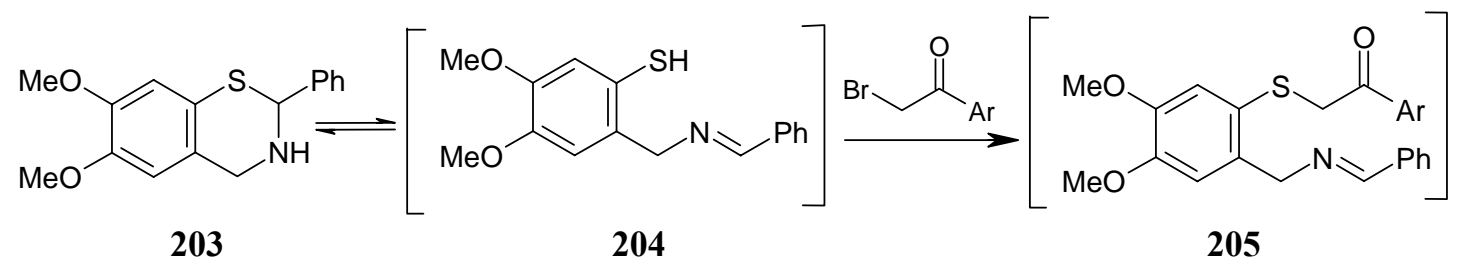

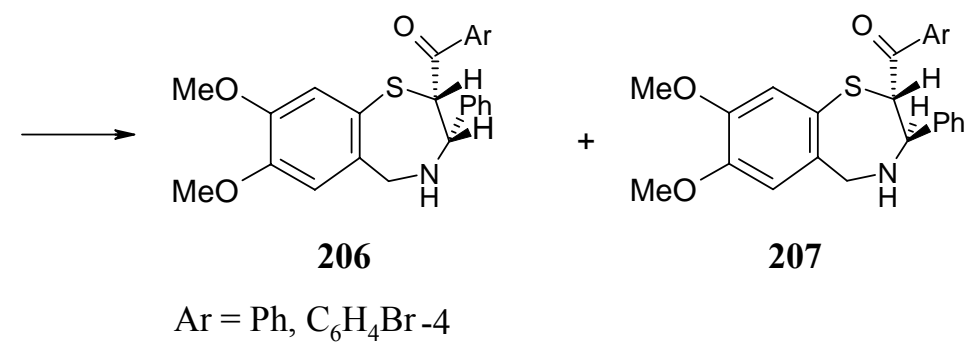

The hydroxybenzyl group in the 1,2,5,6-tetrahydropyridine derivatives $\mathbf{2 1 0}$ initiated the intramolecular cyclization reactions to provide racemic endo-exo isomers of 4,6-diaryl-1azabicyclo[3.2.1]-oct-3-ene derivatives 211 and 212 (Scheme 61) [436,437]. 


\section{Scheme 61}
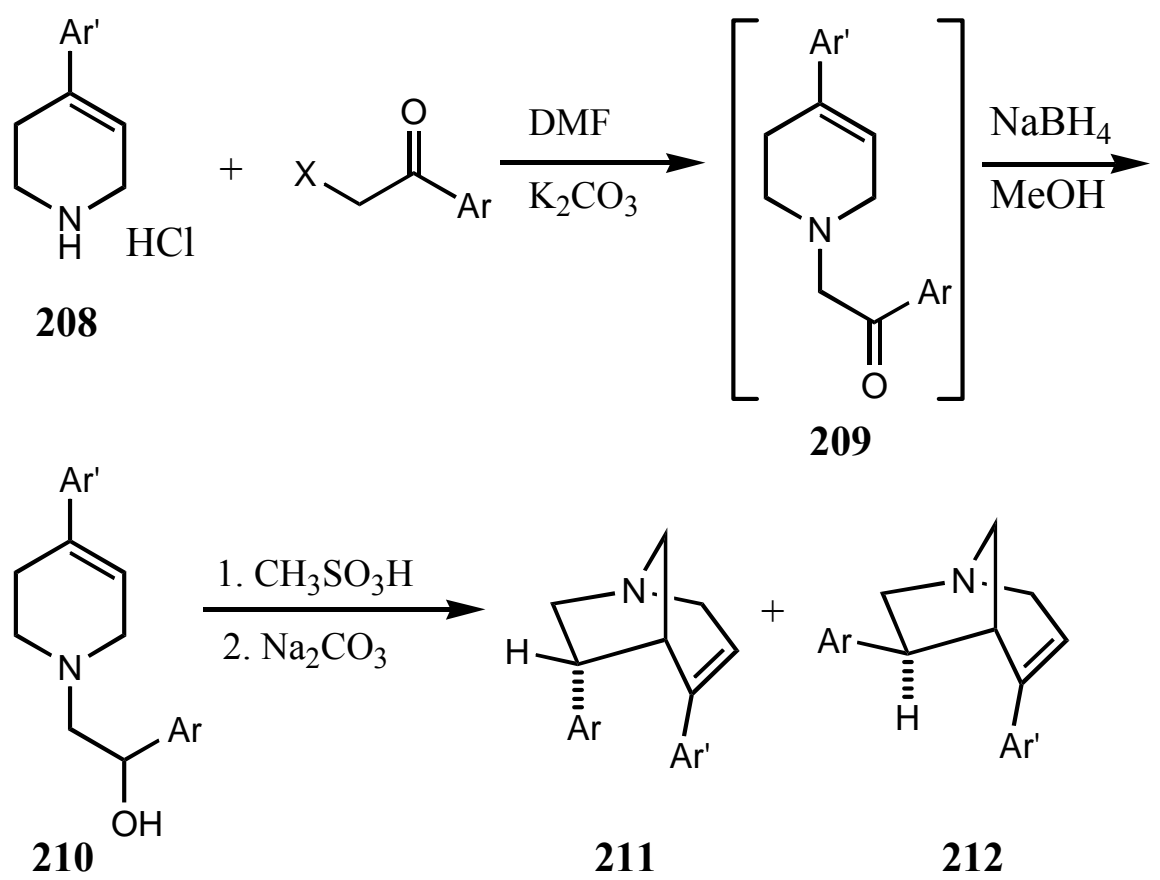

\section{Reactions of $\alpha$-Haloketones with Carboxylic Acids and Their Derivatives}

$\alpha$-Haloketones react with carboxylic acid salts to give substituted ester products 213 . Hydrolysis of these esters affords the corresponding $\alpha$-hydroxyketones 214. No major side products were reported (Scheme 62) [438-448].

\section{Scheme 62}
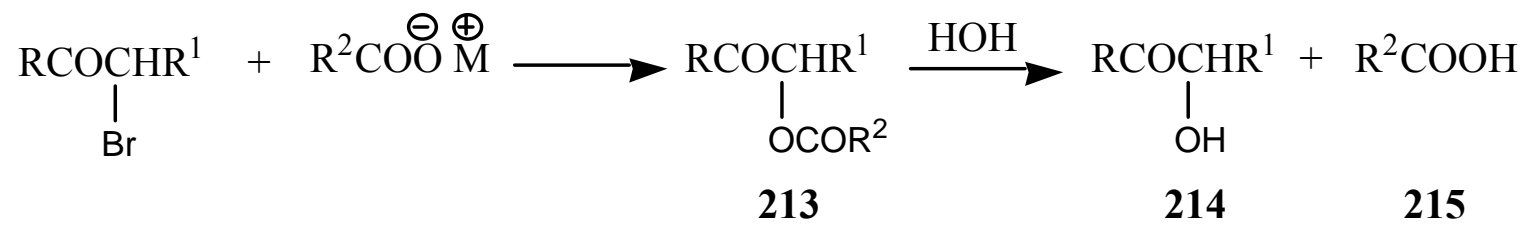

$\alpha$-Bromoketones react with bromoacetic acid in the presence of a catalytic amount of triethylamine to give the substitution products 216, which, via the intermediate phosphonium salts 217, heterocyclized to the corresponding $\alpha, \beta$-unsaturated lactones 218 (Scheme 63) [449]. 


\section{Scheme 63}

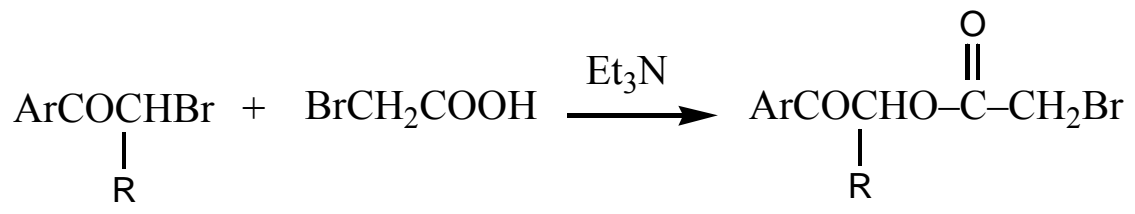

216

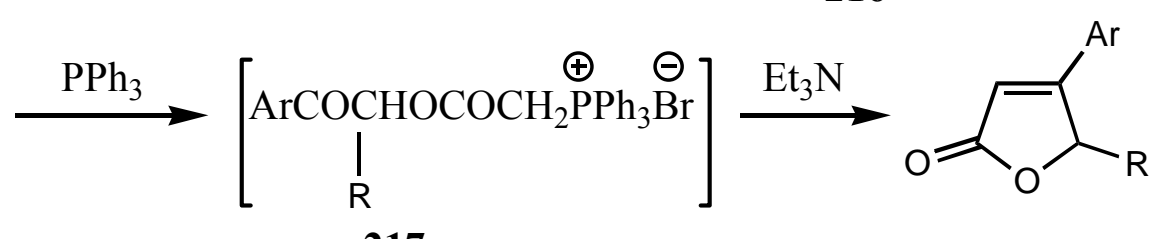

217

218

The oxazole derivatives 221 could be obtained via reaction of $\alpha$-bromoketones with the sodium salts of carboxylic acids in the presence of ammonium acetate. The oxazole derivatives 221 show some analgesic activity (Scheme 64) [450,451].

\section{Scheme 64}

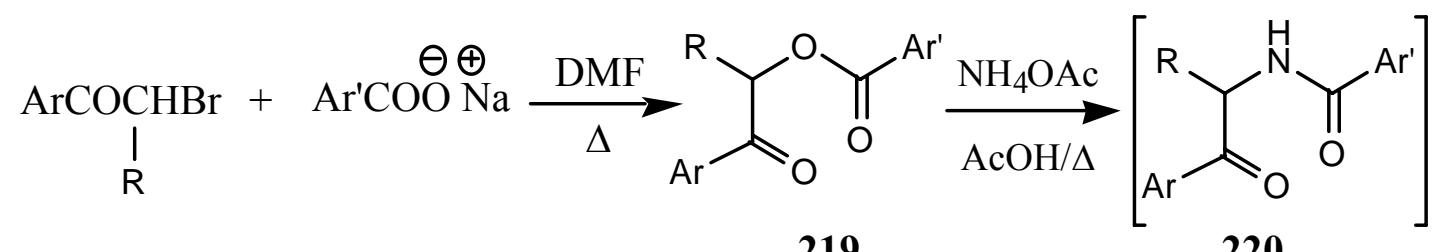

219 220

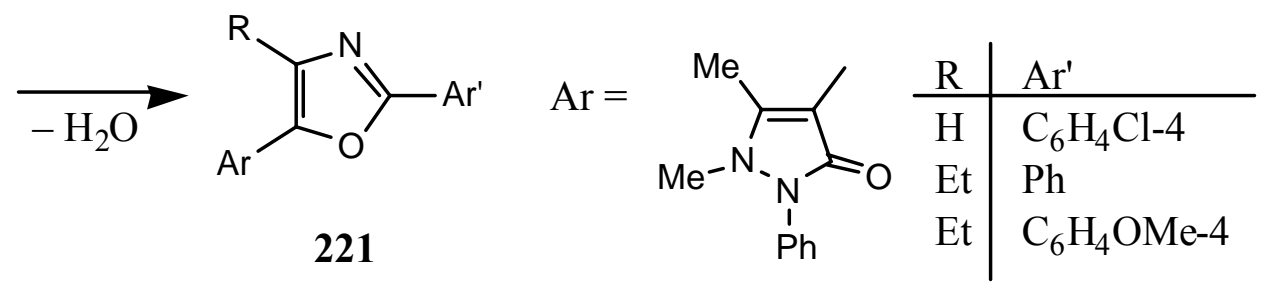

Thiocarboxylic acids and their derivatives react readily with $\alpha$-bromoketones. The reaction of $\alpha$ bromoketones with thioacids in the presence of ammonium acetate in refluxing acetic acid affords the 1,3-thiazole derivatives 222 (Scheme 65) [452-455].

\section{Scheme 65}

$$
\underset{\mathrm{Br}}{\mathrm{R}^{1} \mathrm{COCHR}^{2}}+\mathrm{R}^{3}-\stackrel{\mathrm{I}}{\mathrm{C}}-\mathrm{SH} \underset{\mathrm{AcOH} / \Delta}{\stackrel{\mathrm{NH}_{4} \mathrm{OAc}}{\longrightarrow}}
$$<smiles>[R]c1nc([R])c([R])s1</smiles>

222

The reaction of $o$-acylbenzoic acids 223 with $\alpha$-bromoacetophenones in the presence of $\mathrm{K}_{2} \mathrm{CO}_{3}$ affords benzopyran-1H-1-one derivatives 225. The pyranones 225 show, in vivo, significant blood pressure effect on rats (Scheme 66) [456-460]. 


\section{Scheme 66}<smiles>[R]C(=O)c1ccccc1C(=O)O</smiles>

223<smiles>[R]C(=O)c1ccccc1C(=O)OCC(=O)Br</smiles>

224<smiles>[R]c1c(C(=O)[Al])oc(=O)c2ccccc12</smiles>

225

1,2-Disubstituted-3-hydroxy-4(1H)-quinolinones $\mathbf{2 2 8}$ were prepared by the reaction of potassium salts of anthranilic acids 226 with $\alpha$-haloketones to give the corresponding acetonyl or phenacyl anthranilates 227. On heating with polyphosphoric acid, the latter compounds afford 228 (Scheme 67) $[461,462]$.

\section{Scheme 67}<smiles>[Y]CC([R])=O</smiles>

226

227<smiles>[R7]c1c(O)c(=O)c2ccccc2n1[R10]</smiles>

5-Aryl-3,6-dihydro- $2 H$-1,4-oxazin-2-ones 230 were synthesized via reacting the potassium salts of $\alpha$-amino acids 229 with $\alpha$-bromoacetophenones (Scheme 68) [441-463].

\section{Scheme 68}

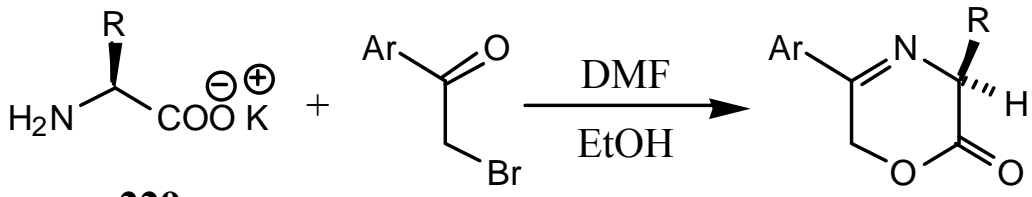

229

230

$S$-Potassium hydrazinomonothio- and dithioformates 231 react with $\alpha$-haloketones to give acylmethyl (hydrazino)thioformates 232. The latter can be cyclized to 1,3-thiazolines 233 or 1,3,4thiadiazines 234 depending upon the substitution pattern of the ketone (Scheme 69) [464]. 


\section{Scheme 69}

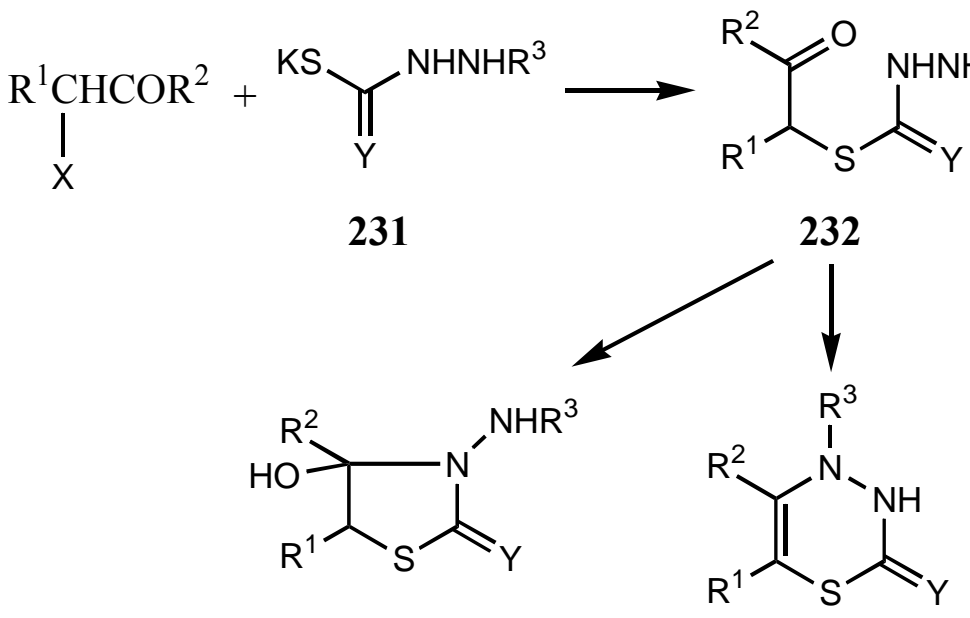

233

\section{Reactions of $\alpha$-Haloketones with Carbon Nucleophiles}

$\alpha$-Haloketones may undergo two competitive reactions with sodium or potassium cyanide. Nucleophilic addition and intramolecular substitution lead to 2-cyanooxiranes 235 [465-479] (Scheme 70).

Scheme 70

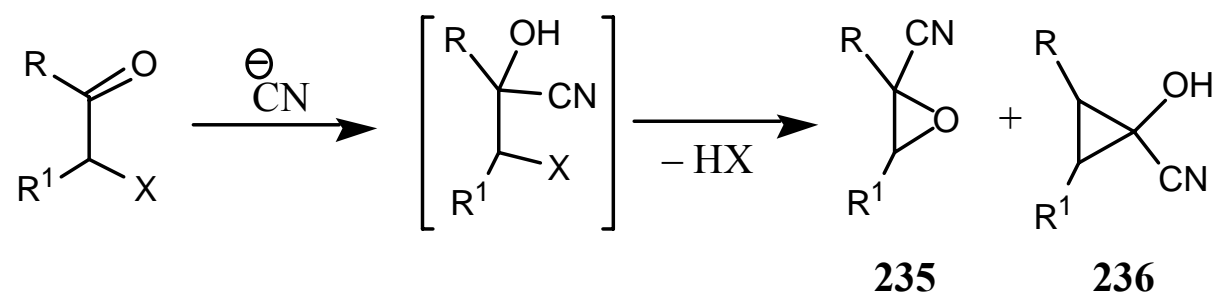

Whereas Favorskii rearrangement and nucleophilic addition generate cyanocyclopropanols 236 $[471,473,474]$ depending on the solvent and the reaction conditions. A typical example for Favorskiitype rearrangement is obtained on reaction of 1-chloro-3-phenyl-2-propanone (237) with alkali cyanides to yield the cyclopropane derivative $\mathbf{2 4 0}$ (Scheme 71) [480]. 


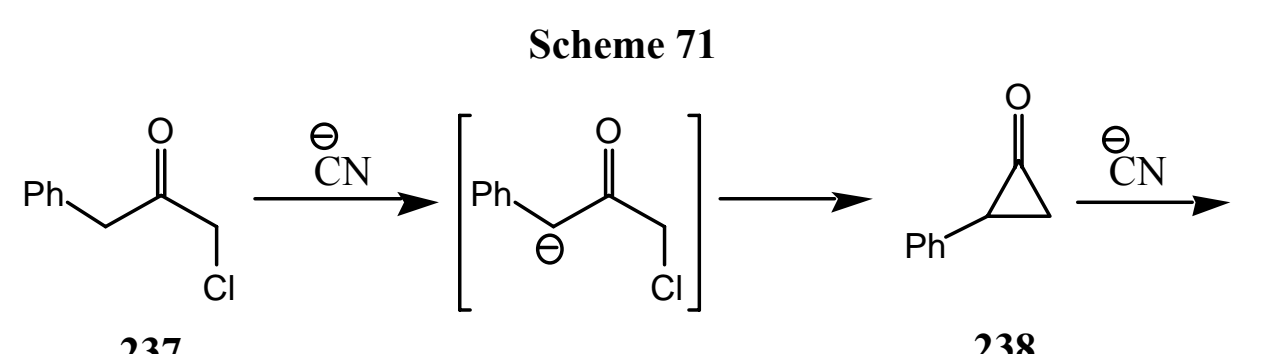

237

238

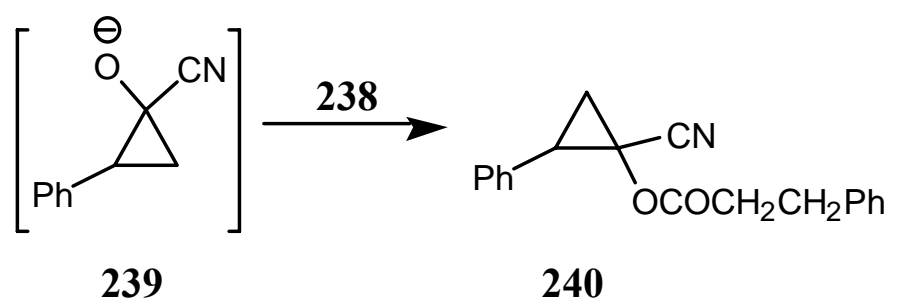

Condensation of $\alpha$-haloketones with each of $\beta$-keto esters 241 and dimedone (243) affords the corresponding furans 242 [481] and 6,6-dimethyl-4-oxo-4,5,6,7-tetrahydrobenzofurans 245 , respectively (Scheme 72) [482-486].

Scheme 72

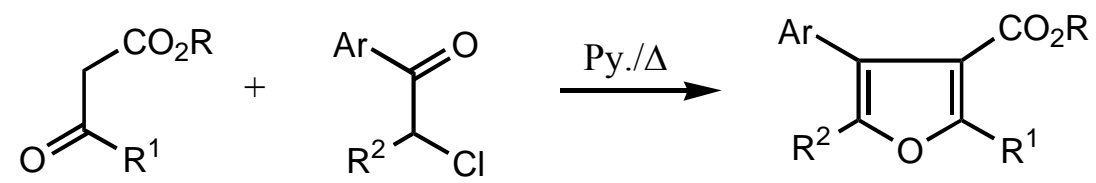

241

242<smiles>[R]C(=O)CC1(C)CC(=O)CC([CH+])(C)C1</smiles>

243<smiles>[R]C(=O)CC1C(=O)CC(C)(C)CC1=O</smiles>

244

245

Treatment of cyclic or acyclic $\alpha$-haloenones 246 with various carbon nucleophiles involving active methylene functions, under PTC conditions, afforded the corresponding dihydrofurans 249 (Scheme 73) $[487,488]$. 


\section{Scheme 73}

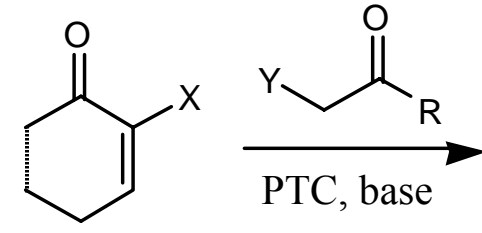

246 $\mathrm{C}-\mathrm{C}$ bond
formation<smiles>[R]C(=O)C([Y])C1CCCC([O-])=C1[X]</smiles>
247<smiles>[R]C1=C([Y])C2CCCC(=O)C2O1</smiles>

249

C-O bond formation<smiles>[Y]C([R])=C([Y])C1CCCC(=O)C1[X]</smiles>

248

$\mathrm{Y}=$ electron withdrawing group

The reaction of $\alpha$-bromoacetophenones with malononitrile (250) affords 2-amino-3-cyanofuran derivatives 251. This reaction, aimed at heterocyclic synthesis of furans and their fused systems, was first reported by Gewald and subsequently explored by other groups (Scheme 74) [490-501].

\section{Scheme 74}

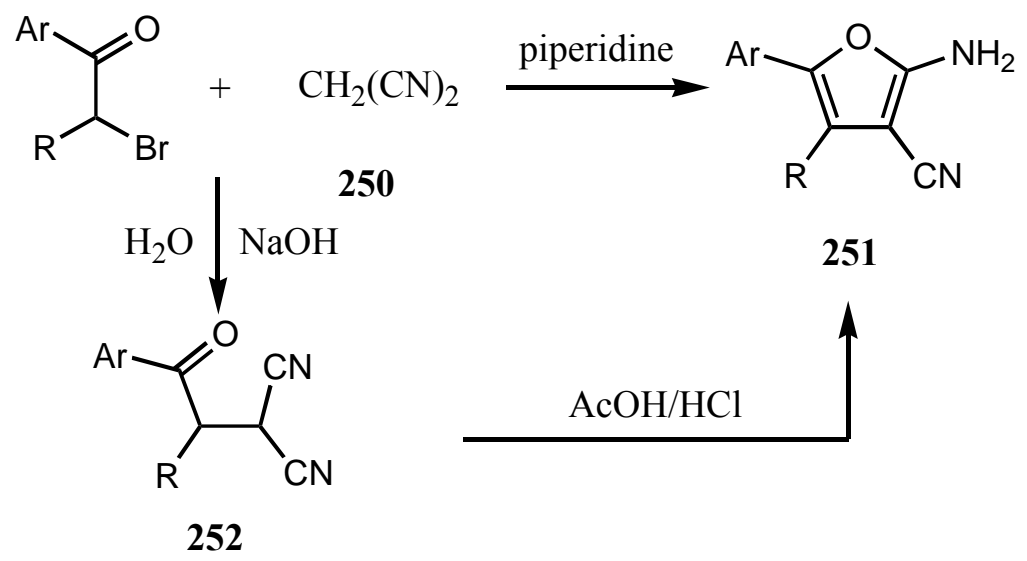

Dilithio-2,4-oxa(thia)zolidinediones 253 coupled with $\alpha$-haloketones to give the allylic derivatives 254 which upon alkaline hydrolysis afford the corresponding 2-(5H)-furanones 255 (Scheme 75) [502-505]. 


\section{Scheme 75}<smiles>[R16][Y6]O[S-]</smiles>

The sodium derivatives of 1,3-dialkylbarbituric acid or 2-thiobarbituric acid derivatives 256 undergo monoacylation at $\mathrm{C}-5$ to give the corresponding 5-chloroacetyl derivatives 258 which cyclized on treatment with $\mathrm{Et}_{3} \mathrm{~N}$ in ethanol to give the corresponding furano[3,2-e]pyrimidindione derivatives 259 (Scheme 76) [506].

\section{Scheme 76}

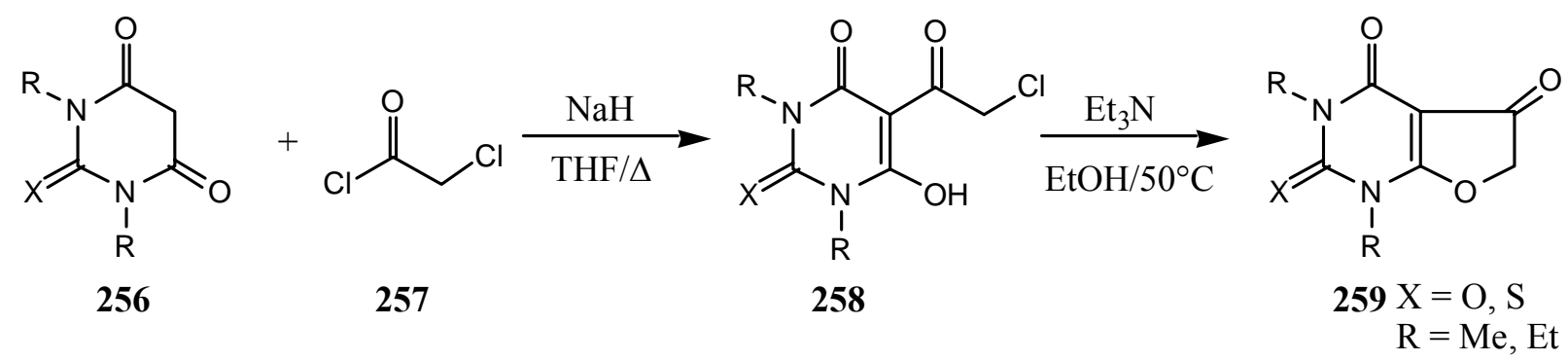

7-Methyl-6-phenyl-2,4-di-1-pyrrolidinyl-7H-pyrrolo[2,3-d]pyrimidine (262), used as a potent antioxidant (PNU-87663), could be synthesized via reaction of the pyrimidine derivative $\mathbf{2 6 0}$ with phenacyl bromide [507,508]. The active methylene group in 1,1-dicyano-2-phenyl-3-phenylsulfonylpropene (263) reacted with phenacyl bromide in the presence of potassium tert-butoxide to give the corresponding cyclopentadiene derivative 265 (Scheme 77) [509].

Scheme 77
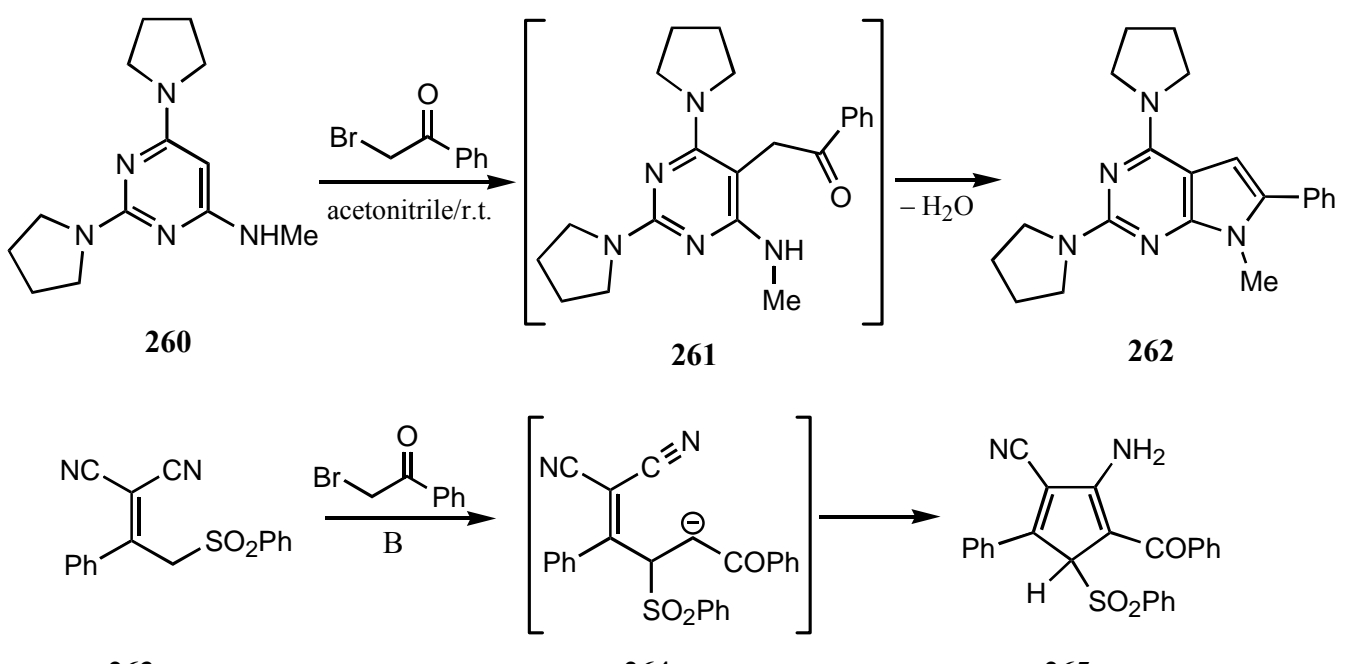
The reaction of alkyl and aryl $\alpha$-halomethyl ketones with aliphatic or aromatic nitriles $\mathbf{2 6 6}$ in the presence of trifluoromethanesulfonic anhydride in dichloromethane affords the corresponding halopyrimidines 267 (Scheme 78) [510].

\section{Scheme 78}

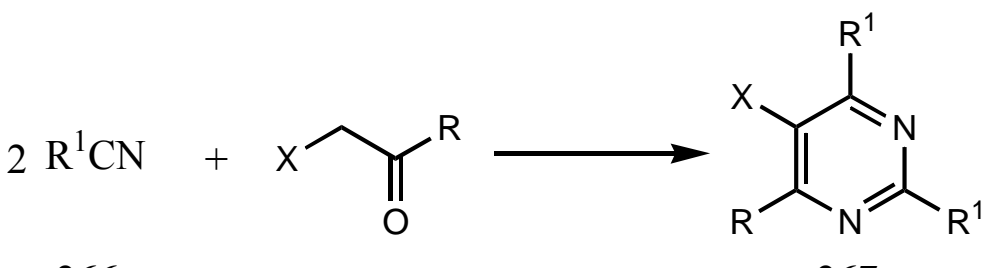

266

267

$\mathrm{R}=\mathrm{Me}, \mathrm{Ph} ; \mathrm{R}^{1}=\mathrm{Me}, \mathrm{Ph} ; \mathrm{X}=\mathrm{Cl}, \mathrm{Br}, \mathrm{I}$

\section{Reactions of $\alpha$-Haloketones with Alkenes and Alkynes}

3-Acyl-2H-1-benzopyran-2-ones 268 reacted with phenacyl bromide in the presence of a base to give the cyclopropane derivatives 271 and 272 in moderate yields via intermediates 269 and 270 [511-518]. The mechanism and the steroselectivity of such reactions have been well-studied (Scheme 79) $[511]$.

\section{Scheme 79}

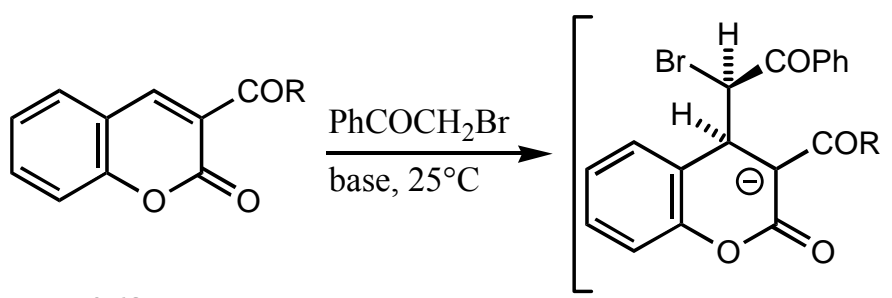

268
269

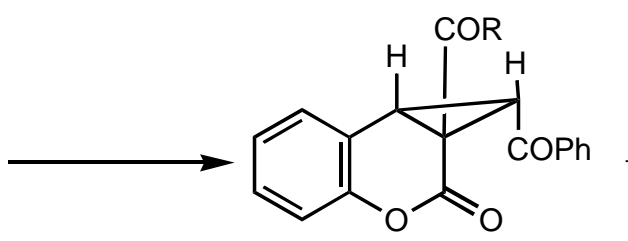

271<smiles>O=C(O)C1C(=O)Oc2ccccc2[C@H]1Cc1ccccc1</smiles>

270

$\mathrm{R}=\mathrm{Me}, \mathrm{Et}, \mathrm{CH}(\mathrm{Me})_{2}, \mathrm{C}(\mathrm{Me})_{3}, \mathrm{Ph}, \mathrm{OMe}, \mathrm{OEt}, \mathrm{OC}(\mathrm{Me})_{3}$

The palladium-catalyzed reaction of $\alpha$-haloketones with allyl-substituted tin compounds such as diallyldibutyltin (273) is a useful route to 2-allyloxirans 274 [519-522]. The allylation of 2-chlorocyclohexan-1-one (52) gave the corresponding cis-1-allyl-2-chlorohexanol 276 (Scheme 80) [521]. 


\section{Scheme 80}

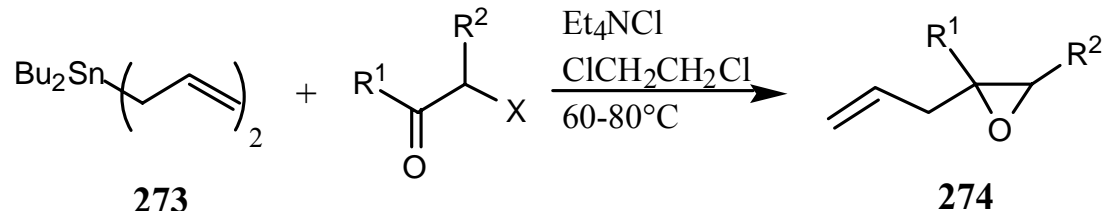<smiles>C=CC[C@]1(O)CCCC[C@H]1Cl</smiles>

By catalytic use of rhenium(I) nitrogen complex, $\left[\mathrm{ReCl}\left(\mathrm{N}_{2}\right)\left(\mathrm{PMe}_{2} \mathrm{Ph}\right)_{4}\right], \alpha$-keto radicals, generated from $\alpha$-bromoketones react with vinyl ethers 277 to give 2,5-diarylfurans 279 via 278 (Scheme 81) $[523,524]$.

\section{Scheme 81}

$\overbrace{\mathrm{Ph}}^{\mathrm{OMe}}+\mathrm{Br} \prod_{\mathrm{O}}^{\mathrm{Ar}} \frac{\left[\mathrm{ReCl}\left(\mathrm{N}_{2}\right)\left(\mathrm{PMe}_{2} \mathrm{Ph}\right)_{4}\right]}{\mathrm{DMF}, 130^{\circ} \mathrm{C}}$

277, $\mathrm{R}=\mathrm{H}, \mathrm{Me}$<smiles>[R]c1cc([Al])oc1-c1ccccc1</smiles>

278

279

Effective coupling of organotin(IV) enamines $\mathbf{2 8 0}$ with $\alpha$-haloketones gave the corresponding 2,4disubstituted pyrroles $\mathbf{2 8 1}$ at room temperature even under aqueous conditions (Scheme 82) [525532].

\section{Scheme 82}

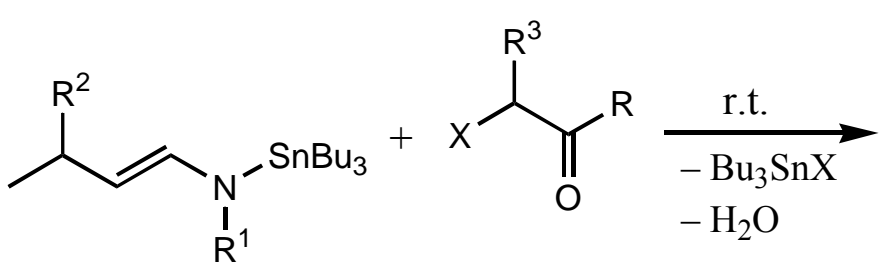

280<smiles>[R]c1c(C([R])C)cn([R7])c1[R]</smiles>

281

$N$-(1-Phenylvinyl)iminophosphoranes $\mathbf{2 8 2}$ reacted with $\alpha$-bromoketones to give substituted pyrroles $\mathbf{2 8 3}$ via $\mathrm{C}-\mathrm{C}$ bond formation followed by an aza-Wittig reaction (Scheme 83) [533-535]. 


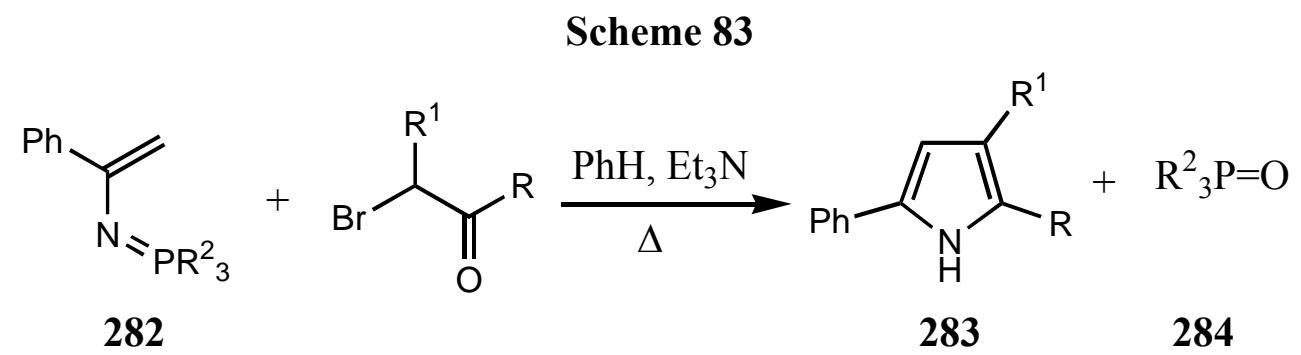

Methyl 3-amino-3-arylazopropenates $\mathbf{2 8 5}$ react with $\alpha$-haloketones in the presence of 1,8-diazabicyclo[5.4.0]undec-7-ene (DBU) to furnish the pyrrole derivatives 286 on the pattern of the Hantzchpyrrole synthesis (Scheme 84) [536,537].

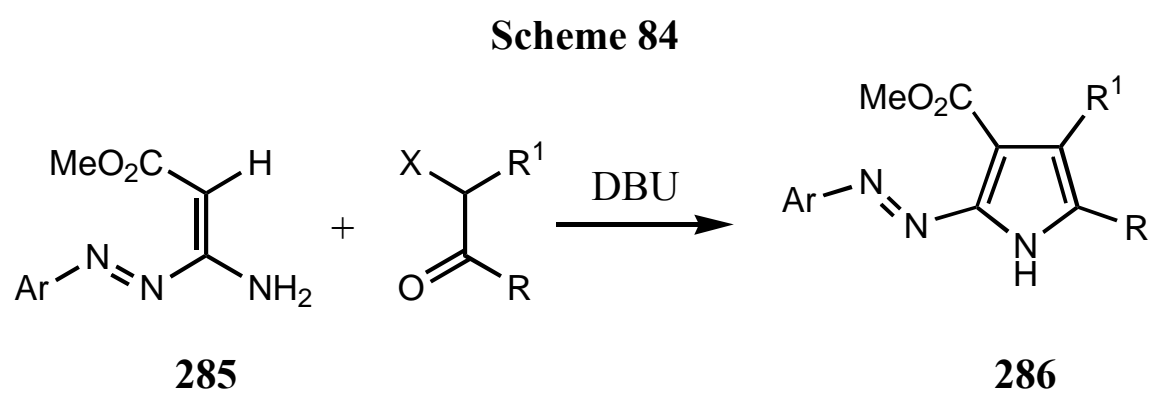

The preparation of 1-phenacylcyclohexan-1,4-dione mono(ethyleneketal) (289) was achieved by alkylation of the pyrrolidine enamine $\mathbf{2 8 8}$ with phenacyl bromide. The latter could be cyclized by the effect of ammonium carbonate, as the source of nitrogen to give 2-phenyl-4,5,6,7-tetrahydroindol-5one (291) (Scheme 85) [538,539].

\section{Scheme 85}

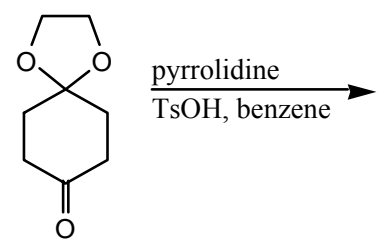

287

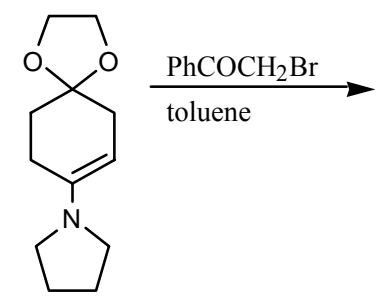

288

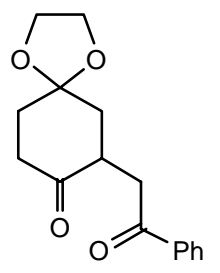

289

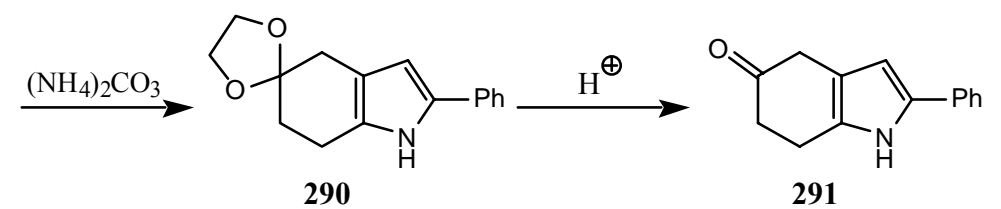

Reaction of $\alpha, \alpha^{\prime}$-dihaloketones with a variety of metal complexes especially $\mathrm{Fe}_{2}(\mathrm{CO})_{9}$, generates oxyallyl cations 292. The latter undergo ring closure with alkenes to various carbocycles and heterocycles 293-298 (Scheme 86) [540-544]. 


\section{Scheme 86}

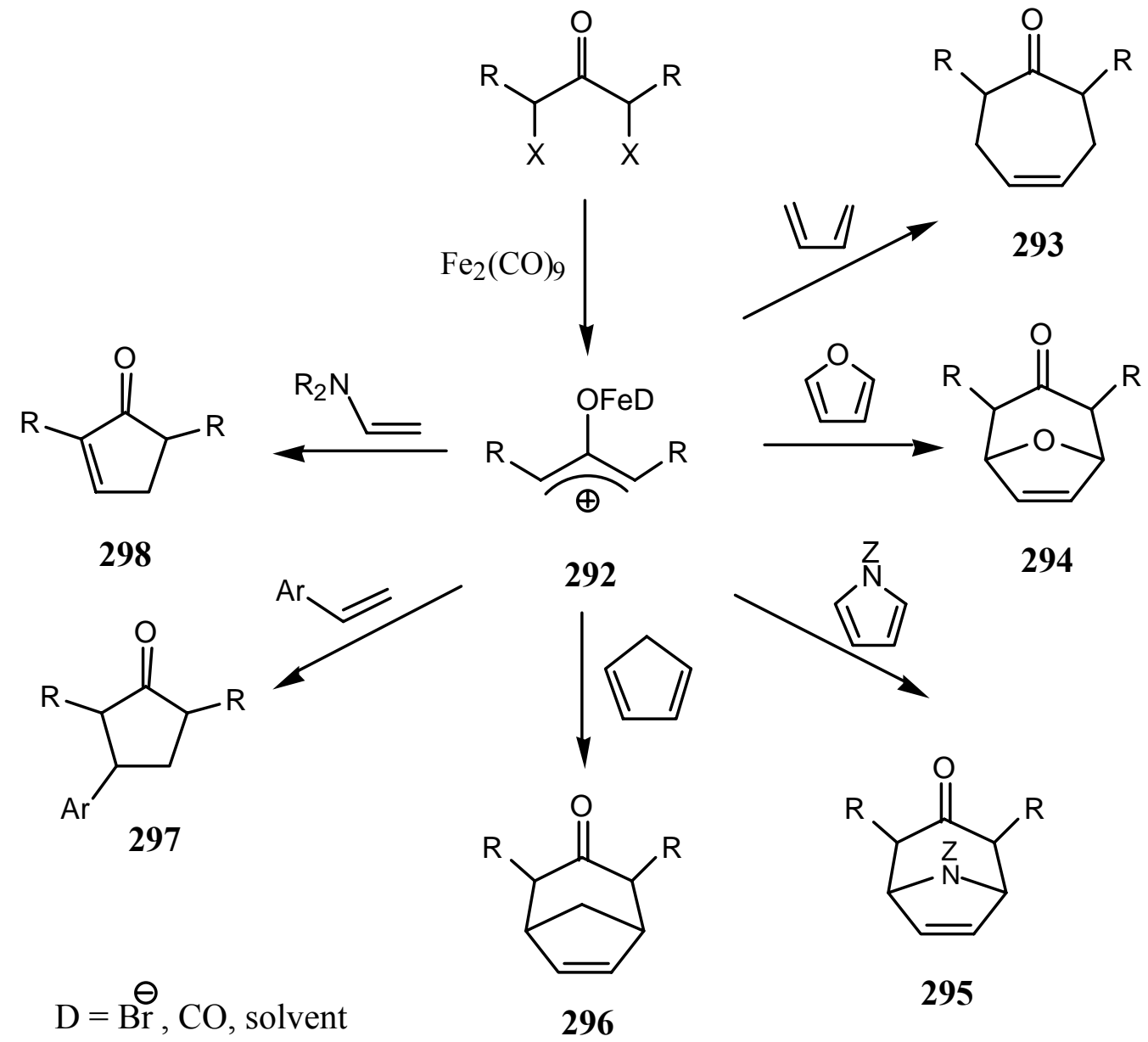

Katritzky and coworkers [545-548] have prepared several pyrrole derivatives $\mathbf{3 0 1}$ by the reaction of alkynyloxirans 300, derived from 1-propargylbenzotriazole (299) with $\alpha$-bromoketones, with primary amines (Scheme 87).

\section{Scheme 87}
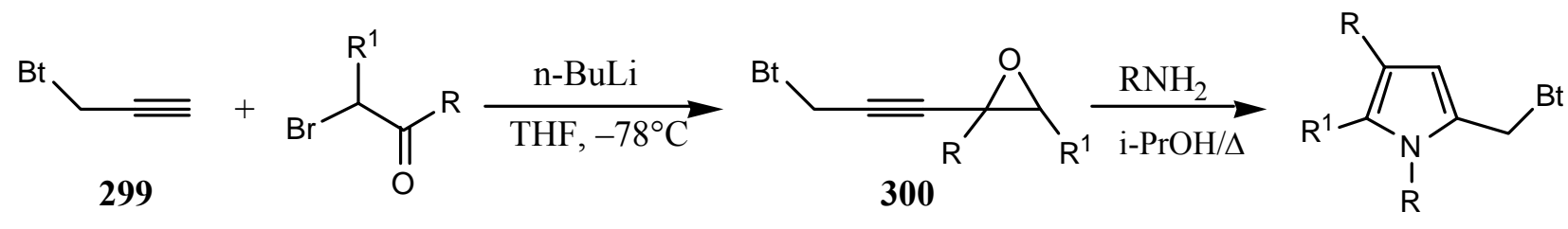

301

$\mathrm{Bt}=$ Benzotriazol-1-yl 


\section{Reactions of $\alpha$-Haloketones with Aldehydes and Ketones}

The condensation of phenacyl halides with aldehydes has been used for the preparation of oxiranes 303. The reaction proceeds via the cross aldol condensation mechanism (Scheme 88) [549-555].

\section{Scheme 88}

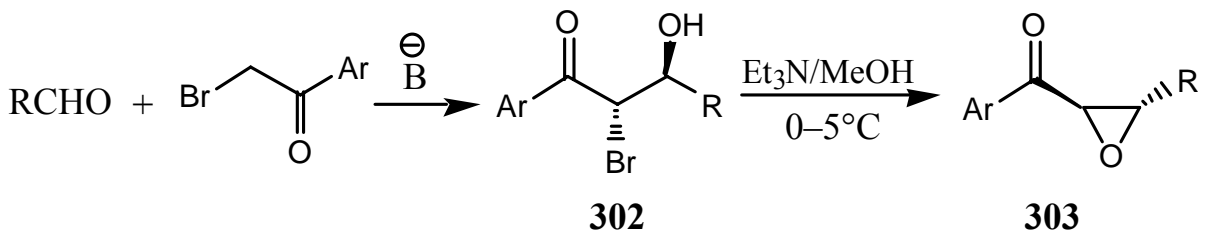

Regiospecific cross aldol-type condensation have been demonstrated by the simultaneous addition of $\alpha$-haloketones and aldehydes or ketones to a mixture of diethylaluminum chloride and zinc [556558], or by means of $\mathrm{Bu}_{3} \mathrm{SnAlEt}_{2}$ complex [559-561], titanium(II) chloride [562], $\mathrm{Co}(0)$ [563], $\mathrm{Sm}$ (II) [564], $\operatorname{In}(0)$ [565], $\mathrm{CrCl}_{2}$ [566] or cobalt(0) trimethylphosphine complex [567,568] to give similar results of the kinetic crossed aldol products $\mathbf{3 0 5}$ (Scheme 89).

\section{Scheme 89}

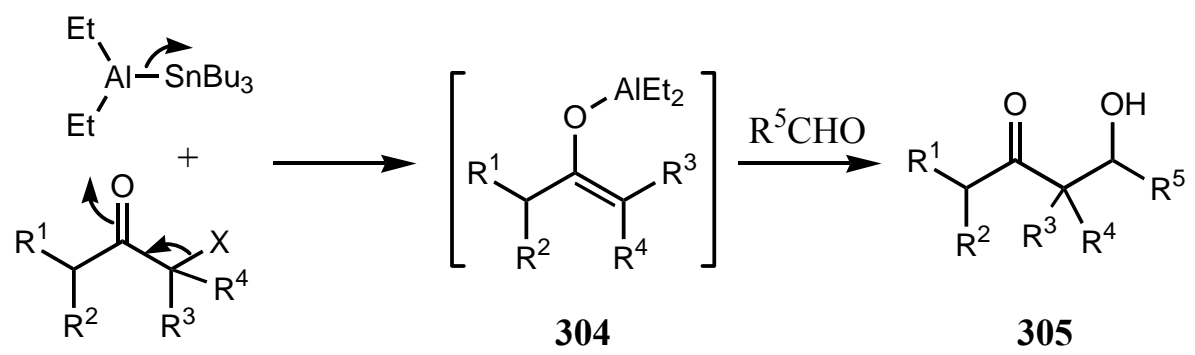

Reaction of $\alpha$-haloketones with aldehydes in the presence of samarium triiodide $\mathrm{SmI}_{3}$ give the corresponding $\alpha, \beta$-unsaturated ketones 306 in good to excellent yields (Scheme 90) [569-573]. Sodium hydrotelluride [574], tin dichloride/sodium sulfite $\left(\mathrm{SnCl}_{2} / \mathrm{Na}_{2} \mathrm{SO}_{3}\right)$ [575] or cerium trichloride [576] furnished similar results.

Scheme 90

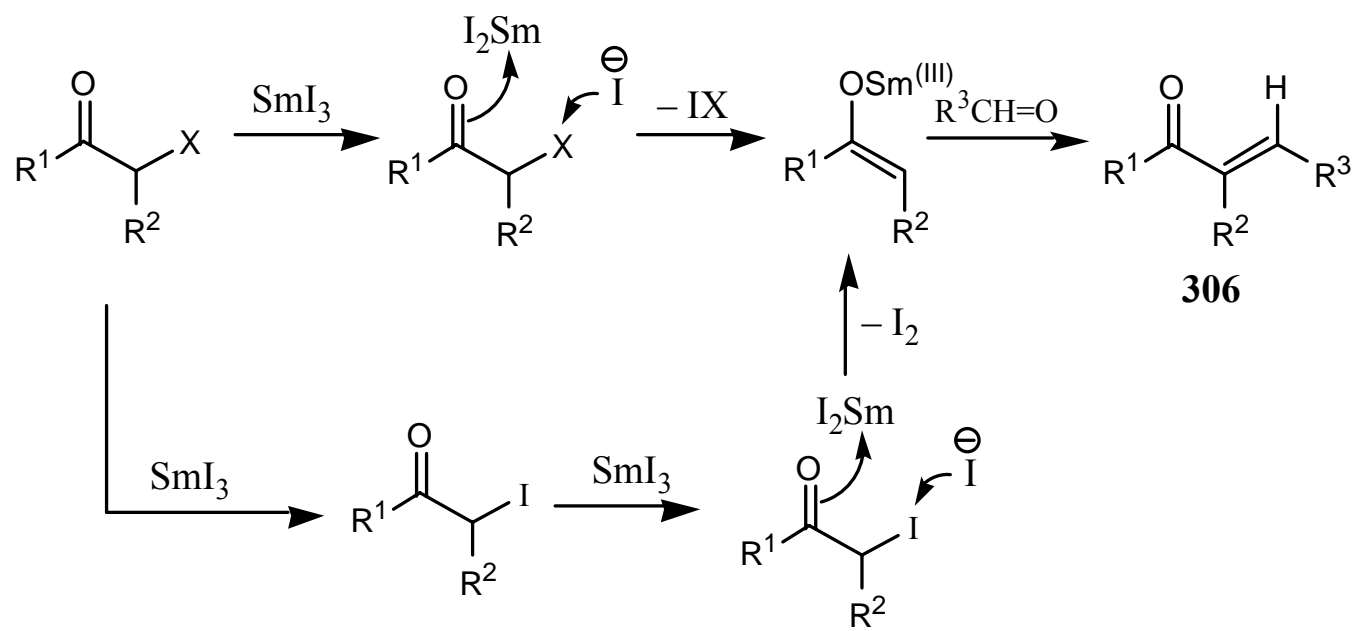


In the presence of diphenylantimonymagnesium, various aldehydes react readily with $\alpha$-bromoacetophenone to yield the corresponding $\alpha, \beta$-unsaturated ketones 310 in good yields (Scheme 91) $[577,578]$.

\section{Scheme 91}

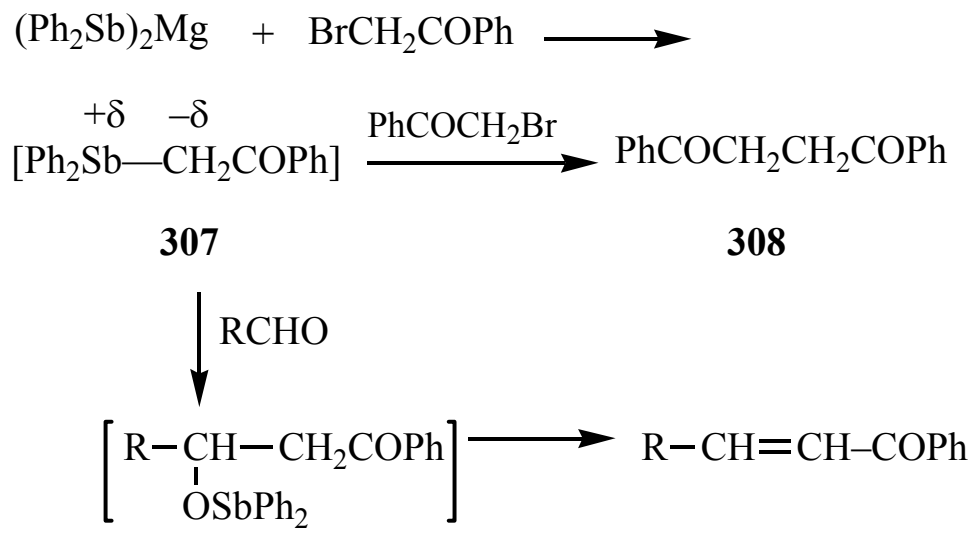

309

310

\section{Miscellaneous Reactions of $\alpha$-Haloketones}

Although some of the following reactions of $\alpha$-haloketones do not give heterocyclic products directly, but it is worthy important to give short notes on such reactions to show up the importance of $\alpha$-haloketones as versatile synthons in the synthetic organic chemistry field.

\section{A. Cyanation and Thiocyanation}

Phenacyl cyanides 311 [579-590] and phenacyl thiocyanates 312 [591-595] have been proven to be valuable tools for the synthesis of a wide variety of heterocyclic compounds. They are simply prepared via the reaction of $\alpha$-haloketones with alkali metal cyanides and thiocyanates, respectively (Eq 7).

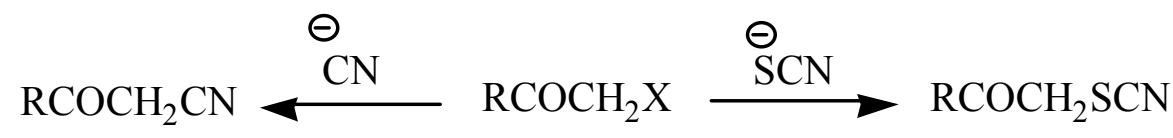

\section{1}

\section{2}

\section{B. Sulfonation}

Reaction of $\alpha$-haloketones with sodium arylsulfinates 313 gave the corresponding 2-(arylsulfonyl)1-substituted-ethanones 314 (Eq 8). The reaction proceeds thermally [596,597] or under phasetransfer catalysis conditions [598,599].

$$
\mathrm{RCOCH}_{2} \mathrm{X}+\mathrm{ArSO}_{2} \mathrm{Na} \longrightarrow \mathrm{RCOCH}_{2} \mathrm{SO}_{2} \mathrm{Ar}+\mathrm{NaX}
$$




\section{Azidation}

It is well-known that reactions of $\alpha$-haloketones with sodium azide under mild conditions produced the corresponding $\alpha$-azido ketones 315 [600-604] which undergo loss of nitrogen giving the corresponding $\alpha$-imino ketones 316 when heated in an inert solvent (Eq 9).

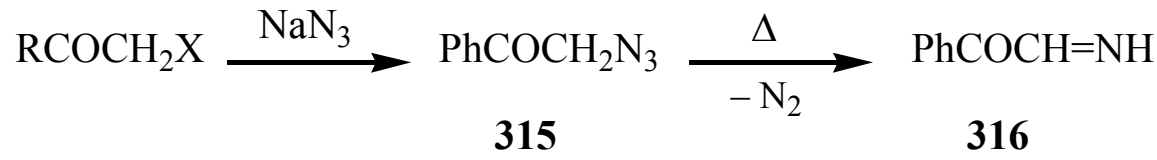

\section{Carboxylation}

The carboxylation of organic halides using palladium catalysts has received little attention because of the severe reaction conditions [605-608]. $\alpha$-Carbomethoxyacetophenone (317) was obtained upon carboxylation of 2-bromoacetophenone with carbon monoxide gas in methanol and in the presence of 1,8-bis(dimethylamino)naphthalene and a catalytic amount of dichlorobis(triphenylphosphine)palladium(II) $\left(\mathrm{PPh}_{3} \mathrm{PdCl}_{2}\right)(\mathrm{Eq} \mathrm{10)}$ [609].

$$
\mathrm{PhCOCH}_{2} \mathrm{Br} \underset{\left(\mathrm{PPh}_{3} \mathrm{PdCl}_{2}\right)}{\stackrel{\mathrm{CO} / \mathrm{MeOH}}{\longrightarrow}} \mathrm{PhCOCH}_{2} \mathrm{CO}_{2} \mathrm{Me}
$$

317

\section{E. Phosphorylation}

Trialkyl phosphites $(\mathrm{RO})_{3} \mathrm{P}$ are known to react with $\alpha$-haloketones to yield $\mathbf{3 1 8}$ (Arbusov reaction) (Eq 11) [610-624].

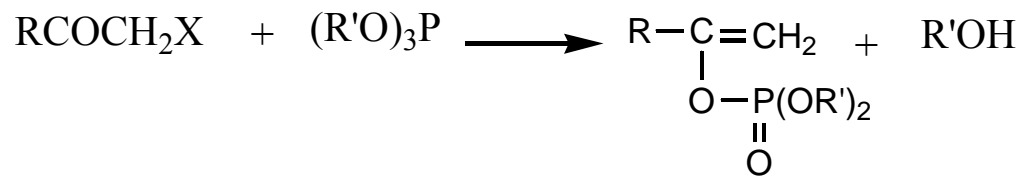

\section{8}

In general, the attack of phosphites can take place at four positions: (1) attack on the carbon atom carrying the halogen giving rise to an enol phosphate $\mathbf{3 1 9}$ or to a $\beta$-ketophosphonate $\mathbf{3 2 0}$; (2) attack on the carbonyl oxygen; (3) attack on the carbonyl carbon, giving rise to an epoxyphosphonate 321 or a vinyl phosphate 319; (4) attack on the halogen, furnishing the enol phosphate 319 (Scheme 92). 


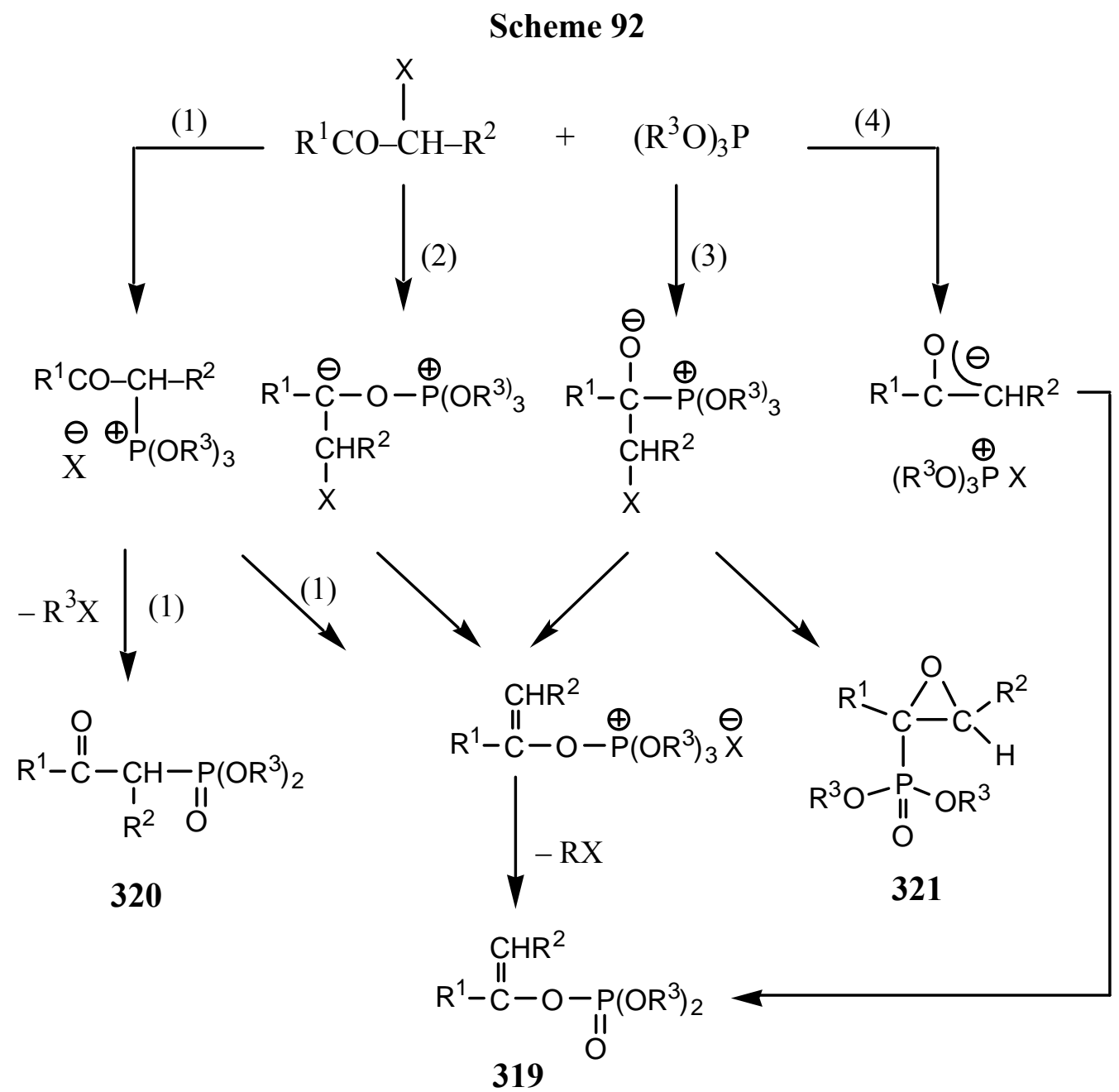

\section{F. Selenation}

The selenation of $\alpha$-haloketones using sodium hydrogen selenide or sodium or magnesium diselenide afforded only the dehalogenated ketones and selenium instead of the corresponding $\alpha$ hydroselenoketones. This is due to the strong reducing power of hydrogen selenide [625]. Selenosubstitution products were obtained when $\alpha$-haloketones reacted with selenonucleophiles [626-636]. For example, a series of selenophenopyridines 323, with antiviral activity, could be prepared via reaction of 3-cyano-2(1H)-pyridineselenones 322 with $\alpha$-haloketones (Scheme 93) [637,638].

Scheme 93<smiles></smiles><smiles>[R]C(=O)c1[se]c2nc([R])cc([R7])c2c1N</smiles> 
Also, imidazo[2,1- $b$ ]selenazoles 325 were prepared by cyclocondensation of 2-aminoselenazoles 324 with $\alpha$-halocarbonyl compounds in ethanol (Scheme 94) [639].

\section{Scheme 94}

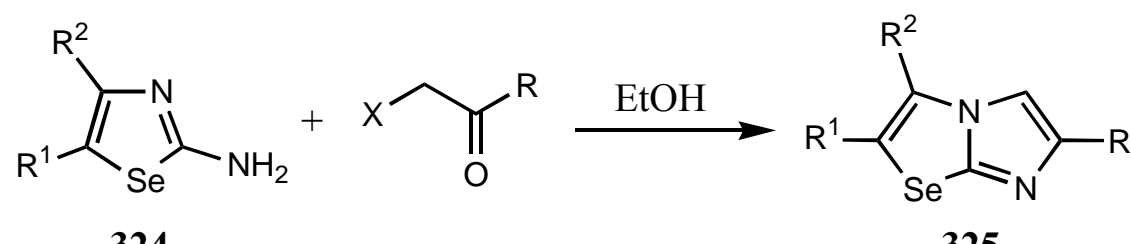

324

325

\section{G. Oximation}

The reaction of $\alpha$-haloketones with hydroxylamine hydrochloride leads to the corresponding $\alpha$ haloketoximes 326 (Scheme 95). Such oximes are good buliding blocks in organic synthesis [640649].

Scheme 95

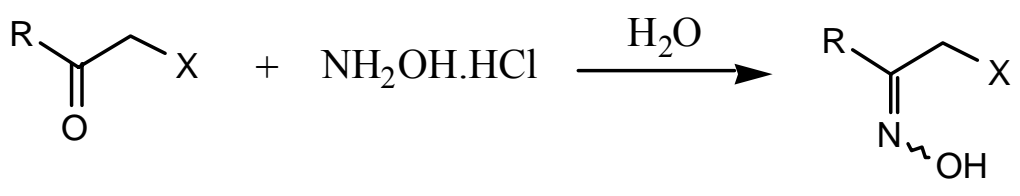

326

On the other hand, the nitrosation of $\alpha$-haloketones with nitrous acid affords $\alpha$-halogenated- $\alpha$ oximinoketones 328 (Scheme 96) [650-652].

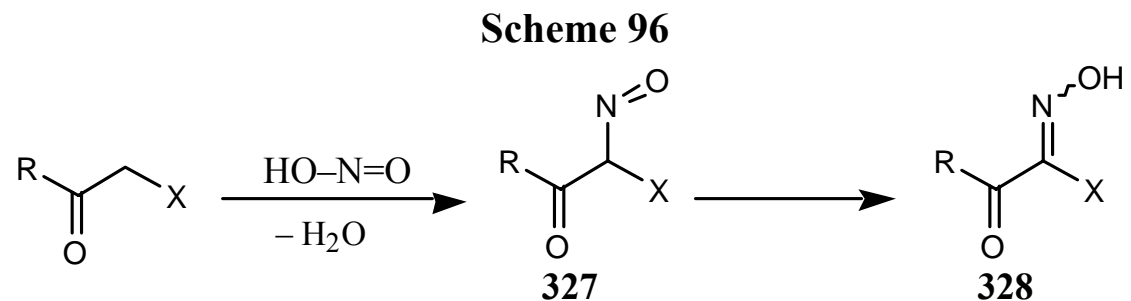

\section{H. Reductive Dehalogenation}

The reductive dehalogenation of $\alpha$-haloketones is an extensively-researched area of organic chemistry [653]. A wide variety of reagents have been employed to carry out this reaction. Among them are aqueous $\mathrm{TiCl}_{3}$ [654], iodide ion [655-659], tellurium reagents [660,661], molybdenum and palladium catalysis [662], nickel boride [663], thiols and selenols [664], metal halides [665-668], sodium dithionite [669], cyanoborohydride [670], inorganic phosphorus compounds [671] and various metal carbonyls [672-676]. Bis(triphenylstannyl)selenide $\left(\mathrm{Ph}_{3} \mathrm{Sn}\right)_{2} \mathrm{Se}$ (329) is one example of reductive reagents, the mechanism of its reductive action on $\alpha$-bromoketones is shown in Scheme 97 [677,678]. 


\section{Scheme 97}
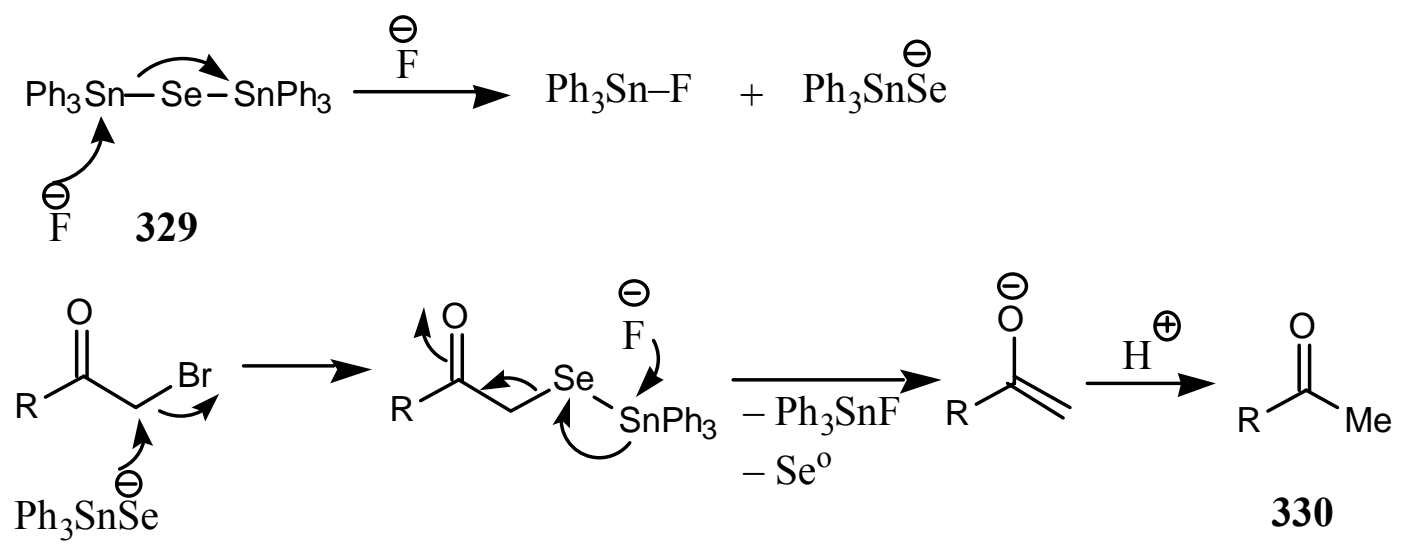

\section{Ketone Reduction}

The asymmetric reduction of $\alpha$-haloketones is potentially a useful process to obtain halohydrins, which are valuable synthetic intermediates for the preparation of a wide range of compounds of biological interests [679-695]. The reaction of $\alpha$-haloketones with sodium borohydride is one of the most popular reduction processes and results in reduction of the carbonyl function with formation of the corresponding halohydrins 331 (Scheme 98) [696-701].

\section{Scheme 98}<smiles>[R]C(=O)C([X])([R])[R]</smiles><smiles>[R]C(O)C([X])([R])[2H]</smiles>

331

\section{K. Photochemistry of $\alpha$-Haloketones}

There are a few reports on the study of the photochemistry of $\alpha$-haloketones involving different types of photoprocesses [702-714]. The photolysis of substituted $\alpha$-chloroacetophenones has been studied in different solvent systems, wherein 1,2-aryl migration is found to be media-controlled [703]. Effect of substituents on the migratory aptitude and a direct access of $\alpha$-chloroacetophenones to acetophenones $\mathbf{3 3 3}$ or aryl acetic acids $\mathbf{3 3 6}$ has been reported by Dhavale et al. (Scheme 99) [703]. 


\section{Scheme 99}<smiles>[R][X]c1ccc(C(=O)CCl)cc1</smiles>

Irradiation of 2,5-dimethyl- $\alpha$-chloroacetophenone (337) in benzene yields 6-methyl-indan-1-one (338) while in methanol, on a mercuric cathode, the photolysis product is 339 (Scheme 100) [715].

\section{Scheme 100}

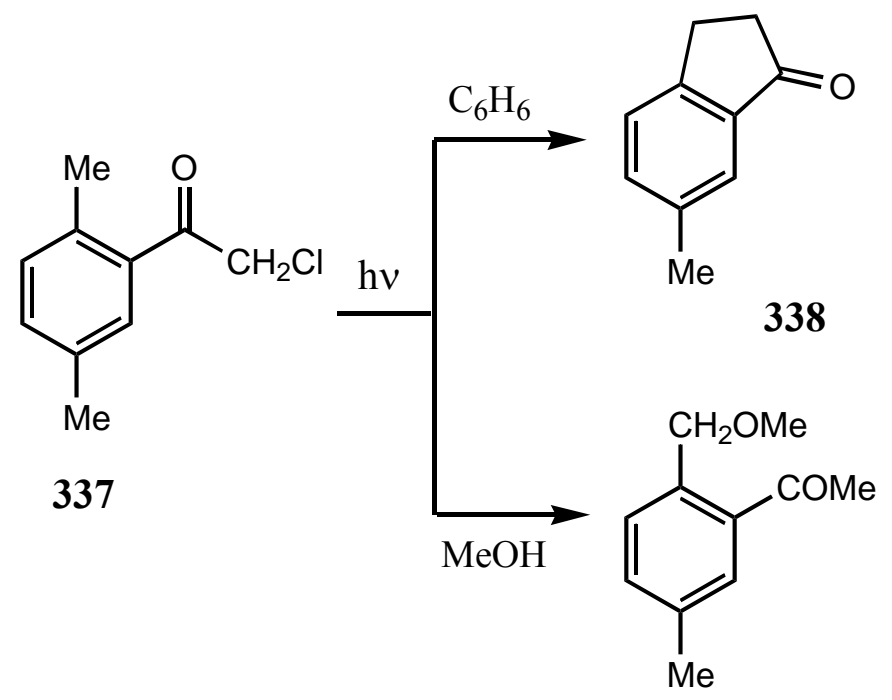

339

\section{Electrochemistry of $\alpha$-Haloketones}

The electrochemical reduction on $\mathrm{Hg}$ cathode of a dropping solution of phenacyl bromides in dry acetone- $\mathrm{LiCrO}_{4}$ yields 4-aryl-2-methylfurans 344 and acetophenones 341 (Scheme 101). In this process, the acetone plays a dual role, as solvent and reagent [716-722]. 


\section{Scheme 101}

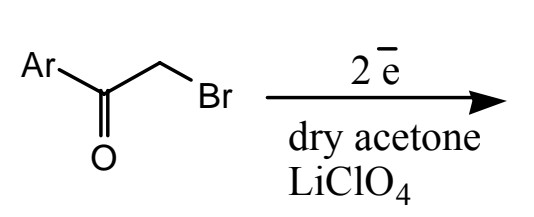

7<smiles></smiles>

340<smiles>CCCCCCCC(C)=O</smiles><smiles>CC(=O)Br</smiles>

341 342

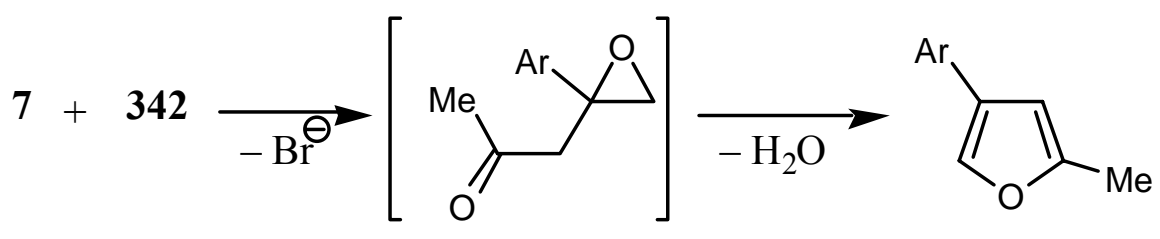

343

The electrochemical reduction of a mixture of aryl halides and $\alpha$-chloroketones in DMF in the presence of $\mathrm{NiBr}_{2}$ leads to the cross-coupling products 345 in good yields (Scheme 102) [723].

Scheme 102

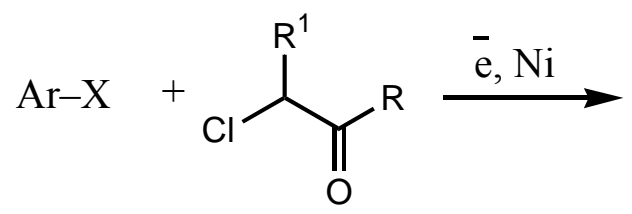<smiles>[R]C(=O)C([R])[Bi]</smiles>

345

\section{Conclusions}

The data considered in this review clearly demonstrate the high synthetic potential of $\alpha$-haloketones. Many biologically active heterocyclic compounds have been obtained based on these reagents $[62,114,122,126,131,458,508,618,626,724-731]$. This suggests that $\alpha$-haloketones can be particularly promising synthons in combinatorial synthesis of functionalized carbo- and heterocyclic compounds used in the design of novel highly effective pharmaceuticals with a broad spectrum of bioresponses. The great interest of chemists in such reagents is confirmed by the facts that more than 500 articles of 731 cited in this review are dated in the last two decades, along with a multitude of patents. 


\section{Acknowledgments}

A. W. Erian is grateful to the Alexander von Humboldt-Stiftung for granting him a research fellowship for finishing this article. He would like to thank Prof. Dr. D. Döpp, Duisburg University, Duisburg, Germany for his very kind hospitality and continuous help. We would like to thank Prof. Dr. T. Fuchigami, Tokyo Institute of Technology, Nagatsuta, Yokohama, Japan and Prof. Dr. Ian W. J. Still, University of Toronto, Mississauga, Ontario, Canada for supplying some of the original references included in this review.

\section{References}

1. Emmerling, E.; Engler, A. Ber. 1871, 4, 148.

2. De Kimpe, N.; Verhé, R. The Chemistry of $\alpha$-Haloketones, $\alpha$-Haloaldehydes and $\alpha$-Haloimines; Patai, S.; Rapporot, Z., Eds.; Interscience: New York, 1988; pp. 1-223.

3. Hahn, W. Methoden der Organischen Chemie; Houben-Weyl, Eds.; George Thieme Verlag, Stuttgart, 1962; pp. 1018-1090.

4. Bayer, O. Methoden der Organischen Chemie; Houben-Weyl, Eds.; Georg Thieme Verlag, Stuttgart, 1977; pp. 2147-2210.

5. Rappe, C. The Chemistry of the Carbon-Halogen Bond; Patai, S., Ed.; Wiley: Chichester, 1973; p. 1071.

6. Jacquier, R., Bull. Soc. Chim. Fr. 1950, 17, 35.

7. Chenier, P. J., J. Chem. Educ. 1978, 55, 286.

8. Kende, A. S. Org. React. 1960, 11, 261.

9. Akhrem, A. A.; Ustynyuk, T. K.; Titov, Y. A. Russ. Chem. Rev. 1970, 39, 732.

10. Tchoubar, B. Bull. Soc. Chim. Fr. 1955, 22, 1363.

11. Mizushima, S.; Shimanouchi, T.; Miyazawa, T.; Ichishima, I.; Kuratani, K.; Nakagawa, I.; Shido, N. J. Chem. Phys. 1953, 21, 815.

12. Laird, R. M.; Whitfield, S. E. J. Chem. Res. (S) 1983, 288.

13. Duek, L. W.; Kagarise, R. E. J. Am. Chem. Soc. 1955, 77, 6156.

14. Bellamy, L. J.; Williams, R. L. J. Chem. Soc. 1957, 4294.

15. Bellamy, L. J.; Thomas, L. C.; Williams, R. L. J. Chem. Soc. 1956, 3704.

16. Jones, R. N.; Spinner, E. Can. J. Chem. 1958, 36, 1020.

17. Subrahmanyam, B.; Venkateshwerlu, G.; Patnaik, D. D.; Reddy, E. P. Proc. Ind. Acad. Sci. (Chem. Sci.) 1980, 89, 219.

18. Dimroth, K.; Reichardt, C.; Siepmann, T.; Bohlmann, F. Liebigs Ann. Chem. 1963, 661, 1.

19. Exner, O. Correlation Analysis in Chemistry, Chapman, N. B.; Shorter, J., Eds.; Plenum: London, 1978; p. 521; p. 531.

20. Schmid, E. D.; Schlenker, P.; Brand, R. R. M. J. Raman Spectrosc. 1977, 6, 314.

21. Katritzky, A. R.; Lagowski, J. M. J. Chem. Soc. 1958, 4155.

22. Katritzky, A. R.; Topsom, R. D. Chem. Rev. 1977, 77, 639. 
23. Nadar, P. A.; Gnanasekaran, C. Ind. J. Chem. 1979, 17B, 391.

24. RamaRao, M.; Bothner-By, A. A. Magn. Reson. 1976, 8, 329.

25. Olivato, P. R.; Guerrero, S. A. J. Chem. Soc., Perkin Trans. 2 1990, 465.

26. Fujiwara, F. Y.; Rittner, R. Org. Magn. Reson. 1984, 22, 199.

27. Duddeck, H.; Feurerhelm, H. T. Tetrahedron 1980, 36, 3009.

28. Stothers, J. B.; Lauterbur, P. C. Can. J. Chem. 1964, 42, 1563.

29. Dahn, H.; Péchy, P. J. Chem. Soc., Perkin Trans. 2 1993, 67.

30. Dahn, H.; Péchy, P.; Toan, V. V. Angew. Chem. 1990, 102, 681.

31. Semin, G. K.; Petukhov, S. A.; Bryukhova, E. V.; Boguslavskii, A. A. Russ. Chem. Bull. 1998, $47,1118$.

32. Smith, J. H.; Heidema, J. H.; Kaiser, E. T.; Wetherington, J. B.; Moncrief, J. W. J. Am. Chem. Soc. 1972, 94, 9274.

33. Wetherington, J. B.; Moncrief, J. W. Acta Crystallog. 1973, 29B, 1520.

34. Erian, A. W. J. Heterocycl. Chem. 2001, 38, 793.

35. Gambaryan, .N. P.; Rokhlin, E. M.; Zeifman, Y. V.; Ching-Yun, C.; Knunyants, I. L. Angew. Chem. 1966, 78, 1008.

36. Chambers, R. D. Fluorine in Organic Chemistry; Wiley: New York, 1973.

37. Hudlicky, M. Chemistry of Organic Fluorine Compounds; Ellis Horwood: Chichester, 1976.

38. Justoni, R. Chim. Ind. 1942, 24, 93.

39. Edwards, E. G.; Evans, D. P.; Watson, H. B. J. Chem. Soc. 1937, 1944.

40. Geiger, M.; Usteri, E.; Gränacher, C. Helv. Chim. Acta 1951, 34, 1340.

41. Bruylants, A.; Houssiau, J. Bull. Soc. Chim. Belg. 1952, 61, 492.

42. Bartlett, P. D.; Rosenwald, R. H. J. Am. Chem. Soc. 1934, 56, 1992.

43. Wanzlick, H. W.; Gollmer, G.; Milz, H. Chem. Ber. 1955, 88, 72.

44. Newman, M. S.; Farbman, M. D.; Hipsher, H. Org. Synth. 1955, 3, 188.

45. Hesse, G.; Urbanek, F. Liebigs Ann. Chem. 1957, 604, 54.

46. Tsuruta, T.; Harada, T.; Nishino, H.; Kurosawa, K. Bull. Chem. Soc. Jpn. 1985, 58, 142.

47. Yonemura, H.; Nishino, H.; Kurosawa, K. Bull. Chem. Soc. Jpn. 1987, 60, 809.

48. Kurkov, V. P. Ger. Offen. 1980, 2,841,490,; [Chem. Abstr. 1980, 93, 71024].

49. Egawa, A.; Miya, T. Jpn. Kokai Tokkyo Koho 1980, 80 02,647; [Chem. Abstr. 1980, 93, 25912].

50. Brintzinger, H.; Orth, H. Monatsh. Chem. 1954, 85, 1015.

51. Rappe, C.; Albrecht, B. Acta Chem. Scand. 1966, 20, 253.

52. Roedig, A.; Maier, R. Chem. Ber. 1953, 86, 1467.

53. Futami, Y.; Nishino, H.; Kurosawa, K. Bull. Chem. Soc. Jpn. 1989, 62, 3567.

54. Vickers, S.; Smissman, E. E. J. Org. Chem. 1975, 40, 749.

55. Shigetaka, Y.; Masao, H.; Takashi, M. Synth. Commun. 1998, 28, 131.

56. Kim, H. J.; Kim, H. R.; Kim, J. N.; Ryu, E. K. Bull. Korean Chem. Soc. 1990, 11, 184.

57. Kim, Y. H.; Lee, I. S.; Lim, S. C. Chem. Lett. 1990, 1125.

58. Villieras, J.; Bacquet, C.; Normant, J. F. J. Organomet. Chem. 1975, 97, 325.

59. Satoh, T.; Mizu, Y.; Kawashima, T.; Yamakawa, K. Tetrahedron 1995, 51, 703. 
60. Lee, J. G.; Park, I. S.; Seo, J. W. Bull. Korean Chem. Soc. 1995, 16, 349.

61. Stevens, C. L.; Beereboom, J. J.; Rutherford, K. G. J. Am. Chem. Soc. 1955, 77, 4590.

62. Kirkov, V. P. Brit. UK Pat. Appl. 1980, 2,028,796; [Chem. Abstr. 1980, 93, 185773].

63. Kröhnke, F.; Timmler, F. Chem. Ber. 1936, 69, 615.

64. Stevens, C. L.; Lenk, C. T. J. Org. Chem. 1954, 19, 538.

65. Newman, M. S. J. Am. Chem. Soc. 1951, 73, 4993.

66. Sawhney, S. N.; Singh, J.; Bansal, O. P. J. Ind. Chem. Soc. 1974, LI, 566.

67. Sket, B.; Zupan, M. Synth. Commun. 1989, 19, 2481.

68. Rahaingoson, F.; Kimpiobi-Ninafiding, B.; Mouloungui, Z.; Gaset, A. Synth. Commun. 1992, 22, 1923.

69. Chekhuta, V. G.; Kucherova, L. A. Metody Poluch. Khim. Reaktiv. Prep. 1970, 22, 40; [Chem. Abstr. 1972, 77, 19307].

70. Adam, W.; Andler, S.; Heil, M. Angew. Chem. 1991, 103, 1395.

71. Traven, V. F.; Smrchek, V. A.; Stepanov, B. I. Zh. Org. Khim. 1973, 9, 576; [Chem. Abstr. 1973, 78, 147013].

72. De Buyck, L.; Verhé, R.; De Kimpe, N.; Courtheyn, D.; Schamp, N. Bull. Soc. Chim. Belg. 1980, 89, 441.

73. Rodygin, M. Y.; Mikhailov, V. A.; Savelova, V. A. Zh. Org. Khim. 1994, 30, 827; [Chem. Abstr. 1995, 122, 187067].

74. Al-Mousawi, S. M.; Bhatti, I.; Saraf, S. D. Org. Prep. Proced. Int. 1992, 24, 60.

75. Cheng, S.; Lin, C.; Liu, L. K. J. Chin. Chem. Soc. (Taipei) 1997, 44, 309.

76. Moughamir, K.; Atmani, A.; Mestdagh, H.; Rolando, C.; Francesch, C. Tetrahedron Lett. 1998, $39,7305$.

77. Kim, K.; Kim, K. Tetrahedron Lett. 1997, 38, 4227.

78. Prostenik, M. V.; Dumic, M.; Bosnjak, N. Monatsh. Chem. 1980, 111, 771.

79. Concellon, J. M.; Bernad, P. L. Tetrahedron Lett. 1998, 39, 7967.

80. Chaudhuri, M. K.; Khan, A. T.; Patel, B. K.; Dey, D.; Kharmawophlang, W.; Lakshmiprabha, T. R.; Mandal, G. C. Tetrahedron Lett. 1998, 39, 8163.

81. Shunmugasundaram, A.; Rajkumar, M. Ind. J. Chem. 1986, 25A, 71.

82. Srinivasan, C.; Shunmugasundaram, A.; Arumugam, N. Ind. J. Chem. 1981, $20 B, 467$.

83. Srinivasan, C.; Shunmugasundaram, A.; Arumugam, N. J. Chem. Soc., Perkin Trans. 2 1985, 17.

84. Baker, J. W. Trans Faraday Soc. 1941, 37, 632.

85. Charton, M. Prog. Phys. Org. Chem. 1981, 13, 119.

86. Mohanty, T. R.; Mishra, M. P.; Nayak, P. L. J. Ind. Chem. Soc. 1974, 51, 799.

87. Ananthakrishnandar, P.; Prabakaran, T. R. Ind. J. Chem. 1996, 35A, 431.

88. Pillay, M.; Kirshna, S. K. Asian J. Chem. 1999, 11, 369.

89. Mishra, S. S.; Behera, G. B.; Nayak, S. Ind. J. Chem. 1985, 24A, 771.

90. Pearson, R. G.; Langer, S. H.; Williams, F. V.; McGuire, W. I. J. Am. Chem. Soc. 1952, 74, 5130. 
91. Nadar, P. A.; Gnanasekaren, C. Bull. Chem. Soc. Jpn. 1979, 52, 2741.

92. Thorpe, J. W.; Warkentin J. Can. J. Chem. 1973, 51, 927.

93. Koo, I. S.; Yang, K.; Park, J. K.; Lee, I. J. Korean Chem. Soc. 1997, 41, 46.

94. Stevens, C. L.; Malik, W.; Pratt, R. J. Am. Chem. Soc. 1950, 72, 4758.

95. Hughes, E. D. Quart. Rev. (London) 1951, 5, 245.

96. Conant, J. B.; Kirner, W. R.; Hussey, R. E. J. Am. Chem. Soc. 1925, 47, 488.

97. Bordwell, F. G.; Brannen, W. T. J. Am. Chem. Soc. 1964, 86, 4645.

98. Sisti, A. J.; Lowell, S. Can. J. Chem. 1964, 42, 1897.

99. Streitweiser, A. Jr. Solvolytic Displacement Reactions; McGraw-Hill: New York, 1962; p. 28.

100. Sabitha, G.; Subba Rao, A. V. Synth. Commun. 1987, 17, 341.

101. Jain, N.; Devin, Krishnamurty, H. G. Ind. J. Chem. 1994, 33B, 1085.

102. Reddy, V. V.; Sampath, R. P.; Ashok, D. Synth. Commun. 2000, 30, 1825.

103. Mahesh, V. K.; Sharma, R. Ind. J. Chem. 1979, 17B, 382.

104. Geetanjali, Y.; Rajitha, B.; Rao, M. K. Bull. Chem. Soc. Jpn. 1986, 59, 1986.

105. Papayan, G. L.; Davtyan, S. M. Khim. Geterosikl. Soedin. 1979, 57; [Chem. Abstr. 1981, 84, 15464].

106. Jorgensen, M.; Krebs, F. C.; Bechgaard, K. J. Org. Chem. 2000, 65, 8783.

107. Minyaeva, L. G.; Golyanskaya, O. M.; Mezheritskii, V. V. Zh. Org. Khim. 1994, 30, 258; [Chem. Abstr. 1995, 122, 160425].

108. Scherrer, R. A. U.S. Pat. 1979, 4,174,403; [Chem. Abstr. 1980, 92, 128895].

109. Arnoldi, A.; Bassoli, A.; Merlini, L.; Ragg, E. J. Chem. Soc., Perkin Trans. 2 1991, 1399.

110. Risitano, F.; Grassi, G.; Foti, F.; Bilardo, C. Tetrahedron Lett. 2001, 42, 3503.

111. Gewald, K.; Jaensch, H. J. J. Prakt. Chem. 1973, 315, 779.

112. Radl, S.; Hezky, P.; Konvicka, P.; Krejci, I. Collect. Czech. Chem. Commun. 2000, 65, 1093.

113. Gewald, K.; Schafer, H.; Bellmann, P. J. Prakt. Chem. 1982, 324, 933.

114. Gewald, K.; Hain, U. Ger. (East) 1975,112,756; [Chem. Abstr. 1976, 84, 164600].

115. Lim, M. J.; Klein, R. S.; Fox, J. J. J. Org. Chem. 1973, 44, 3826.

116. Missbach, M.; Altmann, E.; Widler, L.; Susa, M.; Buchdunger, E.; Missbach, M.; Mett, H.; Meyer, T.; Green, J. Bioorg. Med. Chem. Lett. 2000, 10, 945.

117. El-Bayouki, K. A. M.; Basyouni, W. M.; Hosni, H.; El-Deen, A. S. J. Chem. Res. (S) 1995, 314; (M) 1995, 19901.

118. Bayomi, S. M.; Al-Obaid, R. M.; Jado, A. I.; Loutfy, E. A. Pharmazie, 1989, 44, 814.

119. Abdel-Ghany, H.; El-Sayed, A. M.; El-Shafei, A. K. Synth. Commun. 1995, 25, 1119.

120. Makarova, N. V.; Zemtsova, M. N.; Moiseev, I. K. Khim. Geterotsikl. Soedin. 1994, 621; [Chem. Abstr. 1995, 122, 265303].

121. Carpio, H.; Galeazzi, E.; Greenhouse, R.; Guzman, A.; Velarde, E.; Antonio, Y.; Franco, F.; Leon, A.; Pérez, V.; Salas, R.; Valdés, D.; Ackrell, J.; Cho, D.; Gallergra, P.; Halpern, O.; Koehler, R.; Maddox, M. L.; Muchowski, J. M.; Prince, A.; Tegg, D.; Thurber, T. C.; van Horn, A. R.; Wren, D. Can. J. Chem. 1982, 60, 2296.

122. Kunstmann, R.; Bickel, M. Ger. Offen. DE 1983, 3,205,187; [Chem. Abstr. 1984, 100, 6503]. 
123. Garst, M. E.; Bonfiglio, J. N.; Grudoski, D. A.; Marks, J. J. Org. Chem. 1980, 45, 2307.

124. Hofmann, P.; Sieber, A.; Beck, E.; Schubert, V. Z. Naturforsch. 1983, 38B, 1192.

125. Burns, B.; Coates, B.; Neeson, S.; Stevenson, P. J. Tetrahedron Lett. 1990, 31, 4351.

126. Fujiwara, R.; Nitta, K.; Susumu, I. Japan Kokai 1975, 75 58,059; [Chem. Abstr. 1975, 83, 193076].

127. Zav'yalov, S. I.; Zavozin, A. G.; Dorofeeva, O. V.; Rumyantseva, E. E. Izv. Akad. Nauk. SSSR, Ser. Khim. 1991, 509; [Chem. Abstr. 1991, 115, 8493].

128. Basanagoudar, L. D.; Mahajanshetti, C. S.; Dambal, S. B. Ind. J. Chem. 1991, 30B, 1018.

129. Goerlitzer, K.; Engler, E. Arch. Pharm. (Weinheim) 1980, 313, 405.

130. Jones, C. D.; Suárez, T. J. Org. Chem. 1972, 37, 3622.

131. Walter, L. A. U.S. Pat. 1973, 3,717,644; [Chem. Abstr. 1973, 78, 136092].

132. Sanchez-Yiesca, F.; Gomez, R. Rev. Latioam. Quim. 1984, 14, 106; [Chem. Abstr. 1984, 101, 38297].

133. Vice, S. F.; Frisen, R. W.; Dmitrienko, G. I. Tetrahedron Lett. 1985, 26, 165.

134. Wender, P. A.; White, A. W. Tetrahedron 1983, 39, 3767.

135. Kuroki, M.; Tsunashima, Y. J. Heterocycl. Chem. 1981, 18, 709.

136. Garcia, E. E.; Benjamin, L. E.; Fryer, R. I. J. Heterocycl. Chem. 1973, 10, 51.

137. El-Shafei, A. K.; Soliman, A. M.; Sultan, A. A.; El-Saghier, A. M. M. Gazz. Chim. Ital. 1995, $125,115$.

138. Cocco, M. T.; Congiu, C.; Maccioni, A. J. Heterocycl. Chem. 1990, 27, 683.

139. Cocco, M. T.; Congiu, C.; Maccioni, A., Plumitallo, A.; Schivo, M. L.; De Logu, A. Farmaco 1989, 44, 89.

140. Eguchi, S.; Wakata, Y.; Sasaki, T. J. Chem. Res. (S) 1985, 146.

141. Arrieta, A.; Ganboa, I.; Palomo, C. Synth. Commun. 1984, 14, 939.

142. Buchan, R.; Frases, M.; Kong Thoo Lin, P. V. S. J. Org. Chem. 1985, 50, 1324.

143. Tewari, R. S.; Bajpai, A. J. Chem. Eng. Data 1985, 30, 505.

144. Druta, I. I.; Andrei, M. A.; Ganj, C. I.; Aburel, P. S. Tetrahedron, 1999, 55, 13063.

145. Tewari, R. S.; Dubey, A. K.; Misra, N. K. J. Chem. Eng. Data 1982, 27, 101.

146. Wang, B.; Hu, J.; Zhang, X.; Hu, Y.; Hu, H. J. Heterocycl. Chem. 2000, 37, 1533.

147. Zhou, J.; Hu. Y.; Hu, H. Synthesis 1999, 166.

148. Tsuge, O.; Kanemasa, S.; Takenaka, S. Bull. Chem. Soc. Jpn. 1985, 58, 3320.

149. Tsuge, O.; Kanemasa, S.; Takenaka, S. Bull. Chem. Soc. Jpn. 1985, 58, 3137.

150. Prostakov, N. S.; Baktibaev, O. B. Khim. Geterotsikl. Soedin. 1974, 788; [Chem. Abstr. 1974, 81, 120371].

151. Babaev, E. V.; Pasichnichenko, K. Y.; Pybakov, V. B.; Zhukov, S. G. Chem. Heterocycl. Compd. (N.Y.) 2000, 36, 1192.

152. Caprosu, M.; Ungureanu, M.; Druta, L.; Stavri, N.; Peterovanu, M. Bull. Inst. Politeh. Iasi 1979, 25, 79; [Chem. Abstr. 1980, 92, 198338].

153. Georgescu, F. C.; Georgescu, E. C.; Draghici, C.; Caproiu, T. Rev. Roum. Chim. 1997, 42, 17. 
154. Georgescu, E. I.; Georgescu, F.; Georgescu, M.; Georgescu, E. G.; Petrovanu, M. Rev. Roum. Chim. 1985, 30, 611.

155. McHatti, D.; Buchan, R.; Fraser, M; Lin, P. V. S. K. Heterocycles 1992, 34, 1759.

156. Minguez, J. M.; Castellote, M. I.; Vaquero, J. V.; Garcia-Navio, J. L. J. Org. Chem. 1996, 61, 4655.

157. De Pablo, M. S.; Gandásequi, T.; Vaquero, J. J.; Navio, J. L. G.; Alvarez-Builla, J. A. Tetrahedron 1992, 48, 8793.

158. Kochergin, P. M.; Mashkovskii, M. D.; Druzhinina, A. A.; Kaminka, M. E. Khim-Farm. Zh. 1976, 10, 59; [Chem. Abstr. 1976, 85, 62993].

159. Zugravescu, I.; Herdan, I.; Druta, I. Rev. Roum. Chim. 1974, 19, 649.

160. Jones, R. C. F.; Nichols, J. R.; Cox, M. T. Tetrahedron Lett. 1990, 31, 2333.

161. Kim, D. J.; Yoo, K. H.; Park, S. W. J. Org. Chem. 1992, 57, 2347.

162. Potts, K. T.; Choudhury, D. R.; Westby, T. R. J. Org. Chem. 1976, 41, 187.

163. Untch, K. G.; Gardner, J. O. U.S. Pat. 1975, 3,920,672; [Chem. Abstr. 1976, 84, 121807].

164. Surpateanu, G. G.; Vergoten, G.; Elass, A.; Surpateanu, G. Heterocycles 1999, 51, 2213.

165. Petrovanu, M.; Luchian, C.; Surpateanu, G.; Barboiu, V. Rev. Roum. Chim. 1979, 24, 733.

166. Kovtunenko, V. A.; Babichev, F. S. Ukr. Khim. Zh. 1972, 38, 1142; [Chem. Abstr. 1973, 78, 58327].

167. Surpateanu, G.; Catteau, J. P.; Karafiloglou, P.; Lablache-Combier, A. Tetrahedron 1976, 32 , 2647.

168. Dietrich, M.; Bode, D. O. J. Chem. Soc., Perkin Trans. 1 1992, 1483.

169. Anitha, I.; Rajan, P. K. J. Ind. Chem. Soc. 1989, 66, 460.

170. Noguchi, M.; Tanigawa, N.; Kajigaeshi, S. J. Heterocycl. Chem. 1985, 22, 1049.

171. Sliwa, H.; Blondeau, D.; Rydzkowski, R. J. Heterocycl. Chem. 1983, 20, 1613.

172. Goehring, R. R. Tetrahedron Lett. 1992, 33, 6045.

173. Yokoyama, M.; Imamoto, T. Synthesis 1984, 797 and references cited therein.

174. Gompper, R.; Kutter, E. Angew. Chem. 1962, 251.

175. Jensen, K. A.; Henriksen, L. Acta Chem. Scand. 1968, 22, 4.

176. Ronsisvalle, G. Farmaco, Ed. Sci. 1980, 35, 341; [Chem. Abstr. 1980, 93, 71432].

177. Schaefer, H.; Gewald, K. J. Prakt. Chem. 1975, 317, 337.

178. Briel, D. Pharmazie 1990, 45, 895.

179. Sherif, S. M.; Abdel-Sayed, N. I.; El-Kousy, S. M.; Mohareb, R. M. Monatsh. Chem. 1995, 126, 601.

180. Mohareb, R. M.; Sherif, S. M. J. Chem. Res. (S) 1994, 484.

181. Mohareb, R. M.; Sherif, S. M.; Habashi, A.; Abdel-Sayed, N. I.; Osman, S. S. Collect. Czech. Chem. Commun. 1995, 60, 1578.

182. Miyahara, Y. J. Heterocycl. Chem. 1979, 16, 1147.

183. Asinger, F.; Schäfer, W.; Baumann, M.; Römgens, H. Liebigs Ann. Chem. 1964, 672, 103.

184. Geisler, G.; Stache, F. Chem. Ber. 1961, 94, 337.

185. Gierer, J.; Alfredson, B. Chem. Ber. 1957, 90, 1240. 
186. Cagniant, P.; Kirsch, G. C. R. Hebd. Seances Acad. Sci. 1975, 281C, 35; [Chem. Abstr. 1975, 83, $178681]$.

187. Turnbull. M. D.; Bansal, H. S.; Smith, A. M.; Salmon, R.; Fitzjohn, S.; Godrey, C. R. A.; Hotson, M. B.; Sillars, N. C.; Dowling, A. J. PCT Int. Appl. WO 1995, 95 24,403; [Chem. Abstr. 1996, 124, 117350].

188. Gewald, K.; Hain, U. Monatsh. Chem. 1992, 123, 455.

189. Sharma, S. Sulfur Rep. 1989, 8, 327.

190. Schaefer, H.; Gewald, K. Z. Chem. 1975, 15, 100.

191. Shestopalov, A. M.; Litvinov, V. P.; Sharanin, Yu. A.; Demerkov, A. S.; Nesterov, V. N. Izv. Akad. Nauk. SSSR, Ser. Khim. 1991, 1637; [Chem. Abstr. 1991, 115, 207905].

192. Suma, S.; Ushakumari, N. K.; Asokan, C. V. Phosphorus, Sulfur Silicon Relat. Elem. 1997, 131, 161.

193. Mohareb, R. M. Gazz. Chim. Ital. 1992, 122, 147.

194. Mohareb, R. M.; Aziz, S. I.; Abdel-Sayed, N. I.; Shams, H. Z. J. Chin. Chem. Soc. 1992, 39, 181.

195. Mohareb, R. M.; Shams, H. Z.; Aziz, S. I. J. Chem. Res. (S) 1992, 154.

196. Mohareb, R. M.; Zohdi, H. F.; Sherif, S. M.; Wardakhan, W. W. Tetrahedron 1994, 50, 5807.

197. Abdelhamid, A. O.; Al-Shehri, S. M. J. Chem. Res. (S) 1997, 240.

198. Abdelhamid, A. O.; Zohdi, H. F.; Mohamed, G. S. Heteroat. Chem. 1999, 10, 508.

199. Markert, J.; Hagen, H. Liebigs Ann. Chem. 1980, 768.

200. Yazawa, N.; saito, Y.; Hiyoshi, H.; Yoshide, Y. PCT Int. Appl. WO 1995, 95 09,165; [Chem. Abstr. 1995, 123, 55688].

201. Huang, Q.; Lun, M.; Chen, D.; Ji, J. Youji Huaxue 1995, 15, 245.

202. Litvinov, V. P.; Rodinovskaya, L. A.; Sharanin, Y. A.; Shestopalov, A. M. Sulfur Rep. 1992, 13, 1.

203. Becher, J.; Stidsen, C. E. Sulfur Rep. 1988, 8, 105.

204. Kislyi, V. P.; Nikishin, K. G.; Kruglova, E. Y. Tetrahedron 1996, 52, 10841.

205. Gewald, K.; Hentschel, M.; Illgen, U. J. Prakt. Chem. 1974, 316, 1030.

206. Tornetta, B.; Guerrera, F.; Ronsisvalle, G. Ann. Chim. (Rome) 1974, 64, 833.

207. Guerrera, F.; Siracusa, M. A.; Tornetta, B. Farmaco, Ed. Sci. 1976, 31, 21.

208. Elgemeie, G. E. H.; Elfahham, H. A.; Nabby, H. A. Sulfur Lett. 1989, 9, 47.

209. Elnagdi, M. H.; Ghozlan, S. A. S.; Abdelrazek, F. M.; Maghraby, A. S. J. Chem. Res. (S) 1991, 116.

210. Elnagdi, M. H.; Erian, A. W. Bull. Soc. Chim. Fr. 1995, 132, 920.

211. Matrosova, S. V.; Zav'yalova, V. K.; Litvinov, V. P.; Sharanin, Y. A. Izv. Akad. Nauk. SSSR, Ser. Khim. 1991, 1643; [Chem. Abstr. 1991, 115, 207882].

212. Briel, D.; Dumke, S.; Olk, B. J. Chem. Res. (S) 1992, 144; (M) 1062.

213. Elgemeie, G. E. H.; El-Zanate, A. M.; Mansour, A. E. Bull. Chem. Soc. Jpn. 1993, 66, 555.

214. Deep, A.; Essawy, A.; El-gendy, A. M.; Shaban, A. M. Egypt. J. Chem. 1990, 33, 215.

215. Elgemeie, G. E. H.; Alnaimi, I. S.; Alarab, H. F. Heterocycles 1992, 34, 1721. 
216. Litvinov, V. P.; Sharanin, Y. A.; Rodinovskaya, L. A.; Nesterov, V. N.; Shklover, V. E.; Struchkov, Y. T. Chem. Scr. 1989, 29, 327.

217. Artemov, V. A.; Shestopalov, A. M.; Litvinov, V. P. Khim. Geterotsikl. Soedin. 1996, 512; [Chem. Abstr. 1996, 125, 167829].

218. Hafez, A. A. A.; El-Dean, A. K.; Hassan, A. A.; El-Kashef, H. S.; Rault, S.; Robba, M. J. Heterocycl. Chem. 1996, 33, 431.

219. Frolova, N. G.; Zav'yalova, V. K.; Litvinov, V. P. Izv. Akad. Nauk, Ser. Khim. 1996, 2719; [Chem. Abstr. 1997, 126, 131360].

220. Sharanin, Y. A.; Matrosova, S. V. Zh. Org. Khim. 1996, 32, 1251.

221. Attaby, F. A.; Abdel-Fattah, A. M. Phosphorus, Sulfur Silicon Relat. Elem. 1996, 119, 257.

222. Attaby, F. A.; Eldin, S. M.; Bassyouni, W. M.; Elneairy, M. A. A. Phosphorus, Sulfur Silicon Relat. Elem. 1996, 119, 1.

223. Attaby, F. A.; Eldin, S. M.; Abou-Abdou, M. B. Phosphorus, Sulfur Silicon Relat. Elem. 1997, $129,121$.

224. Krivokolysko, S. G.; Dyachenko, V. D.; Litvinov, V. P. Russ. J. Org. Chem. 1997, 33, 1018.

225. Geies, A. A.; El-Dean, A. M. K. Bull. Pol. Acad. Sci. Chem. 1997, 45, 381.

226. Abu-Shanab, F. A. J. Chem. Res. (S) 1999, 430.

227. Dyachenko, V. D.; Litvinov, V. P. Russ. J. Org. Chem. 1998, 34, 696.

228. Bakhite, E. A. J. Chem. Res. (S) 2000, 500; (M) 1201.

229. Rodinovskaya, L. A.; Shestopalov, A. M. Russ. Chem. Bull. 2000, 49, 348.

230. Erian, A. W.; Konno, A.; Fuchigami, T. Tetrahedron Lett. 1994, 35, 7245.

231. Erian, A. W.; Konno, A.; Fuchigami, T. J. Org. Chem. 1995, 60, 7664.

232. Erian, A. W.; Abu-Shanab, F. A. Bull. Chem. Soc. Jpn. 1998, 71, 2387.

233. Dawood, K. M.; Fuchigami, T. J. Org. Chem. 1999, 64, 139.

234. Higashiya, S.; Sato, T.; Fuchigami, T. J. Fluorine Chem. 1998, 87, 203.

235. Tornetta, B.; Ronsisvalle, G.; Bousquest, N.; Guerera, F.; Siracusa, M. A. Gazz. Chim. Ital. 1980, 110, 233.

236. Kalcheva, V.; Tosheva, M.; Izv. Khim. 1991, 24, 394; [Chem. Abstr. 1993, 118, 191595$].$

237. Ozturk, T. Tetrahedron Lett. 1996, 37, 2821.

238. Dannhardt, G.; Grobe, A.; Obergrusberger, R. Arch. Pharm. (Weinheim) 1987, 320, 582.

239. Little, T. L.; Webber, S. E. J. Org. Chem. 1994, 59, 7299.

240. Greenhalgh, R.; Bannard, R. A. B. Can. J. Chem. 1961, 39, 1017.

241. Matsumoto, K.; Rapoport, H. J. Org. Chem. 1968, 33, 552.

242. Khanna, I. K.; Weier, R. M.; Collins, P. W.; Yu, Y.; Xu, X.; Huff, R. M.; Partis, R. A.; Koszyk, F. J. PCT Int. Appl. WO 1996, 96 03,388; [Chem. Abstr. 1996, 125, 33646].

243. Cocco, M. T.; Olla, C.; Onnis, V.; Schivo, M. L.; De Logu, A. Farmaco 1992, 47, 229.

244. Grafe, A.; Liebig, H.; Pfetzing, H. Ger. Offen. 1973, 2,149,245; [Chem. Abstr. 1973, 78, 159603].

245. Wegner, K.; Schunack, W. Arch. Pharm. (Weinheim) 1974, 307, 972.

246. Galewicz, K. Acta Pol. Pharm. 1991, 48, 43. 
247. Zav'yalov, S. I.; Ezhova, G. I.; Sitkareva, I. V. Izv. Akad. Nauk SSSR, Ser. Khim. 1991, 511; [Chem. Abstr. 1991, 115, 8669].

248. Iradyan, M. A.; Torosyan, A. G.; Aroyan, A. A. Arm. Khim. Zh. 1974, 27, 337; [Chem. Abstr. 1974, 81, 91428].

249. Hori, M.; Tanaka, K.; Kataoka, T.; Shimizu, H.; Imai, E.; Kimura, K.; Hashimoto, Y. J. Chem. Soc., Perkin Trans. 1 1985, 2333.

250. Crank, G.; Khan, H. R. Aust. J. Chem. 1985, 38, 447.

251. Zav'yalov, S. I.; Sitkareva, I. V.; Ezhova, G. I.; Dorofeeva, O. V.; Zavozin, A. G.; Rumyantseva, E. E. Izv. Akad. Nauk. SSSR, Ser. Khim. 1990, 1435; [Chem. Abstr. 1990, 113, 191234].

252. Zav'yalov, S. I.; Sitkareva, I. V.; Ezhova, G. I.; Dorofeeva, O. V.; Zavozin, A. G. Khim. Geterotsikl. Soedin. 1990, 847; [Chem. Abstr. 1991, 114, 23873].

253. Barnett, M.; Secondo, P.; Collier, H. J. Heterocycl. Chem. 1996, 33, 1363.

254. Sato, T.; Matsuoka, M. Jpn. Kokai Tokkyo Koho JP 1995, 07,278,455; [Chem. Abstr. 1996, 124, 90281].

255. Seneci, P.; Nicola, M.; Inglesi, M.; Vanotti, E.; Resnati, G. Synth. Commun. 1999, $29,311$.

256. Abe, N.; Nishiwaki, T.; Yamamoto, H.; Kunishige, N. Bull. Chem. Soc. Jpn. 1983, 56, 3703.

257. Koshchienko, Y. V.; Suvorova, G. M.; Simonov, A. M. Khim. Geterosikl. Soedin. 1975, 140; [Chem. Abstr. 1975, 82, 140013].

258. Bender, P. E. U.S. Pat. 1980, 4,186,205; [Chem. Abstr. 1980, 92, 181195].

259. Ishida, N.; Imafuku, K. J. Heterocycl. Chem. 1992, 29, 1219.

260. Mekonnen, B.; Crank, G.; Craig, D. J. Heterocycl. Chem. 1997, 34, 589.

261. Singh, J. V. J. Ind. Chem. Soc. 1974, 51, 559.

262. Kano, S.; Taniguchi, T. Japan Kokai 1973, 73 19,592; [Chem. Abstr. 1973, 78, 147964].

263. Fajgelj, S.; Stanovnik, B.; Tisler, M. Heterocycles 1986, 24, 379.

264. Andreani, A.; Rambaldi, M.; Bonazzi, D.; Bossa, R.; Galatulas, I. Arch. Pharm. (Weinheim) 1985, 318, 1003.

265. Demchenko, A. M.; Chumakov, V. A.; Krasovskii, A. N.; Pirozhenko, V. V.; Lozinskii, M. O. Chem. Heterocycl. Compd. (N. Y.) 1997, 33, 728.

266. Demchenko, A. M.; Chumakov, V. A.; Krasovskii, A. N.; Pirozhenko, V. V.; Lozinskii, M. O. Chem. Heterocycl. Compd. (N.Y.) 1997, 33, 724.

267. Pentimalli, L.; Milani, G.; Biavati, F. Gazz. Chim. Ital. 1977, 107, 1.

268. Joshi, K. C.; Pathak, V. N.; Panwar, M. P. J. Ind. Chem. Soc. 1979, 56, 716.

269. Mohan, J.; Anjaneyulu, G. S. R. Ind. J. Chem. 1989, 28B, 500.

270. Pentimalli, L.; Milani, G.; Franco, B. Gazz. Chim. Ital. 1975, 105, 777.

271. Sitte, A.; Wassel, R.; Paul, H. Monatsh. Chem. 1975, 106, 1291.

272. Srivastava, S. K.; Pathak, R. B.; Bahel, S. Ind. J. Chem. 1991, 30B, 620.

273. Claramunt, R. M.; Granados, R.; Pedroso, E. Bull. Soc. Chim. Fr. 1973, 1854.

274. Moderhack, D.; Bode, D. O.; Schomburg, D. Chem. Ber. 1993, 126, 129.

275. Tomoda, H.; Hirano, T.; Saito, S.; Mutai, T.; Araki, K. Bull. Chem. Soc. Jpn. 1999, 72, 1327.

276. Hand, E. S.; Paudler, W. W. J. Org. Chem. 1980, 45, 3738. 
277. Sharma, A.; Behera, G. B. Ind. J. Chem. 1976, 14B, 551.

278. Möhrle, H.; Schillings, P. Arch. Pharm. (Weinheim) 1986, 319, 659.

279. Matschay, A.; Skwarski, D.; Sobiak, S. Pol. J. Chem. 2000, 74, 1707.

280. Möhrle, H.; Grimm, B. Arch. Pharm. (Weinheim) 1986, 319, 325.

281. Ito, S.; Kakehi, A.; Miwa, T. Heterocycles 1991, 32, 2373.

282. Gueiffier, A.; Blache, Y.; Viols, H.; Chapat, J. P.; Chavignon, O.; Teulade, J. C.; Dauphin, G.; Debouzy, J. C.; Chabard, J. L. J. Heterocycl. Chem. 1992, 29, 283.

283. Rogul'chenko, G. K.; Mazur, I. A.; Kochergin, P. M. Farm. Zh. (Kiev) 1976, 29; [Chem. Abstr. 1976, 85, 192657].

284. Ogawa, K.; Masahiro, N.; Inagaki, J.; Nohara, F.; Saito, T.; Itaya, T.; Fujii, T. Chem. Pharm. Bull. 1992, 40, 343.

285. Laneri, S.; Sacchi, A.; Abignente, E. J. Heterocycl. Chem. 2000, 37, 1265.

286. Kalinowska-Torz, J. Acta Pol. Pharm. 1985, 42, 112.

287. Anisimova, V. A.; Pozharskii, A. F.; Simonov, A. M.; Dal'-nikovskaya, V. V. Khim. Geterotsikl. Soedin. 1974, 1578; [Chem. Abstr. 1975, 82, 57637].

288. Senga, K.; Robins, R. K.; O'Brien, D. E. J. Heterocycl. Chem. 1975, 12, 1043.

289. Rao, K. V. P.; Reddy, P. S. N.; Sundaramurthy, V. Ind. J. Chem. 1985, 24B, 1120.

290. Hantzsch, A.; Weber, J. H. Ber. Dsch. Chem. Ges. 1887, 20, 3118.

291. Traumann, V. Justus Liebigs Ann. Chem. 1888, 249, 31.

292. Vernin, G. Thiazole and its Derivatives, Metzger, J. V. Ed.; J. Wiley and Sons, New York, 1979; Part 1, Chapter 2,.

293. De Kimpe, N.; Declercq, J. Tetrahedron 1993, 49, 3411.

294. Sarkis, G. Y.; Al-Azawe, S. J. Chem. Eng. Data 1973, 18, 99.

295. Dash, B. C.; Nandi, B. B. J. Ind. Chem. Soc. 1979, LVI, 70.

296. Singh, H.; Ahuja, A. S. Ind. J. Chem. 1979, 18B, 534.

297. Liebscher, J.; Pätzel, M.; Bechstein, U. Synthesis 1989, 968.

298. Mohareb, R. M.; Shams, H. Z.; Aziz, S. I. Sulfur Lett. 1991, 13, 101.

299. Khazi, I. M.; Mahajanshetti, C. S. Monatsh. Chem. 1995, 126, 759.

300. Kidwai, M.; Kumar, R. Gazz. Chim. Ital. 1997, 127, 263.

301. Kasmi, S.; Hamelin, J.; Benhaoua, H. Tetrahedron Lett. 1998, 39, 8093.

302. Binu, R.; Thomas, K. K.; Jenar-Danan, G. C.; Rajasekharan, K. N. Org. Prep. Proced. Int. 1998, 30, 93.

303. Demirayak, S.; Karaburun, A. C.; Mohsen, U. A.; Guven, K. Acta Pharm. Turc. 1999, 41, 78.

304. Rudolph, J. Tetrahedron 2000, 56, 3161.

305. Suni, M. M.; Nair, V. A.; Joshua, C. P. Synlett 2001, 409.

306. Behera, G. B.; Acharya, R. C.; Rout, M. K. Ind. J. Chem. 1973, 11, 82.

307. Schäfer, V. H.; Gewald, K. J. Prakt. Chem. 1974, 316, 684.

308. Meslin, J. C.; Quiniou, H. Tetrahedron 1975, 31, 3055.

309. Rajappa, S. Heterocycles 1977, 7, 507. 
310. Lin, Y.; Seifert, C. M.; Kang, S. M.; Dusza, J. P.; Lang, S. A. J. Heterocycl. Chem. 1979, 16, 1377.

311. Reliquet, A.; Meslin, J.; Reliquet, F. Sulfur Lett. 1978, 7, 49.

312. Harode, R.; Sharma, T. C. J. Ind. Chem. Soc. 1989, 66, 282.

313. Rober, P.; Gully, D.; Courtemanche, G.; Gautier, C.; Geslin, M.; Wermurth, C. Eur. Pat. Appl. EP 1995, 659,747; [Chem. Abstr. 1995, 123, 143883].

314. Farag, A. M.; Dawood, K. M.; Kandeel, Z. E.; Algharib, M. S. J. Chem. Res. (S) 1996, 530.

315. Feng, Y.; Zhang, X.; Zhang, W. Hecheng Huaxue 1997, 5, 269; [Chem. Abstr. 1998, 128, 243992].

316. Amschler, H.; Martin, T.; Flockerzi, D.; Gutterer, B.; Thibaut, U.; Hatzelmann, A.; Boss, H.; Hafner, D.; Kley, H.; Beume, R.; Bar, T.; Ulrich, W. PCT Int. Appl. WO 1998, 98 08,830; [Chem. Abstr. 1998, 128, 204882].

317. Kalluraya, B.; Gunaga, P.; Ramana, M. V. Ind. J. Heterocycl. Chem. 1999, 8, 241.

318. Dovlatyan, V. V.; Eliazyan, K. A.; Pivazyan, V. A.; Ghazaryan, E. A.; Engoyan, A. P.; Grigoryan, R. T.; Mirzoyan, R. G. Chem. Heterocycl. Compd. (N.Y.) 2000, 36, 593.

319. Brown, M. D.; Gillon, D. W.; Meakins, G. D.; Whitham, G. A. J. Chem. Soc., Chem. Commun. 1982, 444.

320. Fuchigami, T.; Yeh, M. Y.; Nonaka, T.; Tien, H. J. Bull. Chem. Soc. Jpn. 1983, 56, 3851.

321. Fuchigami, T.; Nonaka, T. J. Org. Chem. 1983, 48, 3340.

322. Sandstrom, J. Arkiv Kemi 1954, 7, 249.

323. Sandstrom, J. Arkiv. Kemi 1956, 9, 127.

324. Katritzky, A. R.; Bayyuk, S. Heterocycles 1985, 23, 3099.

325. Zohdi, H. F.; Wardakhan, W. W.; Doss, S. H.; Mohareb, R. M. J. Chem. Res. (S) 1996, 440; (M) 2526.

326. Mohareb, R. M.; Zohdi, H. F.; Wardakhan, W. W. Monatsh. Chem. 1995, 126, 1391.

327. Zohdi, H. F. J. Chem. Res. (S) 1998, 536.

328. Mohareb, R. M.; Sherif, S. M. Heteroat. Chem. 1997, 8, 77.

329. Guerin, D.; Carlier, R.; Lorcy, D. J. Org. Chem. 2000, 65, 6069.

330. Sedavkina, V. A.; Bespalova, G. V.; Garanzha, V. G.; Kulikova, L. K. Khim.-Farm. Zh. 1976, 10, 66; [Chem. Abstr. 1976, 84, 181597].

331. Gewald, K.; Roellig, H. Monatsh. Chem. 1983, 114, 999.

332. Simiti, I.; Zaharia, V.; Coman, M.; Demian, H. Arch. Pharm. (Weinheim) 1991, 324, 49.

333. Sangita; Pujari, H. K. Ind. J. Chem. 1979, 17B, 364.

334. Alper, H.; Stout, R. W. J. Heterocycl. Chem. 1973, 10, 5.

335. Krauze, A.; Popelis, J.; Duburs, G. Tetrahedron 1998, 54, 9161.

336. Balkan, A.; Ertan, M.; Burgemeister, T. Arch. Pharm. (Weinheim) 1992, 325, 499.

337. Liu, K.; Hsu, L. Arch. Pharm. (Weinheim) 1985, 318, 502.

338. Alper, H.; Lipshutz, B. H. J. Org. Chem. 1973, 38, 3743.

339. Koren, B.; Stanovnik, B.; Tisler, M. Heterocycles 1987, 26, 689.

340. Soliman, A. A. J. Chem. Eng. Data 1984, 29, 99. 
341. Bindal, V.; Sharma, B. R.; Pujari, H. K. Ind. J. Chem. 1986, $25 B, 354$.

342. Pal, R.; Handa, R. N.; Pujari, H. K. Ind. J. Chem. 1992, 31B, 771.

343. Rezessy, B.; Zubovics, Z.; Kovács, J.; Tóth, G. Tetrahedron 1999, 55, 5909.

344. Gewald, K.; Jaensch, H. J.; Galderon, O. Ger. (East) 1975,113,359; [Chem. Abstr. 1976, 84, 135647].

345. Joshi, M. G.; Wadodkar, K. N. Ind. J. Chem. 1981, 20B, 1090.

346. Kidwai, M.; Dave, B.; Bhushan, K. R. Chem. Pap. 2000, 54, 231.

347. Ulbricht, H. Pharmazie 1987, 42, 598.

348. Pei, W.; Li, S.; Nie, X.; Li, Y.; Pei, J.; Chen, B.; Wu, J.; Ye, X. Synthesis 1998, 1298.

349. Huang, W.; Pei, J.; Chen, B. Z.; Pei, W. W.; Ye, X. L. Tetrahedron 1996, 52, 10131.

350. Ward, A. M. Org. Synth. Coll. Vol. II 1943, 159.

351. Bredereck, H.; Gompper, R. Chem. Ber. 1954, 87, 726.

352. Rewald, M.; Schäfer, H.; Gewald, K. Monatsh. Chem. 1997, 128, 933.

353. Gewald, K.; Schäfer, H.; Bellmann, P.; Hain, U. J. Prakt. Chem. 1992, 334, 491.

354. Gewald, K.; Angermann, J.; Schäfer, H. Monatsh. Chem. 1996, 127, 313.

355. Hassaneen, H. M.; Elwan, N. M.; Abdelhadi, H. A.; Abdallah, T. A. Sulfur Lett. 1995, $18,121$.

356. Cho, J.; Kim, K.; J. Heterocycl. Chem. 1992, 29, 1433.

357. Hatta, T.; Mataka, S.; Tashiro, M.; Suzuki, H.; Numano, K. J. Heterocycl. Chem. 1991, $28,289$.

358. Reddy, N. J.; Bokadia, M.; Sharma, T.; Donnelly, J. A. J. Org. Chem. 1981, 46, 638.

359. Goerlitzer, K.; Engler, E. Arch. Pharm. (Weinheim) 1980, 313, 385.

360. Cozzi, P.; Carganico, G.; Pillan, A.; Branzoli, U. Ger. Offen. DE 1984, 3,324,069; [Chem. Abstr. 1984, 100, 174829].

361. Christensen, J. B.; Johannsen, I.; Bechgaard, K. J. Org. Chem. 1991, 56, 7055.

362. Venkov, A. P.; Vodenicharov, D. M. Synthesis 1990, 253.

363. Tupper, D. E.; Hotten, T. M.; Prowse, W. G. J. Heterocycl. Chem. 1996, 33, 1123.

364. Kihara, M.; Kashimoto, M.; Kobayashi, Y. Tetrahedron 1992, 48, 67.

365. Chang, M. Y.; Chang, B. R.; Tai, H. M.; Chang, N. C. Tetrahedron Lett. 2000, 41, 52.

366. Nishigaki, S.; Ichiba, M.; Sato, J.; Senga, K.; Noguchi, M.; Yoneda, F. Heterocycles 1978, $9,11$.

367. Sowell, J. W.; DeWitt, C. J. J. Heterocycl. Chem. 1973, 79, 66292.

368. Bayomi, S. M.; Al-Obaid, R. M.; Jado, A. I.; Loutfy, E. A. Ind. J. Chem. 1990, 29 B, 47.

369. Rival, Y.; Grassy, G.; Michel, G. Chem. Pharm. Bull. 1992, 40, 1170.

370. Mezentseva, M. V.; Kadushkin, A. V.; Alekseeva, L. M.; Sokolova, A. S.; Granik, V. G. Khim.Farm. Zh. 1991, 25, 19; [Chem. Abstr. 1992, 116, 106230].

371. Wang, X.; Wang, Z.; Lian, R. Huaxue Xuebao 1982, 40, 459; [Chem. Abstr. 1982, 97, 127334].

372. Fenner, H.; Meier, H. J.; Anschuetz, R. Arch. Pharm. (Weinheim) 1981, 314, 729.

373. Sarkis, G. Y.; Al-Azawe, S. J. Chem. Eng. Data 1973, 18, 102.

374. Tsubata, Y.; Suzuki, T.; Miyashi, T.; Yamashita, Y. J. Org. Chem. 1992, 57, 6749.

375. Aleksandrova, D. M.; Kolotova, L. I.; Distanov, B. G. Kratk. Tezisy-Vses. Soveshch. Probl. Mekh. Geteroliticheskikh Reakts. 1974, 107; [Chem. Abstr. 1976, 85, 122910]. 
376. Aleksandrova, D. M.; Kolotova, L. I.; Kheifets, L. Ya. Zh. Org. Khim. 1973, 9, 2107; [Chem. Abstr. 1974, 80, 36469].

377. Orlov, V. D.; Kotos, N. N. Vestn. Khar'k. Univ. 1991, 359, 69; [Chem. Abstr. 1993, 119, 72570].

378. Surender, E.; Reddy, R. B.; Reddy, P. B.; Chandramouli, G. V. P.; Reddy, Y. D. J. Ind. Chem. Soc. 1984, 61, 534.

379. Chattopadhyay, G.; Chakrabarty, M. Ind. J. Chem. 1990, $29 B, 1$.

380. Aloup, J.; Audisu, F.; Damour, D.; Genevois-Borella, A.; Jimonet, P.; Mignani, S. PCT Int. Appl. WO, 1995, 95 12,594; [Chem. Abstr. 1995, 123, 256766].

381. Batori, S.; Messmer, A. J. Heterocycl. Chem. 1990, 27, 1673.

382. Taran, S. G.; Ukrainets, I. V.; Sidorenko, L. V.; Gorokhova, O. V.; Jardat, N. A. Chem. Heterocycl. Compd. (N.Y.) 2000, 36, 944.

383. Temple, C.; Wheeler, G. P.; Comber, R. N.; Elliot, R. D.; Montgomery, J. A. J. Med. Chem. 1983, 26, 1614.

384. Correia, J. J. Org. Chem. 1973, 38, 3433.

385. Matzanke, N.; Loewe, W.; Perachon, S.; Sokoloff, P.; Schwartz, J. C.; Stark, H. Eur. J. Med. Chem. 1999, 34, 791.

386. Garcia Ruano, J. L.; Martinez, M. C.; Rodriguez, J. H.; Olefirowicz, E. M.; Eliel, E. L. J. Org. Chem. 1992, 57, 4215.

387. Kim, Y.; Mautner, H. G. J. Med. Chem. 1974, 17, 369.

388. Sakai, K.; Yoneda, N. Chem. Pharm. Bull. 1981, 29, 1554.

389. Ead, H. A.; Metwalli, N. H. Arch. Pharm. (Weinheim) 1990, 323, 57.

390. Ali, M. I.; Dawoud, A. F.; Soliman, A. A. J. Prakt. Chem. 1976, 318, 865.

391. Kim, D. C.; Yoo, K. H.; Shin, K. J. J. Heterocycl. Chem. 1997, 34, 57.

392. Rahman, L. K. A.; Scrowston, R. M. J. Chem. Soc., Perkin Trans. 1 1983, 2973.

393. Mashraqui, S. H.; Kellogg, R. M. Tetrahedron Lett. 1985, 26, 1457.

394. Lown, J. W.; Akhtar, M. H.; Dadson, W. M. J. Org. Chem. 1975, 40, 3363.

395. Taniguchi, H.; Isomura, K. Jpn. Kokai Tokkyo Koho JP, 1990, 02,204,485; [Chem. Abstr. 1991, $114,81888]$.

396. Guingant, A.; Renault, J. Bull. Soc. Chim. Fr. 1976, 291.

397. Dorneanu, M.; Carp, E.; Zugravescu, I. An. Stiint. Univ. 1974, 20, 35; [Chem. Abstr. 1975, 82, 125334].

398. Guingant, A.; Renault, J. C. R. Acad. Sci. Ser. C 1974, 297, 49; [Chem. Abstr. 1975, 82, 57634].

399. Mamedov, V. A.; Tsuboi, S.; Mustakimova, L. V.; Hamamoto, H.; Gubaidullin, A. T.; Litvinov, I. A.; Levin, Y. A. Chem. Heterocycl. Compd. (N. Y.) 2000, 36, 911.

400. Ganesh, T.; Kumar, Ch. H.; Krupadanam, G. L. D. Synth. Commun. 1999, 29, 2069.

401. Ogawa, K.; Terada, T.; Yamazaki, T.; Yamada, S.; Honna, T.; Ohta, S.; Okamoto, M. J. Chem. Soc., Perkin Trans. 1 1985, 2417.

402. Nakayama, J.; Motoyama, H.; Machida, H.; Shimomura, M. Heterocycles 1984, 22, 1527.

403. Brewer, A. D.; Davis, R. A. Ger. Offen. 1976, 2,527,639; [Chem. Abstr. 1976, 84, 150640]. 
404. Tomita, Y.; Kabashima, S.; Okawara, T.; Yamasaki, T.; Furukawa, M. J. Heterocycl. Chem. 1990, 27, 707.

405. Busby, R. E.; Dominey, T. W. J. Chem. Soc., Perkin Trans. 2 1980, 890.

406. Chupakin, O. K.; Sidorova, L. P.; Tarakhty, E. A.; Novikova, A. P.; Perova, N. M.; Vinogradov, V. A.; van Kinkel, M. F. PCT Int. Appl. WO 1997, 97 24,352; [Chem. Abstr. 1997, 127, 149164].

407. Sastry, C. V. R.; Rao, K. S.; Singh, P. P.; Rao, C. S.; Junnarkar, A. Y. Ind. J. Heterocycl. Chem. $1992,1,195$.

408. Molina, P.; Ferao, A.; Fresneda, P. M.; Lorenzo, A.; Tarraga, A. J. Heterocycl. Chem. 1983, 20, 381.

409. Kuz'menko, V. V.; Kuz'menko, T. A.; Pozharskii, A. F.; Kryshtalyuk, O. V. Khim. Geterotsikl. Soedin. 1990, 1689; [Chem. Abstr. 1991, 114, 207130].

410. Molina, P.; Arques, A.; Velasco, M.; Villalgordo, J. M. Heterocycles 1987, 26, 1323.

411. Novikova, A. P.; Perova, N. M.; Egorova, L. G.; Bragina, E. I. Khim. Geterotsikl. Soedin. 1991, 843; [Chem. Abstr. 1992, 116, 174115].

412. Ibrahim, Y. A.; Elwahy, A. H. M.; El-Fiky, A. E. M. Heteroat. Chem. 1994, 5, 321.

413. Kolos, N. N.; Orlov, V. D.; Slobodina, E. K.; Yur'eva, E. Yu.; Korshunov, S. P.; Zuong, V. T. Khim. Geterotsikl. Soedin. 1992, 267; [Chem. Abstr. 1992, 117, 233990].

414. Ilhan, E.; Ergenc, N.; Ulusoy, N.; Otuk-Sanis, G. Pharmazie 1996, 51, 123.

415. Molina, P.; Vilaplana, M. J. J. Chem. Res. (S) 1986, 70.

416. Awad, I. M. A.; Abdel-Rahman, A. E.; Bakite, E. A. J. Chem. Technol. Biotechnol. 1991, 51, 483.

417. Chande, M. S.; Karnik, B. M. J. Ind. Chem. Soc. 1990, 67, 782.

418. El-Khawass, E. M. J. Pharm. Sci. 1990, 4, 49.

419. Eisa, H. M. Mansoura J. Pharm. Sci. 1990, 6, 1; [Chem. Abstr. 1991, 114, 228874].

420. Kalyanam, N.; Manjunatha, S. G. Chem. Ind. (London) 1991, 319.

421. Becker, H. G. O.; Nagel, D.; Timpe, H. J. J. Prakt. Chem. 1973, 315, 1131.

422. Santagati, A.; Santagati, M.; Modica, M. Heterocycles 1993, 36, 1315.

423. Santagati, A.; Modica, M.; Santagati, M. J. Heterocycl. Chem. 1994, 31, 1141.

424. Liebscher, J.; Hassoun, A. J. Prakt. Chem. 1990, 332, 470.

425. Abdallah, S. O.; Hammouda, H. A.; Ali, F. A. Pharmazie 1986, 41, 101.

426. La Noce, T.; Crivellone, C. Gazz. Chim. Ital. 1975, 105, 1029.

427. El-Feky, S. A. H. Zhonghua Yaoxue Zazhi 1991, 43, 297; [Chem. Abstr. 1992, 116, 41398].

428. Orlov, V. D.; Yaremenko, F. G.; Lavrushin, V. F. Khim. Geterotsikl. Soedin. 1980, 1489; [Chem. Abstr. 1981, 95, 6925].

429. Kawabata, T.; Minami, T.; Hiyama, T. J. Org. Chem. 1992, 57, 1864.

430. Ueno, T.; Kitano, M. Jpn. Kokai Tokkyo Koho JP 1991, 03,279,356; [Chem. Abstr. 1992, 116, 255396].

431. Parcell, R. F.; Sanchez, J. P. J. Org. Chem. 1981, 46, 5055.

432. Cocco, M. T.; Congiu, C.; Onnis, V. J. Heterocycl. Chem. 1995, 32, 463. 
433. Cocco, M. T.; Congiu, C.; Onnis, V. J. Heterocycl. Chem. 1995, 32, 1679.

434. Fodor, L.; Szabo, J.; Bernath, G.; Sohár, P. Tetrahedron Lett. 1995, 36, 753.

435. Bartsch, H.; Erker, T. Sci. Pharm. 1989, 57, 325.

436. Csuzdi, E.; Pallagi, I.; Sziráki, I.; Sólyom, S. J. Prakt. Chem. 1998, 340, 472.

437. Carson, J. R.; Carmosin, R. J.; Vaught, J. L.; Gardocki, J. F.; Costanzo, M. J.; Raffa, R. B.; Almond, H. R.; J. Med. Chem. 1992, 35, 2855.

438. Behera, G. B.; Mishra, S. S.; Panda, D. S.; Sutar, S. J. Ind. Chem. Soc. 1983, 60, 465.

439. Sato, K.; Ohashi, M.; Aoki, E.; Murai, Y. J. Org. Chem. 1977, 42, 3713.

440. Reid, E. B.; Fortenbauch, R. B.; Patterson, H. R. J. Org. Chem. 1950, 15, 579.

441. Caplar, V.; Lisini, A.; Kajfez, F.; Kolbah, D.; Sunjic, V. J. Org. Chem. 1978, 43, 1355.

442. Gladiali, S.; Porcu, M. P.; Rosnati, V.; Saba, A.; Soccolini, F.; Selva, A. Gazz. Chim. Ital. 1977, 107, 293.

443. Auwers, K. V.; Ludewig, H.; Müller, A. Liebigs Ann. Chem. 1936, 526, 158.

444. Belrame, P.; Rosnati, V.; Sannicolo, F. Tetrahedron Lett. 1970, 4219.

445. Wameboldt, R. B.; Weiler, L. Tetrahedron Lett. 1971, 3413.

446. Ying, T.; Bao, W.; Zhang, Y.; Xu, W. Tetrahedron Lett. 1996, 37, 3885.

447. Ram, R. N.; Singh, L. Tetrahedron Lett. 1995, 36, 5401.

448. Ying, T.; Bao, W.; Zhang, Y. Synth. Commun. 1996, 26, 2905.

449. Krauser, S. F.; Watterson, A. C. J. Org. Chem. 1978, 43, 3400.

450. Guersoy, A.; Demirayak, S.; Capan, G.; Erol, K.; Vural, K. Eur. J. Med. Chem. 2000, 35, 359.

451. Petride, H.; Dalla, C. A.; Florea, C.; Caproiu, M. Rev. Roum. Chim. 1999, 44, 249.

452. Dubs, P.; Stuessi, R. Synthesis 1976, 696.

453. Terentiev, P. B.; Kost, A. N.; Lomakina, N. P.; Kartev, V. G. Org. Prep. Proced. Int. 1974, 6, 145.

454. Ried, W.; Kaiser, L. Liebigs Ann. Chem. 1975, 958.

455. Bredereck, H.; Gompper, R. Chem. Ber. 1954, 87, 700.

456. Purohit, N. V. Ind. J. Chem. 2001, 40B, 222.

457. Purohit, N. V.; Mukherjee, S. N. J. Ind. Chem. Soc. 1998, 75, 310.

458. Malamas, M. S.; McDevitt, R. E.; Adebayo, F. O. PCT Int. Appl. WO 1998, 99 58,518; [Chem. Abstr. 1999, 131, 351222].

459. Sarbagya, D. P.; Mazumdar, A. K. D.; Banerji, K. D. Natl. Acad. Sci. Lett. (India) 1979, 2, 219; [Chem. Abstr. 1980, 92, 146520].

460. Dikshit, D. K.; Singh, S.; Singh, M. M.; Kamboj, V. P. Ind. J. Chem. 1990, 29B, 954.

461. Hradil, P.; Hlavác, J.; Lemr, K. J. Heterocycl. Chem. 1999, 36, 141.

462. Spence, T. W. M.; Tennant, G. J. Chem. Soc. (C) 1971, 3712.

463. Monnier, K.; Schmitt, G.; Laude, B.; Mercier, M.; Kubicki, M. M.; Jannin, M. Can. J. Chem. 1995, 73, 181.

464. Ege, G.; Arnold, P.; Noronha, R. Liebigs Ann. Chem. 1979, 656.

465. Matthews, A. E.; Hodginson, W. R. Chem. Ber. 1882, 15, 2679.

466. Justoni, R. Gazz. Chim. Ital. 1939, 69, 378. 
467. Takehashi, K.; Nighizuka, T.; Jida, H. Synth. Commun. 1981, 11, 757.

468. Yasuda, M.; Oh-hata, T.; Shibata, I.; Baba, A.; Matsuda, H. J. Chem. Soc., Perkin Trans. 1 $1993,859$.

469. Saito, K.; Harada, K. Tetrahedron Lett. 1989, 30, 1651.

470. Florio, S.; Troisi, L.; Capriati, V. Tetrahedron Lett. 1998, 39, 7951.

471. Abad, A.; Agulló, C.; Arnó, M.; Seoane, F. Tetrahedron 1986, 42, 2429.

472. Mowry, D. T. Chem. Rev. 1948, 42, 189.

473. Koutek, B.; Pavlickova, L.; Soucek, M. Collect. Czech. Chem. Commun. 1973, 38, 3872.

474. Rodios, N. A.; Bojilova, A.; Terzis, A.; Raptopoulou, C. P. J. Heterocycl. Chem. 1994, $31,1129$.

475. Edwards, O. E.; Grieco, C. Can. J. Chem. 1974, 52, 3561.

476. Yakubovich, A. Y.; Bogolovskii, N. A.; Pravova, E. P.; Rozenhtein, S. M. Zh. Obshch. Khim. 1958, 28, 2288; [Chem. Abstr. 1961, 55, 13302].

477. Kobler, H.; Schuster, K. H.; Simchen, G. Justus Liebigs Ann. Chem. 1978, 1946.

478. Justoni, R.; Terruzi, M. Gazz. Chim. Ital. 1948, 78, 166.

479. Behringer, H.; Ruff, M.; Weidenmann, R. Chem. Ber. 1964, 97, 1737.

480. Galons, H.; Girardeau, J. F.; Combet-Farnoux, C. Bull. Soc. Chim. Fr. 1977, 936.

481. Campos, O.; Cook, J. M. J. Heterocycl. Chem. 1977, 14, 711.

482. Ramadas, S. R.; Padmanabhan, S. Ind. J. Chem. 1979, 17B, 195.

483. Gopalan, A.; Magnus, P. J. Am. Chem. Soc. 1980, 102, 1756.

484. Wick, A.; Frost, J.; Lardenois, P. Fr. Demande FR 1986, 2,566,775; [Chem. Abstr. 1986, 105, 133868].

485. Pinna, G. A.; Curzu, M. M.; Sechi, M.; Chelucci, G.; Maciocco, E. Farmaco 1999, 54, 542.

486. Chin, P.; Sammes, M. P. Tetrahedron 1990, 46, 3439.

487. Arai, S.; Nakayama, K.; Suzuki, Y.; Hatano, K.; Shioiri, T. Tetrahedron Lett. 1998, 39, 9739.

488. McIntosh, J. M.; Khalil, H. Can. J. Chem. 1978, 56, 2134.

489. Gewald, K. Chem. Ber. 1966, 99, 1002.

490. Harigaya, Y.; Yamamoto, T.; Okawara, M. Chem. Lett. 1974, 101.

491. Feng, X.; Lancelot, J.; Gillard, A.; Landelle, H.; Rault, S. J. Heterocycl. Chem. 1998, 35, 1313.

492. Abdelrazek, F. M.; Erian, A. W.; El-Torgoman, A. M. Chem. Ind. (London) 1988, 30.

493. Abdelrazek, F. M.; Erian, A. W.; Hilmy, K. M. H. Synthesis 1986, 74.

494. Abdelrazek, F. M. J. Prakt. Chem. 1990, 332, 479.

495. Abdelrazek, F. M.; Kandeel, Z. E.; Salah, A. M. Heteroat. Chem. 1995, 6, 77.

496. Temnikova, T. I.; Semenova, S. N.; Bondar, N. F. Zh. Org. Khim. 1973, 9, 1809; [Chem. Abstr. 1974, 80, 14797].

497. Abdelhamid, A. O.; Negm, A. M.; Abbas, I. M. J. Prakt. Chem. 1989, 331, 31.

498. Temnikova, T. I.; Sharanin, Y. A. Zh. Org. Khim. 1966, 2, 2018; [Chem. Abstr. 1967, 66, 75474].

499. Sherif, S. M. Unpublished results.

500. Elnagdi, M. H.; El-Ghamry, Kandeel, E.; Abdel-Rahman, A. H.; Al-Naggar, A.; Amer, S.; Riad, M. Gazz. Chim. Ital. 1997, 127, 791. 
501. Chiu, P.; Kan, L.; Fong, T.; Sammes, M. P. J. Chem. Res. (S) 1990, 44.

502. Zask, A. J. Org. Chem. 1992, 57, 4558.

503. Zask, A.; Nowicki, J. W.; Jirkovsky, I.; Engen, D. V. Tetrahedron Lett. 1993, 34, 2719.

504. Ehrenfreund, J.; Kristiansen, O.; Kristinsson, H.; Wasitschatka, R.; Waespe, H. R.; Pascual, A. Ger. Offen. DE 1990, 4,011,740; [Chem. Abstr. 1991, 114, 102065].

505. Larcheveque, M.; Perriot, P.; Petit, Y. Synthesis 1983, 297.

506. Zoorob, H. H.; Ismail, M. A.; Strekowski, L. J. Heterocycl. Chem. 2001, 38, 359.

507. Bundy, G. L.; Schwartz, T. M.; Palmer, J. R.; Banitt, L. S.; Watt, W. J. Heterocycl. Chem. 2000 , $37,1471$.

508. Jacobsen, E. J.; McCall, J. M.; Ayer, D. E.; vanDoornik, F. J.; Palmer, J. R.; Belonga, K. L.; Braughler, J. M.; Hall, E. D.; Houser, D. J.; Krook, M. A.; Runge, T. A. J. Med. Chem. 1990, $33,1145$.

509. Erian, A. W. Synth. Commun. 1998, 28, 3549.

510. Garcia, M. A.; Herrera, F. A.; Molero, V. D.; Hanack, M.; Subramanian, L. R. Synthesis 1992, 1053.

511. Bojilova, A.; Trendafilova, A.; Ivanov, C. Tetrahedron 1993, 49, 2275.

512. Widam, O. Ber. Dtsch. Chem. Ges. 1918, 51, 533.

513. Widam, O. Ber. Dtsch. Chem. Ges. 1918, 51, 907.

514. McCoy, L. L. J. Org. Chem. 1960, 25, 2078.

515. McCoy, L. L. J. Org. Chem. 1964, 29, 240.

516. Jonczyk, A.; Makosza, M. Synthesis 1976, 387.

517. Fraisse, R.; Guitard, M. Bull. Soc. Chim. Fr. 1961, 200.

518. Makosza, M.; Kwast, A. Tetrahedron 1991, 47, 5001.

519. Kosugi, M.; Arai, H.; Yoshino, A.; Migita, T. Chem. Lett. 1978, 795.

520. Pri-Bar, I.; Pearlman, P. S.; Stille, J. K. J. Org. Chem. 1983, 48, 4629.

521. Yano, K.; Hatta, Y.; Baba, A.; Matsuda, H. Synthesis 1992, 693.

522. Yasuda, M.; Oh-hata, T.; Shibata, I.; Baba, A.; Matsuda, H.; Sonoda, N. Bull. Chem. Soc. Jpn. 1995, 68, 1180.

523. Koga, Y.; Kusama, H.; Narasaka, K. Bull. Chem. Soc. Jpn. 1998, 71, 475.

524. Chatt, J.; Dilworth, J. R.; Leigh, G. J. J. Chem. Soc., Dalton Trans. 1973, 612.

525. Stetin, C.; De Jeso, B.; Pommier, J. C. J. Org. Chem. 1985, 50, 3863.

526. Nagafuji, P.; Cushman, M. J. Org. Chem. 1996, 61, 4999.

527. Yasuda, M.; Oh-hata, T.; Shibata, I.; Baba, A.; Matsuda, H. J. Chem. Soc., Perkin Trans. 1 1993, 859.

528. Yasuda, M.; Katoh, Y.; Shibata, I.; Baba, A.; Matsuda, H.; Sonoda N. J. Org. Chem. 1994, 59, 4386.

529. Yasuda, M.; Morimoto, J.; Shibata, I.; Baba, A. Tetrahedron Lett. 1997, 38, 3265.

530. Yasuda, M.; Tsuji, S.; Shibata, I.; Baba, A. J. Org. Chem. 1997, 62, 8282.

531. De Kimpe, N.; Yao, Z. P.; Schamp, N. Tetrahedron Lett. 1986, 27, 1707.

532. Narayanan, N.; Balasubramanian, T. R. J. Organomet. Chem. 1992, 423, 361. 
533. Kobayashi, T.; Nitta, M. Chem. Lett. 1985, 1459.

534. Nitta, M.; Kobayashi, T. Chem. Lett. 1986, 463.

535. Iino, Y.; Kobayashi, T.; Nitta, M. Heterocycles 1986, 24, 2437.

536. Kirschke, K.; Costisella, B. J. Prakt. Chem. 1990, 332, 143.

537. Kirschke, K.; Möller, A.; Schmitz, E. J. Prakt. Chem. 1985, 327, 893.

538. Groundwater, P. W.; Munawar, M. A. J. Chem. Res. (S) 1996, 256.

539. Baumgarten, H. E.; Creger, P. L.; Villars, C. E. J. Am. Chem. Soc. 1958, 80, 6609.

540. Mann, J. Tetrahedron 1986, 42, 4611.

541. Noyori, R.; Hayakawa, Y. Tetrahedron 1985, 41, 5879.

542. Kosugi, M.; Takamo, I.; Hoshino, I.; Migita, T. J. Chem. Soc., Chem. Commun. 1983, 1031.

543. Angermann, J.; Homann, K.; Reissig, H.; Zimmer, R. Synlett 1995, 1014.

544. Han, Y.; Huang, Y. Tetrahedron Lett. 1998, 39, 7751.

545. Katritzky, A. R.; Fali, C. N.; Li, J. J. Org. Chem. 1997, 62, 4148.

546. Katritzky, A. R.; Li, J. J. Org. Chem. 1996, 61, 1624.

547. Katritzky, A. R.; Li, J. J. Org. Chem. 1995, 60, 638.

548. Katritzky, A. R.; Li, J.; Stevens, C. V. J. Org. Chem. 1995, 60, 3401.

549. Shibata, I.; Yamasaki, H.; Baba, A.; Matsuda, H. Synlett 1990, 490.

550. Shi, M.; Itoh, N.; Masaki, Y. J. Chem. Res. (S) 1995, 46, (M), 410.

551. Kel'in, A. V.; Kozyrkov, Y. Y. Synthesis 1998, 729.

552. Kel'in, A. V.; Kulinkovich, O. G. Synthesis 1996, 330.

553. Bansal, R. K.; Sethi, K. Bull. Chem. Soc. Jpn. 1980, 53, 1147.

554. Tomisawa, K.; Kameo, K.; Goi, M.; Sota, K. Chem. Pharm. Bull. 1984, 32, 3066.

555. Venturella, P.; Bellino, A.; Piozzi, F.; Marino, M. L. Heterocycles 1976, 4, 1089.

556. Chan, T. H.; Li, C. J.; Wei, Z. Y. J. Chem. Soc., Chem. Commun. 1990, 505.

557. Zhang, Y.; Sun, P. Huaxue Tongbao 1997, 53; [Chem. Abstr. 1997, 127, 95063].

558. Maruoka, K.; Hashimoto, S.; Kitagawa, Y.; Yamamoto, H.; Nozaki, H. Bull. Chem. Soc. Jpn. 1980, 53, 3301.

559. Matsubara, S.; Tsuboniwa, N.; Morizawa, K.; Oshima, K.; Nozaki, H. Bull. Chem. Soc. Jpn. 1984, 57, 3245.

560. Tsuboniwa, N.; Matsubara, S.; Morizawa, Y.; Oshima, K.; Nozaki, H. Tetrahedron Lett. 1984, $25,2569$.

561. Lin, R.; Chen, L.; Zhang, Y. Youji Huaxue 1990, 10, 454; [Chem. Abstr. 1991, 114, 81161].

562. Kagayama, A.; Igarashi, K.; Shiina, I.; Mukaiyama, T. Bull. Chem. Soc. Jpn. 2000, 73, 2579.

563. Orsini, F. J. Org. Chem. 1997, 62, 1159.

564. Molander, G. A.; Etter, J. B.; Harring, L. S.; Thorel, P. J. J. Am. Chem. Soc. 1991, 113, 8036.

565. Chan, T. H.; Li, C. J.; Lee, M. C.; Wei, Z. Y. Can. J. Chem. 1994, 72, 1181.

566. Wessjohann, L.; Wid, H. Synthesis 1997, 512.

567. Ito, Y.; Asada, M.; Yonezawa, K.; Saegusa, T. Synth. Commun. 1974, 4, 87.

568. Klein, H. F.; Karsch, H. H. Chem. Ber. 1975, 108, 944.

569. Yu, Y.; Lin, R.; Zhang, Y. Tetrahedron Lett. 1993, 34, 4547. 
570. Fukuzawa, S.; Tsuruta, T.; Fujinami, T.; Sakai, S. J. Chem. Soc., Perkin Trans. 1 1987, 1473.

571. Zhang, Y.; Liu, T.; Lin, R. Synth. Commun. 1988, 18, 2003.

572. Arime, T.; Takahashi, H.; Kobayashi, S.; Yamaguchi, S.; Mori, N. Synth. Commun. 1995, 25, 389.

573. Fan, X.; Zhang, Y. J. Chem. Res. (S) 2001, 104.

574. Xie, L.; Huang, Z.; Huang, X. Huaxue Shiji 1990, 12, 257; [Chem. Abstr. 1991, 114, 184916].

575. Lin, R.; Yu, Y.; Zhang, Y. Synth. Commun. 1993, 23, 271.

576. Imamoto, T.; Kusumoto, T.; Yokoyama, M. Tetrahedron Lett. 1983, 24, 5233.

577. Zhang, L.; Huang, Y. J. Organomet. Chem. 1993, 454, 101.

578. Huang, Y. Z.; Zhang, L. J.; Chen, C.; Guo, G. Z. J. Organomet. Chem. 1991, 412, 47.

579. Elnagdi, M. H.; Elmoghayar, M. R. H.; Elgemeie, G. E. H. Synthesis 1984, 1.

580. Obregia, A. Justus Liebigs Ann. Chem. 1891, 266, 324.

581. Vladesco, M. D. Bull. Soc. Chim. Fr. 1891, 6, 807.

582. Justoni, R. Gazz. Chim. Ital. 1939, 69, 79.

583. Jimura, F. Nippon Kagaku Zasshi 1957, 78, 48; [Chem. Abstr. 1959, 53, 5185].

584. Richard, D.; Cantacuzene, J. Bull. Soc. Chim. Fr. 1969, 628.

585. Justoni, R.; Terruzi, M. Gazz. Chim. Ital. 1950, 80, 259.

586. Kuehne, M. E. J. Org. Chem. 1970, 35, 171.

587. Blount, J. F.; Coffen, D. L.; Katonak, D. A. J. Org. Chem. 1978, 43, 3821.

588. Kohler, E. P.; Brown, F. W. J. Am. Chem. Soc. 1933, 55, 4299.

589. Farag, A. M.; Dawood, K. M.; Kandeel, Z. E. Tetrahedron 1997, 53, 161.

590. Farag, A. M.; Dawood, K. M.; Kandeel, Z. E. Tetrahedron 1996, 52, 7893.

591. Erian, A. W.; Sherif, S. M. Tetrahedron 1999, 55, 7957.

592. Singh, S. P.; Sehgal, S.; Singh, L.; Dhavan, S. N. Ind. J. Chem. 1987, 26B, 154.

593. Ali, S. M.; Clarke, D.; Cliff, G. R.; Morrison, G. A. J. Chem. Res. (S) 1981, 234.

594. Mohareb, R. M.; Shams, H. Z.; Elnagdi, M. H. Gazz. Chim. Ital. 1992, 122, 41.

595. Kapoor, R. P.; Sharma, V. P.; Singh, O. V.; Garg, C. P. Ind. J. Chem. 1991, 30B, 1152.

596. Xian, H.; Pi, J. Synth. Commun. 1990, 20, 2291.

597. Ren, Q.; Huang, W.; Lu, Y.; Yin, Y.; He, B. Huaxue Xuebao 1990, 48, 622; [Chem. Abstr. 1991, 114, 42167].

598. Din, Y.; Fan, A.; Zhang, Z. Yingyong Huaxue 1997, 14, 113; [Chem. Abstr. 1997, 127, 161651$].$

599. Xu, C.; Chen, Z. Tetrahedron Lett. 1991, 32, 2933.

600. Boyer, J. H.; Straw, D. J. Am. Chem. Soc. 1953, 75, 1642.

601. Pasquet, G.; Doucherot, D.; Pilgrim, W. R.; Wright, B. Tetrahedron Lett. 1980, 931.

602. Tennyson, R.; Romo, D. J. Org. Chem. 2000, 65, 7248.

603. Boyer, J. H.; Straw, D. J. Am. Chem. Soc. 1952, 74, 4506.

604. Mamedov, V. A.; Gubaidullin, A. T.; Litvinov, I. A.; Tsuboi, S. Heterocycles 2000, 52, 1385.

605. Cassar, L.; Chiusoli, G. P.; Guerrieri, E. Synthesis 1973, 509.

606. Knowles, R. N. U.S. Pat., 1972, 3,636,082,; [Chem. Abstr. 1972, 76, 85569].

607. Hidai, M.; Kokura, M.; Uchida, Y. J. Organomet. Chem. 1973, 52, 431. 
608. Heck, R. F.; Nolley, J. P. J. Org. Chem. 1972, 37, 2320.

609. Stille, J. K.; Wong, P. K. J. Org. Chem. 1975, 40, 532.

610. Lichtenthaler, F. W. Chem. Rev. 1961, 61, 607.

611. Borowitz, I. J.; Firstenberg, S.; Borowitz, G. B.; Schuessler, D. J. Am. Chem. Soc. 1972, 94, 1623.

612. Honig, M. L.; Sheer, M. L. J. Org. Chem. 1973, 38, 3434.

613. Nikonorov, K. V.; DeKlesova, I. D.; Gurylev, E. A.; Kudrina, M. A.; Nikonenko, V. A.; Iraidova, I. S.; Anisimova, N. N. Zh. Obshch. Khim. 1976, 46, 560; [Chem. Abstr. 1976, 85, 5795].

614. Chopard, P. A.; Clark, V. M.; Hudson, R. F.; Kirby, A. J. Tetrahedron 1965, 21, 1961.

615. Gaydou, E. M.; Buono, G.; Fréze, R. Bull. Soc. Chim. Fr. 1973, 2284.

616. Gaydou, E. M.; Bianchini, J. B. Can. J. Chem. 1976, 54, 3626.

617. Kienzle, F.; Rosen, P. Helv. Chim. Acta 1979, 62, 442.

618. Oohashi, K.; Banno, T.; Umeno, M. Jpn. Kokai Tokkyo Koho JP 1995, 07 10,893; [Chem. Abstr. 1995, 123, 171388].

619. Banno, T.; Oohashi, K.; Yokota, T.; Mori, K. Jpn. Kokai Tokkyo Koho JP 1995, 07 82,283; [Chem. Abstr. 1995, 123, 199689].

620. Krylova, T. O.; Kolomnikova, G. D.; Petrovskii, P. V.; Gololobov, Yu. G. Izv. Akad. Nauk, Ser. Khim. 1994, 1641; [Chem. Abstr. 1995, 123, 112159].

621. Kamiya, N.; Tanmatu, H.; Ishii, Y. Chem. Lett. 1992, 293.

622. Katritzky, A. R.; Pilarski, B.; Johnson, J. W. Org. Prep. Proced. Int. 1990, 22, 209.

623. Bianchini, J. P.; Gaydou, E. M. C. R. Hebd. Seances Acad. Sci., Ser. C 1975, 280, 1521; [Chem. Abstr. 1975, 83, 179214].

624. Allied, Corp. Jpn. Kokai Tokkyo Koho JP 1983, 58,128,394; [Chem. Abstr. 1984, 100, 6849].

625. Asinger, F.; Schmitz, M. K. Monatsh. Chem. 1982, 113, 1191.

626. Pfeiffer, W. D.; Bulka, E. Ger. (East) DD 1990, 281,582; [Chem. Abstr. 1991, 114, 185571].

627. Domasevich, K. V. Zh. Obshch. Khim. 1995, 65, 1405; [Chem. Abstr. 1996, 124, 176348].

628. Hervavi, M. M.; Bakavoli, M. J. Chem. Soc. Pak. 1995, 17, 118.

629. Wolf, D.; Bulka, E. Chem.-ztg. 1991, 115, 361.

630. Bilinski, S.; Bielak, L.; Chmielewski, J.; Marcewicz. R. B.; Musik, I. Acta Pol. Pharm. 1989, 46, 343; [Chem. Abstr. 1991, 114, 6379].

631. Ganjian, I. J. Heterocycl. Chem. 1990, 27, 2037.

632. Ganjian, I.; Lalezari, I. J. Heterocycl. Chem. 1985, 22, 857.

633. Lalezari, I.; Shafiee, A.; Yalpani, M. J. Org. Chem. 1973, 38, 338.

634. Wang, L.; Zhang, Y. J. Chem. Res. (S) 1998, 598.

635. Xian, H.; Xu, X. Synth. Commun. 1998, 28, 807.

636. Bao, W. L.; Zhang, Y. M. Synlett 1996, 1187.

637. Sharanin, Y. A.; Dyachenko, V. D.; Turov, A. V. Zh. Obshch. Khim. 1990, 60, 2750; [Chem. Abstr. 1991, 115, 49335]. 
638. Mortikov, V. Y.; Litvinov, V. P.; Shestopalov, A. M.; Sharanin, Y. A.; Apenova, E. E.; Galegov, G. A.; Abdulaev, I. I.; Asadullaev, T. B.; Abdullaev, F. I. Khim.-Farm. Zh. 1991, 25, 41; [Chem. Abstr. 1991, 115, 114383].

639. Pfeiffer, W. D.; Bulka, E.; Liskow, R. Ger. (East) DD 1990, 280,761; [Chem. Abstr. 1991, 114, 62102].

640. Zinic, M.; Stromar, M.; Malnar, M.; Kolbah, D. Croat. Chem. Acta 1974, 46, 45.

641. Karabatsos, G. J.; Taller, R. A. Tetrahedron 1968, 24, 3347.

642. Berlin, K. D.; Rengaraju, S. J. Org. Chem. 1971, 36, 2912.

643. Wolkowski, Z. W. Tetrahedron Lett. 1971, 825.

645. Buron, C.; El-Kaim, L.; Uslu, A. Tetrahedron Lett. 1997, 38, 8027.

646. Dines, M.; Scheinbaum, M. L. Tetrahedron Lett. 1969, 4817.

647. Tahdi, A.; Titouani, S. L.; Soufiaoui, M. Tetrahedron 1998, 54, 65.

648. Jones, R. C. F.; Martin, J. N.; Smith, P. Synlett 2000, 7, 967.

649. Mohareb, R. M.; Sherif, S. M.; Shams, H. Z.; El-Torgoman, A. M. Z. Naturforsch. 1990, 45b, 1067.

650. Perti, O. N.; Chandra, S.; Singhal, G. C. Ind. J. Chem. 1967, 5, 622.

651. Levin, N.; Hartung, W. H. J. Org. Chem. 1942, 7, 408.

652. Rheinboldt, H.; Schmitz-Dumont, O. Liebigs Ann. 1925, 444, 113.

653. Noyori, R.; Hayakawa, Y. Org. React. 1983, 29, 163.

654. Ho, T. L.; Wong, C. Synth. Commun. 1973, 3, 237.

655. Olah, G. A.; Arvanaghi, M.; VanKar, Y. D. J. Org. Chem. 1980, 45, 3531.

656. Ono, A.; Fujimoto, E.; Ueno, M. Synthesis 1986, 570.

657. Renso, M.; Mottadelli, S.; Albanese, D. Synth. Commun. 1993, 23, 1385.

658. Akane, N.; Kanagawa, Y.; Nishiyama, Y.; Ishi, Y. Chem. Lett. 1992, 12, 2431.

659. Mandal, A. K.; Nijasure, A. M. Synlett 1990, 554.

660. Osuka, A.; Suzuki, H. Chem. Lett. 1983, 119.

661. Engman, L.; Cava, M. P. J. Org. Chem. 1982, 47, 3946.

662. Perez, D.; Greenspoon, N.; Keinan, E. J. Org. Chem. 1987, 52, 5570.

663. Sarma, J. C.; Bobaruah, M.; Sharma, R. P. Tetrahedron Lett. 1985, 26, 4657.

664. Seshadri, R.; Pegg, W. J.; Isreal, M. J. Org. Chem. 1981, 46, 2596.

665. Ono, A.; Fujimoto, E.; Ueno, M. Synth. Commun. 1986, 16, 653.

666. Fuji, K.; Node, M.; Kawabata, T.; Fujimoto, M. J. Chem. Soc., Perkin Trans. 1 1987, 1043.

667. Borah, H.; Boruah, R. C.; Sandhu, J. S. J. Chem. Soc., Chem. Commun. 1991, 154.

668. Ono, A.; Kamimura, J.; Suzuki, N. Synthesis 1987, 406.

669. Chung, S. K.; Hu, Q. Y. Synth. Commun. 1982, 12, 261.

670. Kim, S.; Kim, Y. J.; Ahn, K. H. Tetrahedron Lett. 1983, 24, 3369.

671. Denis, J. N.; Krief, A. Tetrahedron Lett. 1981, 22, 1431.

672. Luh, T. Y.; Lai, C. H.; Lei, K. H.; Tam, S. W. J. Org. Chem. 1979, 44, 641.

673. Alper, H.; Pattee, L. J. Org. Chem. 1979, 44, 2568.

674. Shen, Z.; Zhang, J.; Zou, H.; Yang, M. Tetrahedron Lett. 1997, 38, 2733. 
675. Ramón, D. J.; Yus, M. Tetrahedron 1998, 54, 5651.

676. Li, C. L.; Harpp, D. N. Tetrahedron Lett. 1991, 32, 1545.

677. Schultz, E. K. V.; Happ, D. N. Synthesis 1998, 1137.

678. Dorrestijin, E.; Hemmink, S.; Hulstman, G.; Monnier, L.; van Scheppingen, W.; Mulder, P. Eur. J. Org. Chem. 1999, 607.

679. Brown, H. C.; Pai, G. G. J. Org. Chem. 1985, 50, 1384.

680. Brown, H. C. J. Org. Chem. 1988, 53, 2918.

681. Brown, H. C.; Srebnik, M.; Ramachandran, P. V. J. Org. Chem. 1989, 54, 1577.

682. Gong, B.; Brown, H. C. Chirality 1995, 7, 103.

683. Tatsumi, K.; Arima, N.; Yamato, C.; Yoshimura, H.; Tsukamoto, H. Chem. Pharm. Bull. 1970, $18,1254$.

684. Ballini, R.; Giovanna, B.; Frullanti, B.; Maggi, R.; Sartori, G.; Schroer, F. Tetrahedron Lett. 1998, 39, 1615.

685. Puigianer, C.; Vidal-Ferran, A.; Moyano, A.; Pericàs, M. A.; Riera, A. J. Org. Chem. 1999, 64, 7902.

686. Singh, V. K. Synthesis 1992, 605.

687. Pinho, P.; Guijarro, D.; Anderrson, P. G. Tetrahedron 1998, 54, 7897.

688. Salunkhe, A. M.; Burkhardi, E. R. Tetrahedron Lett. 1997, 38, 1523.

689. Zaidlewicz, M.; Chechlowska, A.; Prewysz-Kwinto, A.; Wojtczak, A. Heterocycles 2001, 55, 569.

690. Brown, H. C.; Chandrasekharan, J.; Ramachandran, P. V. J. Am. Chem. Soc. 1988, 110, 1539.

691. Brown, H. C.; Ramachandran, P. V.; Chandrasekharan, J. Heteroat. Chem. 1995, 6, 117.

692. Ren, P.; Jin, Q.; Yao, Z. Synth. Commun. 1997, 27, 2577.

693. Vedejs, E.; Duncan, S. M.; Haight, A. R. J. Org. Chem. 1993, 58, 3046.

694. Shibata, I.; Nakamura, K.; Baba, A.; Matsuda, H. Tetrahedron Lett. 1990, 33, 6381.

695. Castaing, M. D.; Millard, B.; Rahm, A. J. Organomet. Chem. 1985, 287, 49.

696. Sucrow, W.; Fehlauer, A.; Sandmann, U. Z. Naturforsch. 1977, 32b, 1072.

697. Bergman, J.; Bäckvall, J. E. Tetrahedron 1975, 31, 2063.

698. Hong, Y.; Gao, Y.; Nie, X.; Zepp, C. M. Tetrahedron Lett. 1994, 35, 6631.

699. Tongi, A.; Venanzi, L. M. Angew. Chem., Int. Ed. Engl. 1994, 33, 497.

700. Wallbaum, S.; Martens, J. Tetrahedron: Asymmetry 1992, 3, 1475.

701. Corey, E. J.; Link, J. O.; Bakshi, R. K. Tetrahedron Lett. 1992, 33, 7107.

702. Hageman, H. J.; Oosterhoff, P.; Overeem, T.; Verbeek, J. J. Photochem. Photobiol. 1997, 110A, 17.

703. Dhavale, D. D.; Mali, V. P.; Sudrik, S. G.; Sonawane, H. R. Tetrahedron 1997, 53, 16789.

704. Ballester, M. Chem. Rev. 1955, 55, 283.

705. Okano, T.; Hayashi, T.; Kiji, J. Bull. Chem. Soc. Jpn. 1994, 67, 2339.

706. Myrobh, B.; Ila, H.; Junjappa, H. Synthesis 1991, 126.

707. Adapa, S. R.; Pardhasaradhi, M. Ind. J. Chem. 1988, 27B, 84.

708. Purohit, P. C.; Sanawane, H. R. Tetrahedron 1981, 37, 873. 
709. Satoy, T.; Mizu, Y.; Hayashi, Y.; Yamakawa, K. Tetrahedron Lett. 1994, 35, 133.

710. Sonawane, H. R.; Buller, N. S.; Ahuja, J. R.; Kulkami, D. G. Tetrahedron: Asymmetry 1992, 3, 163.

711. Satyanarayana, N.; Periasamy, M. Tetrahedron Lett. 1987, 28, 2633.

712. Sonawane, H. R.; Bellur, N. S.; Kulkarni, D. G.; Ayyangar, N. R. Tetrahedron 1994, 50, 1243.

713. Sonawane, H. R.; Bellur, N. S.; Nazeruddin, G. M. Tetrahedron 1995, 51, 11281.

714. Kajigaeshi, S.; Kakinami, T.; Moriwaki, M.; Fujisaki, S.; Maeno, K.; Okamoto, T. Synthesis 1988, 545.

715. Bergmark, W. R. Chem. Commun. 1978, 61.

716. Barba, F.; De la Fuente, J. L. Tetrahedron Lett. 1992, 33, 3911.

717. Barba, F.; Velasco, M. D.; Guirado, A. Electrochim. Acta 1983, 28, 259.

718. Barba, F.; Velasco, M. D.; López, M. I.; Zapata, A.; Aldaz, A. J. Chem. Res. (S) 1988, 44.

719. Barba, F.; Velasco, M. D.; Guirado, A. Synthesis 1981, 625.

720. Fry, A. J.; Lefor, A. T. J. Org. Chem. 1979, 44, 1270.

721. Fry, A. J.; Guinsburg, G. S. J. Am. Chem. Soc. 1979, 101, 3928.

722. Barba, F.; Velasco, M. D.; Guirado, A. J. Heterocycl. Chem. 1982, 19, 669.

723. Durandetti, M.; Nédélec, J.; Périchon, J. J. Org. Chem. 1996, 61, 1748.

724. Kumar, P.; Kumar, D.; Vijayaraghavan, R.; Gupta, S. D. Ind. J. Pharmacol. 1997, 29, 238.

725. Husain, K.; Kumar, P. Ind. J. Med. Res. 1991, 94, 76.

726. de Lima, J. G.; Perrissin, M.; Chantegrel, J.; Luu-Duc, C.; Rousseau, A.; Narcisse, G. Arzneim.Forsch. 1994, 44, 831; [Chem. Abstr. 1995, 122, 150882].

727. Kato, K.; Kawamura, M.; Itsuda, H.; Kanazawa, T. Jpn. Kokai Tokkyo Koho JP 1986, 61 97,239; [Chem. Abstr. 1986, 105, 226049].

728. Camaggi, G.; Filippini, L.; Gusmeroli, M.; Riva, R.; Zanardi, G.; Garavaglia, V.; Mirenna, L. Eur. Pat. Appl. EP 1993, 554,956; [Chem. Abstr. 1994, 120, 8586].

729. Zask, A.; Jirkovsky, I. L. U.S. US 1993, 5,236,941; [Chem. Abstr. 1994, 120, 8587].

730. Allen, R. C.; Anderon, V. B. Ger. Offen. 1974, 2,407,671; [Chem. Abstr. 1975, 82, 4124].

731. Jakobi, H.; Ort, O.; Schaper, W.; Braun, R.; Krautstrunk, G.; Maerkl, M.; Stark, H.; Sanft, U.; Thoenessen, M.; Kern, M.; Bonin, W. Ger. Offen. DE 1998, 19,647,317; [Chem. Abstr. 1998, 129, 41145].

(C) 2003 by MDPI (http://www.mdpi.org). Reproduction is permitted for noncommercial purposes. 